Prepared in cooperation with the Federal Emergency Management Agency

\title{
Documentation and Hydrologic Analysis of Hurricane Sandy in New Jersey, October 29-30, 2012
}

Scientific Investigations Re,port 2015-5085

Version 1.1, December 2015

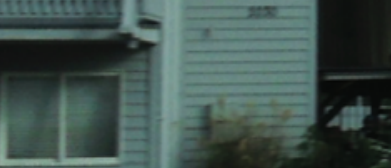

U.S. Department of the Interior U.S. Geological Survey 
Cover:

Bottom photo: Seaside Heights, New Jersey, November 4, 2012. (Photo by: Andrew Ebner, U.S. Geological Survey) Lower right photo: Long Beach Island, New Jersey, November 6, 2012. (Photo by: Andrew Ebner, U.S. Geological Survey) Right middle photo: Seaside Heights, New Jersey, November 4, 2012. (Photo by: Andrew Ebner, U.S. Geological Survey) Right upper middle photo: Long Beach Island, New Jersey, November 6, 2012. (Photo by: Andrew Ebner, U.S. Geological Survey) Upper photo: Union Beach, New Jersey, New Jersey, November 4, 2012. (Photo by: Carrie Huitger, U.S. Geological Survey) 


\section{Documentation and Hydrologic Analysis of Hurricane Sandy in New Jersey, October 29-30, 2012}

By Thomas P. Suro, Anna Deetz, and Paul Hearn

Prepared in cooperation with the

Federal Emergency Management Agency

Scientific Investigations Report 2016-5085

Version 1.1, December 2016 


\title{
U.S. Department of the Interior SALLY JEWELL, Secretary
}

\section{U.S. Geological Survey Suzette M. Kimball, Director}

\author{
U.S. Geological Survey, Reston, Virginia: 2016 \\ Revised: December 2016 (ver. 1.1)
}

For more information on the USGS - the Federal source for science about the Earth, its natural and living resources, natural hazards, and the environment-visit http://www.usgs.gov or call 1-888-ASK-USGS.

For an overview of USGS information products, including maps, imagery, and publications, visit http://store.usgs.gov.

Any use of trade, firm, or product names is for descriptive purposes only and does not imply endorsement by the U.S. Government.

Although this information product, for the most part, is in the public domain, it also may contain copyrighted materials as noted in the text. Permission to reproduce copyrighted items must be secured from the copyright owner.

Suggested citation:

Suro, T.P., Deetz, Anna, and Hearn, Paul, 2016, Documentation and hydrologic analysis of Hurricane Sandy in New Jersey, October 29-30, 2012 (ver. 1.1, December 2016): U.S. Geological Survey Scientific Investigations Report 2016-5085, 73 p., http://dx.doi.org/10.3133/sir20165085.

ISSN 2328-0328 (online) 


\section{Acknowledgments}

The authors would like to thank Scott Duell, Robert Schaefer, Alan Springett, Andrew Martin, and the entire Federal Emergency Management Agency (FEMA) Region II mitigation team for their support in the documentation of the flooding and associated damages presented in this report. The authors would also like to thank the Risk Assessment, Mapping, and Planning Partners team for providing coastal flood frequency data; Gene Longenecker and FEMA Region IV for providing inundation mapping data; Joseph Ruggeri and the New Jersey Department of Environmental Protection personnel for technical support; Robert Mason, Harry Jenter, and the U.S. Geological Survey (USGS) Office of Surface Water, Chris A. Smith, David Lairson, Dan Stephens, Kerry Caslow, Andrew Knaak, Jim Stull, and the USGS Georgia Water Science Center personnel for their help with data collection and analysis; Chad J. Ostheimer, Crystal L. Hammer, Carrie A. Huitger, Mike R. Brady, Branden L. VonIns, Jon D. Lageman, Andrew D. Ebner, Sean J. Brown, and the USGS Ohio Water Science Center personnel for their help with data collection and analysis; Bryce McClenney, Terry Middleton, David Stillwell, and Eric Rudisill from the USGS North Carolina Water Science Center for their help with data collection and analysis; Marie Peppler, Gary Latzke, and the USGS Wisconsin Internet Mapping team for data delivery through the Hurricane Sandy mapper; Ami Rahav for help with HAZUS analysis; Michael Lee of the USGS Texas Water Science Center for assistance with spectral analysis of wave data; and Robert Reiser of the USGS New Jersey Water Science Center for initial post storm support and coordination. The authors also thank Heidi Hoppe, Jason Shvanda, and the all New Jersey Hydrologic Data Assessment Program hydrologists and hydrologic technicians for their hard work and dedication before and after this major storm to collect and analyze the data used in this report and provided online through the National Water Information System: Robert Atkinson, Karl Braun, Patrick Bowen, Vincent Brown, Jerilyn Collenburg, Richard Edwards, Sarina Howell, Michal Niemoczynski, Brian Painter, Charlie Shivers, John Trainor, Aric Vanselous, and Andrew Watson. 



\section{Contents}

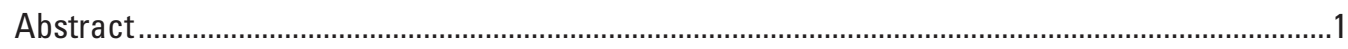

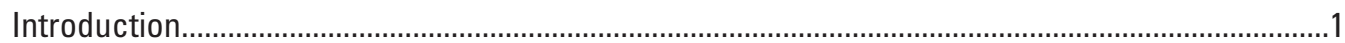

Purpose and Scope ........................................................................................................

Meteorological History of Hurricane Sandy ....................................................................

Analysis of Storm-Tide and Wave Data from Hurricane Sandy .................................................10

Peak Storm-tide Elevations from USGS Tide Gages ...........................................................10

Peak Storm-Tide Elevations and Wave Statistics from USGS Temporary Storm Tide

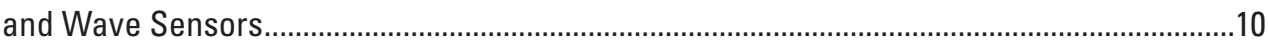

Peak Storm-Tide Elevations from USGS High-Water-Mark Data ...........................................13

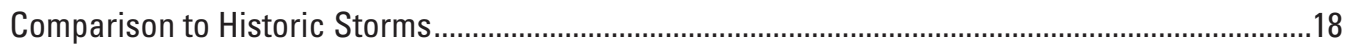

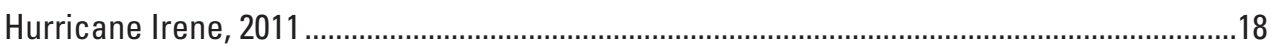

December 1992, The Great Nor'easter...................................................................................18

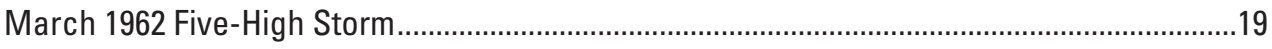

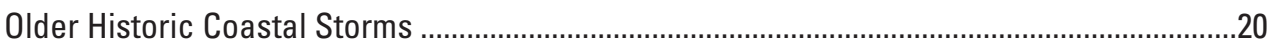

Flood Frequency Comparison and Analysis ..........................................................................24

Estimated Exceedance Probabilities for Peak Storm-Tide Elevations from

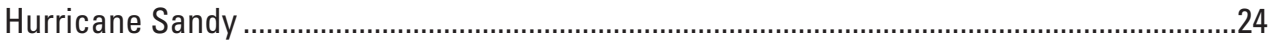

Geographic Information System Data Processing and Methods ........................................25

Comparison of Historic Exceedance Probabilities for Atlantic City......................................25

Storm Surge Analysis...........................................................................................................

Storm-Surge Magnitude and Timing Associated with Hurricane Sandy ................................30

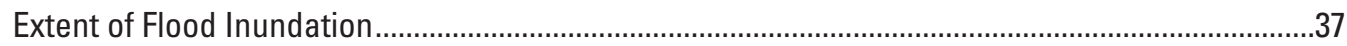

Comparison of Hindcast Model Predictions with Final USGS Verified Inundations.................37

General Description of Flood Damages ....................................................................................

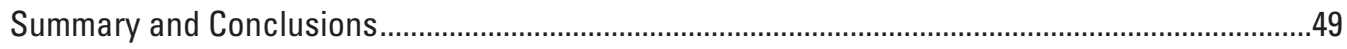

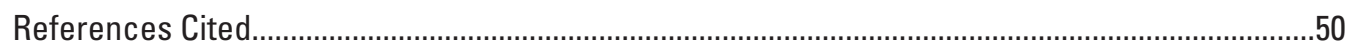

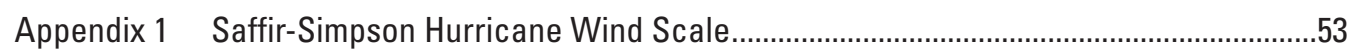

Appendix 2 Storm and Damage Photographs .......................................................................5 


\section{Figures}

1. Map showing storm track for Hurricane Sandy, October 22-29, 2012, and extratropical track from October 29-31, 2012. Figure courtesy of the National Hurricane Center, Sandy Report

2. Map showing satellite image of Hurricane Sandy on October 28, 2012, shortly before making landfall on the coast of New Jersey. Photograph courtesy of NASA Earth Observatory. Outline of east coast annotated by NASA and imbedded with image

3. Map showing total rainfall for the period of October 29-31, 2012, at selected National Weather Service precipitation gages in New Jersey and Delaware

4. Map showing peak storm-tide elevations for real-time tide gages operated as part of the New Jersey Tide Telemetry Network.

5. Photographs showing A, U.S. Geological Survey temporary storm-tide sensors deployed in protective metal housing to measure storm surge from Hurricane Sandy, and $B$, high-water mark on the side of a house along the coast of New Jersey produced by storm tide associated with Hurricane Sandy...

6. Map showing peak storm-tide elevation for U.S. Geological Survey temporary storm-tide sensors deployed along the New Jersey coast.

7. Graph showing water-surface elevation data collected at a 2-second interval and filtered 3-minute average storm-tide elevations at U.S. Geological Survey storm-tide and wave sensor, SSS-NJ-MON-003WV, Sea Bright, NJ, October 29-30, 2012.

8. Graphs showing wave statistics computed from 2-second data collected at U.S. Geological Survey storm-tide and wave sensor, SSS-NJ-MON-003WV, Sea Bright, $\mathrm{NJ}$, October 29-30, 2012, using experimental spectral analysis tool.....

9. Map showing peak storm-tide elevations at selected high-water-mark sites along the coast of New Jersey for the coastal flood of October 29-30, 2012.

10. Satellite image of Hurricane Irene, August 28, 2011, as it was making landfall near New York City. Photograph courtesy of National Oceanic and Atmospheric Administration.

11. Satellite image showing National Weather Service map of total observed precipitation in New Jersey and vicinity for 24-hour period ending August 28, 2011, at 0800 hours eastern daylight time.

12. Graphs showing hourly tide elevations at National Oceanic and Atmospheric Administration tide gages at $A$, Sandy Hook and $B$, Cape May during the December 1992 nor'easter storm, December 9-14, 1992

13. Graph showing hourly tide elevations at National Oceanic and Atmospheric Administration tide station at Sandy Hook, NJ, during the March 1962 "Five High" storm.

14. Map showing location and elevation of high-water marks flagged and surveyed after the December 1992 nor'easter storm and selected nearby high-water marks from Hurricane Sandy, October 29-30, 2012, along the coast of New Jersey.

15. Map showing peak storm-tide elevation recurrence intervals for U.S. Geological Survey tide gages and storm-tide sensor sites along the coast of New Jersey for Hurricane Sandy, October 29-30, 2012

16. Map showing peak storm-tide elevation recurrence intervals for U.S. Geological Survey high-water-mark sites along the coast of New Jersey for Hurricane Sandy, October 29-30, 2012. 
17. Maps showing $A$, estimated areas of inundation during the storms of 1960 and 1962, and Hurricane Sandy, October 29-30, 2012, Absecon Island, NJ, and B, high-water marks from the three storms in Atlantic City, New Jersey.....

18. Graphs showing predicted and recorded storm-tide elevations, and computed storm surge during 0 ctober 27-November 1, 2012, at selected tide gages along the coast of New Jersey: $A$, Raritan Bay, $B$, Shrewsbury River, $C$, Manasquan River, $D$, Barnegat Bay, E, Barnegat Inlet, $F$, Little Egg Inlet, G, Absecon Creek, and H, Cape May Harbor.

19. Maps showing elevation data for Mantoloking, NJ, collected $A$, before, $B$, after the storm tide associated with Hurricane Sandy that damaged the New Jersey coastline on October, 29-30, 2012, and $C$, change in elevation from before to after the storm tide.

20. Maps showing A, Federal Emergency Management Agency estimated area of inundation along the coast of New Jersey from Hurricane Sandy, February 2013, $B$, estimated depth of inundation at U.S. Geological Survey (USGS) high-watermark sites within about 0.5 mile from the coastline, and $C$, cross-section view of peak water-surface elevations at USGS high-water-mark sites within 0.5 mile of the coastline and the National Elevation dataset ground elevations at those locations from Cape May County to Bergen County, New Jersey, October 29-30, 2012

21. Maps showing estimated areas of inundation along the coast of New Jersey using the Federal Emergency Management Agency initial prediction of inundation and final inundation verified by U.S. Geological Survey high-water marks for Hurricane Sandy, October 29-30, 2012, in the $A$, Raritan Bay area, $B$, Mantoloking to Barnegat Light area, and $C$, Atlantic City to Cape May area and Delaware Bay to Delaware River area.

22. Map showing estimated areas of inundation at Tuckerton, New Jersey, and nearby vicinity, using the Federal Emergency Management Agency initial October 31,2012 , prediction of inundation and final February 14, 2013, inundation estimates verified by U.S. Geological Survey high-water marks for Hurricane Sandy, October 29-30, 2012.

23. Maps showing estimated total building stock losses by county in New Jersey from Hurricane Sandy, October 29-30, 2012, using a level 1 HAZUS analysis of initial through final inundation estimates from $A$, October 31, 2012, $B$, November 11,2012 , and $C$, February 14, 2013, and $D$, the difference between February and October estimates

24. Satellite image of Hurricane Sandy $A$, on October 28, 2012, as it approached the coast of New Jersey, and $B$, over eastern United States showing the blackout in New Jersey and the surrounding area after making landfall in New Jersey . .44

25. Photos showing flood damage from Hurricane Sandy in New Jersey: $A$, car trying to drive through flood waters on Route 46 in Little Ferry, NJ, October, 30, 2012, B, residents cleaning up debris and sending a message, $C$, damages in Ocean City and $D$, Birck Township, $E$, flooded streets of Hoboken, November 2, 2012, and $F$, massive debris pile at Seaside Heights Water Tower, November 5, 2012. 


\section{Tables}

1. Maximum recorded wind speed, wind gusts, and minimum barometric pressure during Hurricane Sandy, October 29-30, 2012, at selected National Oceanic and Atmospheric Administration and partnership stations in New Jersey and selected surrounding areas.

2. Total rainfall from Hurricane Sandy recorded at selected NWS precipitation gages in New Jersey and Delaware, October 29-31, 2012

3. Peak-of-record tide elevations and peak storm-tide elevations at U.S. Geological Survey permanent monitoring tide gages in New Jersey, October 29-30, 2012. (Table 3 available online at http://dx.doi.org/10.3133/sir20165085)

4. Description of U.S. Geological Survey sensors temporarily deployed for Hurricane Sandy with peak storm-tide elevations, annual exceedance probabilities, and estimated recurrence intervals in New Jersey, October 29-30, 2012. (Table 4 available online at http://dx.doi.org/10.3133/sir20165085)

5. Peak storm-tide elevations at 169 high-water-mark sites along the coast of New Jersey during Hurricane Sandy, October 29-30, 2012, and the corresponding Federal Emergency Management Agency flood elevations for the 10-, 50-, 100-, and 500-year recurrence intervals. (Table 5 available online at http://dx.doi.org/10.3133/ sir20165085)

6. Peak storm-tide elevations for selected historic coastal floods and peak stormtide elevations during Hurricane Sandy, October 29-30, 2012, at selected U.S. Geological Survey permanent monitoring tide gages in New Jersey. (Table 6 available online at http://dx.doi.org/10.3133/sir20165085)

7 Peak storm-tide elevations at 82 high-water-mark sites flagged and surveyed after the December 1992 storm in New Jersey, peak storm-tide elevations from the closest high-water-mark sites flagged and surveyed after Hurricane Sandy, October 29-30, 2012, and peak storm-tide elevations from the nearest U.S. Geological Survey tide gage along the coast of New Jersey during Hurricane Sandy, October 29-30, 2012. (Table 7 available online at http://dx.doi.org/10.3133/ sir20165085) 


\section{Conversion Factors}

\begin{tabular}{|c|c|c|}
\hline Multiply & By & To obtain \\
\hline \multicolumn{3}{|c|}{ Length } \\
\hline inch (in.) & 2.54 & centimeter $(\mathrm{cm})$ \\
\hline inch (in.) & 25.4 & millimeter $(\mathrm{mm})$ \\
\hline foot $(\mathrm{ft})$ & 0.3048 & meter $(\mathrm{m})$ \\
\hline mile (mi) & 1.609 & kilometer (km) \\
\hline mile, nautical (nmi) & 1.852 & kilometer (km) \\
\hline \multicolumn{3}{|c|}{ Area } \\
\hline square foot $\left(\mathrm{ft}^{2}\right)$ & 929.0 & square centimeter $\left(\mathrm{cm}^{2}\right)$ \\
\hline square foot $\left(\mathrm{ft}^{2}\right)$ & 0.09290 & square meter $\left(\mathrm{m}^{2}\right)$ \\
\hline square mile $\left(\mathrm{mi}^{2}\right)$ & 259.0 & hectare (ha) \\
\hline square mile $\left(\mathrm{mi}^{2}\right)$ & 2.590 & square kilometer $\left(\mathrm{km}^{2}\right)$ \\
\hline \multicolumn{3}{|c|}{ Volume } \\
\hline gallon (gal) & 0.003785 & cubic meter $\left(\mathrm{m}^{3}\right)$ \\
\hline gallon (gal) & 3.785 & cubic decimeter $\left(\mathrm{dm}^{3}\right)$ \\
\hline million gallons (Mgal) & 3,785 & cubic meter $\left(\mathrm{m}^{3}\right)$ \\
\hline cubic foot $\left(\mathrm{ft}^{3}\right)$ & 28.32 & cubic decimeter $\left(\mathrm{dm}^{3}\right)$ \\
\hline cubic foot $\left(\mathrm{ft}^{3}\right)$ & 0.02832 & cubic meter $\left(\mathrm{m}^{3}\right)$ \\
\hline \multicolumn{3}{|c|}{ Flow rate } \\
\hline cubic foot per second $\left(\mathrm{ft}^{3} / \mathrm{s}\right)$ & 0.02832 & cubic meter per second $\left(\mathrm{m}^{3} / \mathrm{s}\right)$ \\
\hline $\begin{array}{l}\text { cubic foot per second per square mile } \\
{\left[\left(\mathrm{ft}^{3} / \mathrm{s}\right) / \mathrm{mi}^{2}\right]}\end{array}$ & 0.01093 & $\begin{array}{l}\text { cubic meter per second per square } \\
\text { kilometer }\left[\left(\mathrm{m}^{3} / \mathrm{s}\right) / \mathrm{km}^{2}\right]\end{array}$ \\
\hline million gallons per day (Mgal/d) & 0.04381 & cubic meter per second $\left(\mathrm{m}^{3} / \mathrm{s}\right)$ \\
\hline
\end{tabular}

Vertical elevation information is referenced to the North American Vertical Datum of 1988 (NAVD 88) or the National Geodetic Vertical Datum of 1929 (NGVD 1929)

Horizontal coordinate information is referenced to the North American Datum of 1983 (NAD 83).

Elevation, as used in this report, refers to distance above the vertical datum. 



\title{
Documentation and Hydrologic Analysis of Hurricane Sandy in New Jersey, October 29-30, 2012
}

\author{
By Thomas P. Suro, Anna Deetz, and Paul Hearn
}

\section{Abstract}

In 2012, a late season tropical depression developed into a tropical storm and later a hurricane. The hurricane, named "Hurricane Sandy," gained strength to a Category 3 storm on October 25, 2012, and underwent several transitions on its approach to the mid-Atlantic region of the eastern coast of the United States. By October 28, 2012, Hurricane Sandy had strengthened into the largest hurricane ever recorded in the North Atlantic and was tracking parallel to the east coast of United States, heading toward New Jersey. On October 29, 2012, the storm turned west-northwest and made landfall near Atlantic City, N.J. The high winds and wind-driven storm surge caused massive damage along the entire coastline of New Jersey. Millions of people were left without power or communication networks. Many homes were completely destroyed. Sand dunes were eroded, and the barrier island at Mantoloking was breached, connecting the ocean with Barnegat Bay.

Several days before the storm made landfall in New Jersey, the U.S. Geological Survey (USGS) made a decision to deploy a temporary network of storm-tide sensors and barometric pressure sensors from Virginia to Maine to supplement the existing USGS and National Oceanic and Atmospheric Administration (NOAA) networks of permanent tide monitoring stations. After the storm made landfall, the USGS conducted a sensor data recovery and high-water-mark collection campaign in cooperation with the Federal Emergency Management Agency (FEMA).

Peak storm-tide elevations documented at USGS tide gages, tidal crest-stage gages, temporary storm sensor locations, and high-water-mark sites indicate the area from southern Monmouth County, N.J., north through Raritan Bay, N.J., had the highest peak storm-tide elevations during this storm. The USGS tide gages at Raritan River at South Amboy and Raritan Bay at Keansburg, part of the New Jersey Tide Telemetry System, each recorded peak storm-tide elevations of greater than 13 feet $(\mathrm{ft})$ - more than $5 \mathrm{ft}$ higher than the previously recorded period-of-record maximum. A comparison of peak storm-tide elevations to preliminary FEMA Coastal Flood Insurance Study flood elevations indicated that these areas experienced the highest recurrence intervals along the coast of New Jersey. Analysis showed peak storm-tide elevations exceeded the 100-year FEMA flood elevations in many parts of Middlesex, Union, Essex, Hudson, and Bergen Counties, and peak storm-tide elevations at many locations in Monmouth County exceeded the 500-year recurrence interval. A level 1 HAZUS (HAZards United States) analysis was done for the counties in New Jersey affected by flooding to estimate total building stock losses. The aggregated total building stock losses estimated by HAZUS for New Jersey, on the basis of the final inundation verified by USGS high-water marks, was almost $\$ 19$ billion. A comparison of Hurricane Sandy with historic coastal storms showed that peak stormtide elevations associated with Hurricane Sandy exceeded most of the previously documented elevations associated with the storms of December 1992, March 1962, September 1960, and September 1944 at many coastal communities in New Jersey. This scientific investigation report was prepared in cooperation with FEMA to document flood processes and flood damages resulting from this storm and to assist in future flood mitigation actions in New Jersey.

\section{Introduction}

In late October 2012, Tropical Storm Sandy was upgraded to Category 1 hurricane status on the Saffir-Simpson Hurricane Wind Scale (National Hurricane Center, 2013a; appendix 1) as it tracked toward the southeastern United States coast. On October 28, Hurricane Sandy had grown into the largest hurricane ever recorded in the North Atlantic and was tracking parallel to the east coast of United States and heading toward New Jersey. Hurricane Sandy was the second largest hurricane on record behind Hurricane Katrina that devastated the Gulf coast in 2005. On Monday, October 29, Hurricane Sandy made landfall along the New Jersey coast near Atlantic City as it was being downgraded from a Category 1 hurricane to a tropical storm (hereafter referred to as "Hurricane Sandy"). Hurricane Sandy caused major coastal flooding and structural damage to the entire coastline of New Jersey and part of New York (fig.1).

Prior to the storm making landfall in the mid-Atlantic region, the U.S. Geological Survey (USGS), in cooperation 


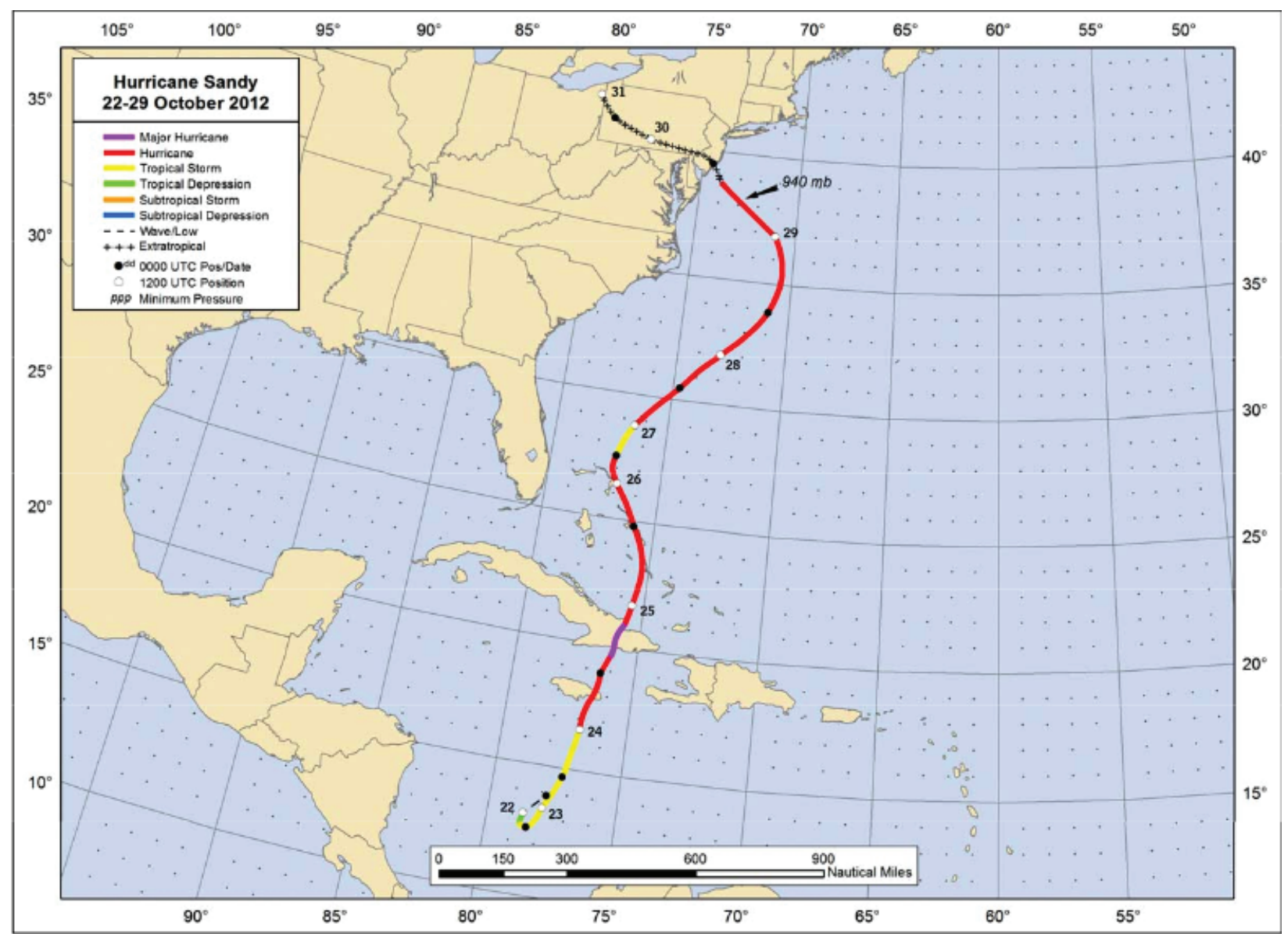

Figure 1. Storm track for Hurricane Sandy, October 22-29, 2012, and extratropical track from October 29-31, 2012. Figure courtesy of the National Hurricane Center, Sandy Report. (National Hurricane Center, 2013b)

with the Federal Emergency Management Agency (FEMA), deployed a temporary network of 224 storm-tide and barometric-pressure sensors along the northern half of the east coast from Virginia to Maine to continuously record water levels and barometric pressures throughout the storm. This data, which were collected in cooperation with FEMA, augmented data from the network of permanent USGS tide gages and provided additional data to document the timing, depth, and areal extent of flooding associated with this storm (McCallum and others, 2013).

Due to its large size and offshore path into the midAtlantic region, Hurricane Sandy produced record setting storm-tide elevations along the New Jersey coast, primarily due to its large wind field. The USGS operates weather sensors at selected tide gages along the New Jersey coast to record unofficial temporary wind speed and directional data for general reference. The sensors are calibrated once annually, but routine maintenance and quality assurance measures are not performed on a regular basis. Therefore, the data are generally not considered reliable for scientific or interpretative research or studies but are generally used to facilitate field work and for general reference. As a general reference, the USGS wind sensors recorded wind speeds of 40-50 miles per hour (mph) at Cape May, N.J., and 50-60 mph at Barnegat Light, N.J., (with gusts of almost $80 \mathrm{mph}$ ) during the storm on October 29,2012 . These data agree closely with data recorded by the National Oceanic and Atmospheric Administration (NOAA). The maximum sustained wind speed, which was recorded by NOAA at their Center for Operational Oceanographic Products and Services (CO-OPS) and partnership stations from North Carolina to New England during the passage of Hurricane Sandy, was $59.7 \mathrm{mph}$ at Cape May, N.J., on October 29, 2012, (National Oceanic and Atmospheric Administration, 2013) near the time when Hurricane Sandy made landfall. The maximum wind gust recorded by NOAA during the time when the storm made landfall in New Jersey was $75.1 \mathrm{mph}$, which was recorded at Cape May, N.J. Sustained wind speed and wind gusts were computed by NOAA using averaging times of 1 minute and 3-5 seconds, respectively (National Oceanic and Atmospheric Administration, 2015a). The minimum barometric pressure recorded by NOAA near the time of landfall was recorded as 945.5 millibars (mbar) at Atlantic City, N.J., on October 29, 2012, at 22:24 Greenwich Mean Time (GMT). Wind data recorded during Hurricane Sandy at selected NOAA stations in New Jersey and the surrounding areas are listed in table 1. 


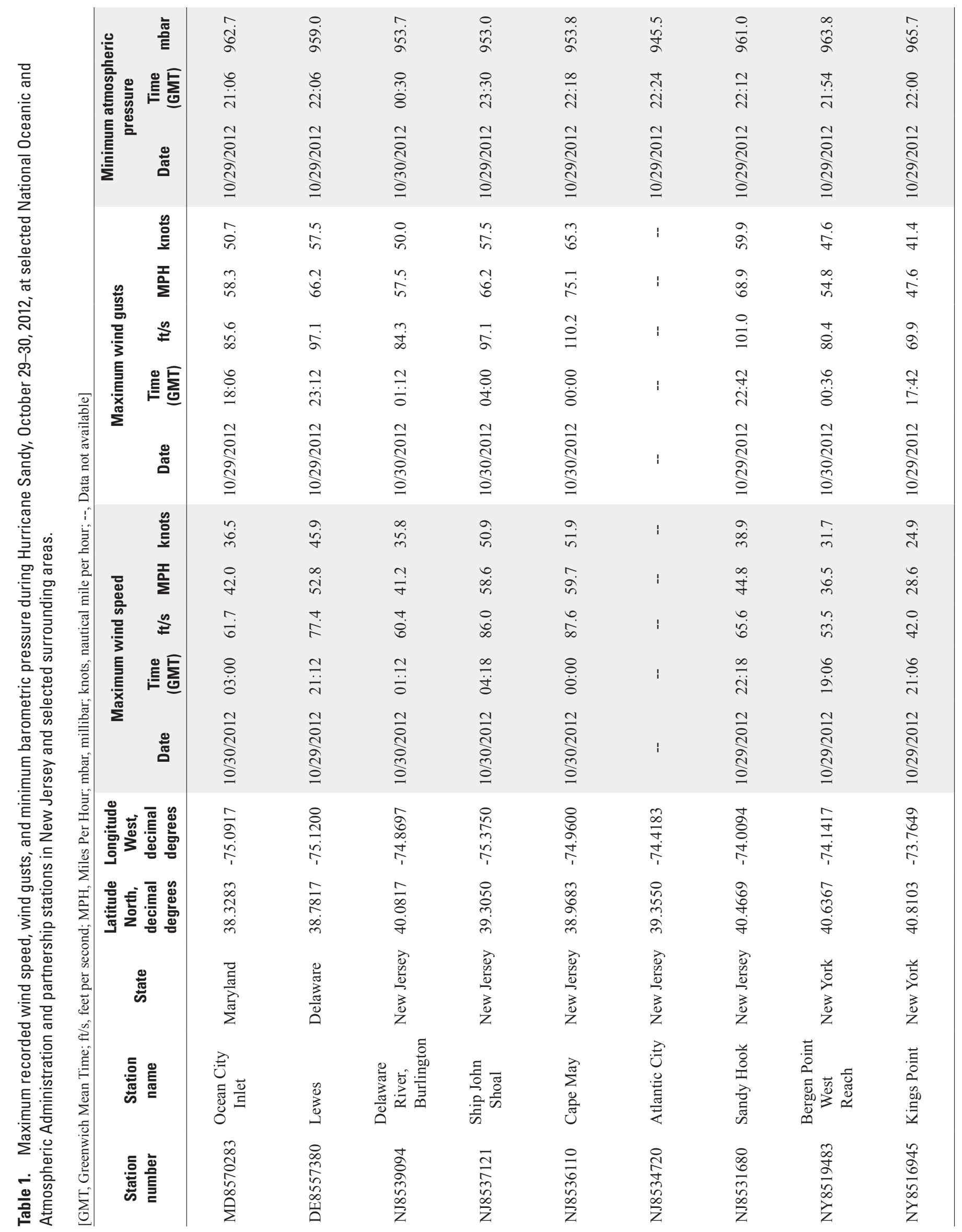


Heavy rain associated with Hurricane Sandy was reported throughout parts of southern and central New Jersey, but the heavy rain did not cause major inland riverine flooding to the extent that some previous extratropical storms had done in recent years. The National Weather Service (NWS) recorded rainfall totals of more than 8 inches at Cape May Harbor and Atlantic City, N.J., and more than 6 inches at Barnegat Light and Seabrook, N.J. At many locations along the coast, rainfall totals of more than 3 inches were recorded. Farther inland, rainfall was even less with storm totals of less than 3 inches at Mount Holly, North Princeton, and Clinton, N.J. This storm was different from a typical hurricane or nor'easter because it had the characteristics of both. A nor'easter is a storm along the east coast of North America, so called because the winds over the coastal area are typically from the northeast (National Oceanic and Atmospheric Administration, 2015b). Hurricane Sandy approached the eastern United States as a hurricane, but as it moved north, it interacted with a low pressure trough and transitioned into a very large hybrid storm with a tropical system wind and rain field that was almost 1,000 miles across.

The high winds and heavy rain caused peak storm-tide elevations along the entire coast of New Jersey that exceeded the previous records set during the December 1992, March 1962, and September 1944 storms at most locations. The USGS recorded new period-of-record peak storm-tide elevations at 22 tide gages and 25 tidal crest-stage gages along the coast of New Jersey as a result of this storm. Peak stormtide elevation data collected by the USGS indicate stillwater elevations during Hurricane Sandy equaled or exceeded the 1-percent annual chance elevation (100-year flood elevation), and in some cases the 0.2-percent annual chance elevation (500-year flood elevation), determined in the new preliminary FEMA flood insurance studies (FIS) at several locations along the New Jersey coast. For this report, stillwater elevations are elevations that are considered to be absent or minimally affected by wind-driven waves. This storm was responsible for major damages to roads, bridges, and infrastructure. Initial media reports stated that an estimated dozen people or more died and more than 7 million people were without power (FoxNews, 2012). Additional reports indicated that Hurricane Sandy knocked out about 25 percent of the cell towers across 10 states before making landfall in New Jersey. Damages in New Jersey after the storm made landfall were estimated to be in the billions.

\section{Purpose and Scope}

This report documents the effects of coastal flooding from Hurricane Sandy in New Jersey prepared in cooperation with FEMA. Peak storm-tide elevations, comparisons to selected historic coastal storms, estimated recurrence intervals for peak storm-tide elevations using FEMA preliminary flood insurance study data, magnitude and timing of storm surge, and comparisons of selected inundation maps derived from differing amounts of model and USGS sensor and high-water-mark data are presented. These data and analysis are presented to document flood processes and flood damages resulting from this storm and to assist in future flood mitigation actions in New Jersey.

\section{Meteorological History of Hurricane Sandy}

Hurricane Sandy formed as a tropical depression on October 18, 2012, and grew into a tropical storm on October 22. It was the 18th named storm of the Atlantic hurricane season. The Atlantic hurricane season produced 19 named storms, 10 of which became hurricanes. The storm continued to grow and reached Category 1 hurricane status on the Saffir-Simpson Hurricane Wind Scale as it made landfall in Jamaica. It intensified to a Category 3 hurricane as it approached eastern Cuba on October 25 before quickly weakening to a Category 1 hurricane. After reaching the northern edge of Cuba, it weakened to tropical storm intensity but was almost double in size relative to the average radius of tropical-storm force winds (National Hurricane Center, 2013b). Although Hurricane Sandy started out as a classic late-season hurricane, it underwent complex changes and grew considerably in size as it moved north of Cuba and through the Bahamas. As Hurricane Sandy passed the Bahamas, it regained hurricane strength, partly fueled by a low pressure trough over the United States, and increased its forward speed as it gradually turned northeast to parallel the southeastern coast of the United States. It was not the re-intensification to hurricane strength that made this an unusual storm; it was the complex structure and overall size of the tropical-storm force wind fields. Early on October 29, the hurricane encountered a blocking high pressure pattern in the North Atlantic, which prevented it from turning out to sea. As the high pressure continued to build, the low pressure trough in the central United States deepened. Part of the low pressure trough moved eastward causing decreased vertical wind shear for Hurricane Sandy and helped to steer the storm northwest toward the East Coast of the United States. The low pressure trough combined with warm gulfstream waters helped to re-intensify the storm early on the October 29. As the storm continued to move northwest toward New Jersey, the cooler air and waters helped weaken the hurricane to tropical storm status before it made landfall near Atlantic City, N.J., as a massive extra tropical storm system (fig 2). Although Hurricane Sandy never intensified to a Category 5 hurricane, and weakened to a tropical storm before making landfall in New Jersey, it was the largest hurricane ever recorded in the North Atlantic. It produced gale- to storm-force winds along the coast of New Jersey and New York for 12-18 hours, causing record coastal flooding and damage. The media labeled the storm "Superstorm Sandy" (CBS News, 2012) due to (1) its extremely large size, (2) its tropical-storm force wind field that was almost 1,000 miles wide, and (3) its complex hybrid storm characteristics. The NWS reported that Tropical Storm Sandy made landfall near 


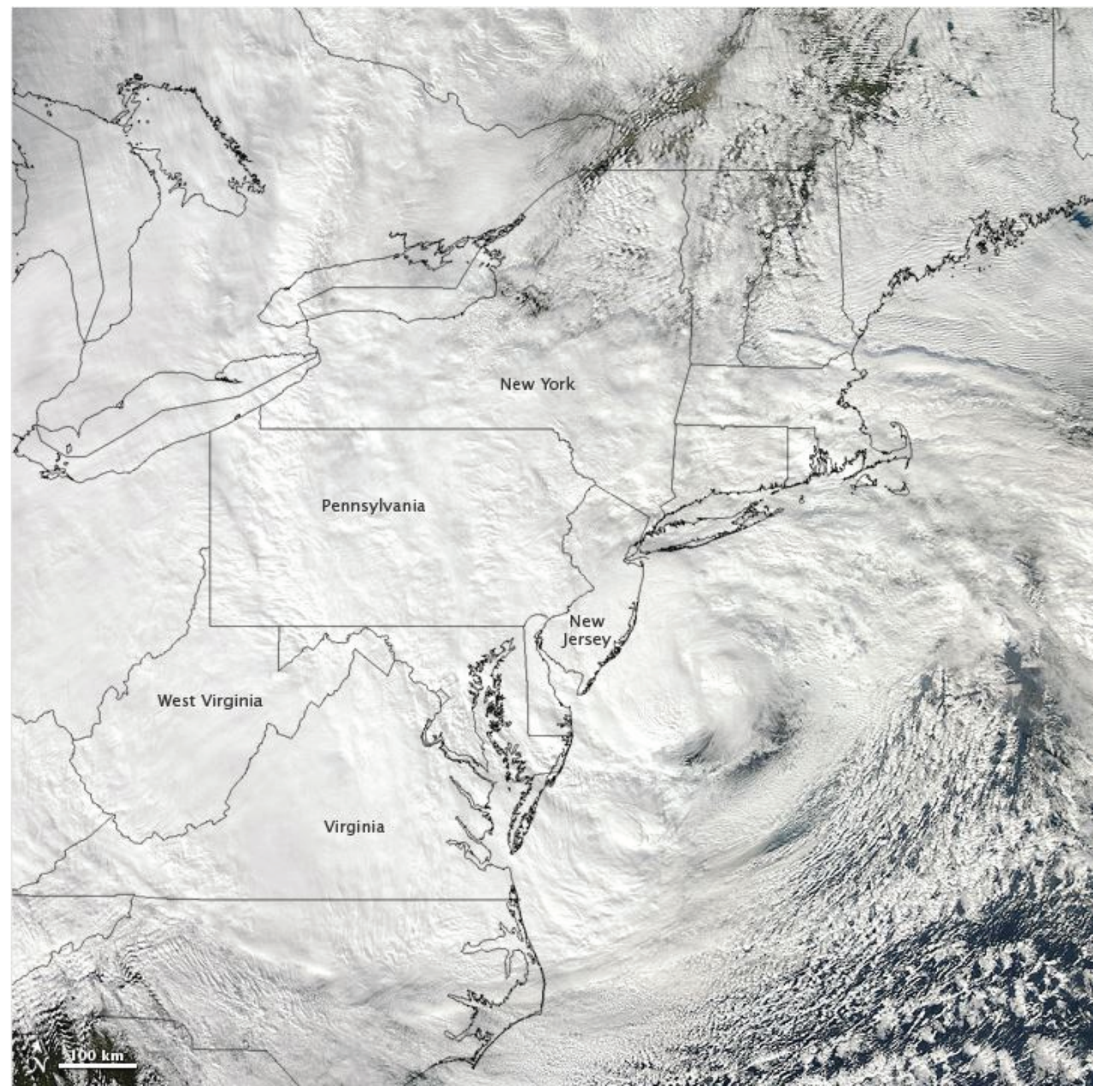

Figure 2. Satellite image of Hurricane Sandy on October 28, 2012, shortly before making landfall on the coast of New Jersey. Photograph courtesy of NASA Earth Observatory. Outline of east coast annotated by NASA and imbedded with image.

Atlantic City, N.J., with an estimated intensity of 70 knots (80.6 mph) and a minimum pressure of 945 mbar (NOAA, 2012). The USGS recorded unofficial sustained winds of 50-60 mph and gusts of almost $80 \mathrm{mph}$ near Barnegat Light, N.J., on October 29. Rainfall totals were generally in the range of 4-6 inches in the area surrounding Atlantic City, with larger rainfall totals to the south and smaller totals to the north (fig 3). The NWS recorded rainfall totals of greater than
8 inches at its recording stations in Atlantic City, N.J., and Cape May, N.J., whereas Cowanesque Dam gages recorded a rainfall total of just over 10 inches (table 2; fig. 3). Although rainfall totals generally ranged from 2 to 5 inches across New Jersey, widespread river flooding was not documented. However, major coastal flooding and new record storm tides were recorded at most locations along the coast of New Jersey, New York City, and Long Island. 


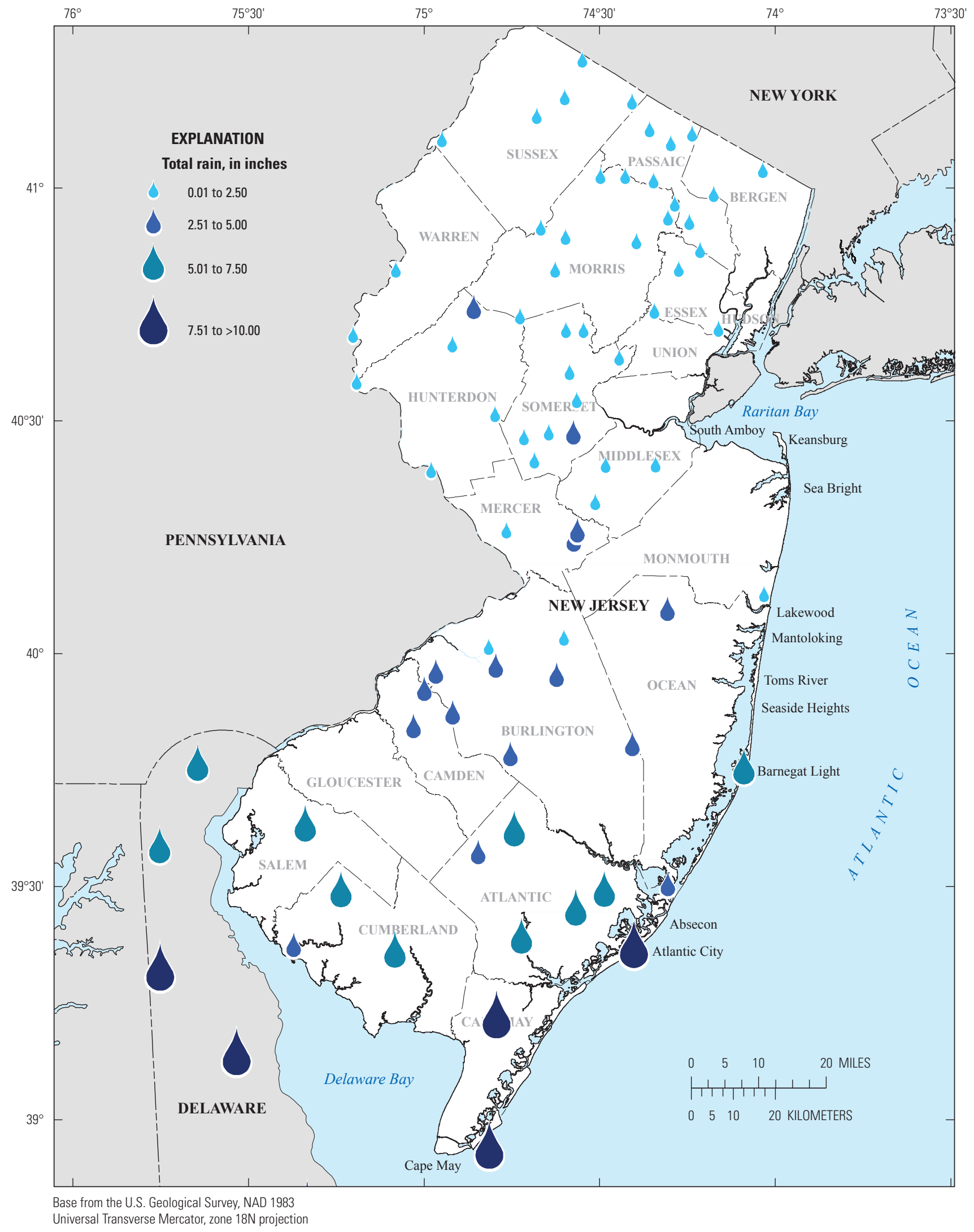

Figure 3. Total rainfall for the period of October 29-31, 2012, at selected National Weather Service precipitation gages in New Jersey and Delaware. 
Table 2. Total rainfall from Hurricane Sandy recorded at selected NWS precipitation gages in New Jersey and Delaware, October 29-31, 2012.

[NWS, National Weather Service]

\begin{tabular}{|c|c|c|c|c|c|}
\hline $\begin{array}{c}\text { NWS } \\
\text { site identification }\end{array}$ & $\begin{array}{l}\text { NWS } \\
\text { site name }\end{array}$ & State & $\begin{array}{c}\text { Latitude North } \\
\text { (decimal degrees) }\end{array}$ & $\begin{array}{l}\text { Longitude West } \\
\text { (decimal degrees) }\end{array}$ & $\begin{array}{c}\text { Total rainfall } \\
\text { (inches) }\end{array}$ \\
\hline CPMN4 & Cowanesque Dam & New Jersey & 38.950 & -74.933 & 10.01 \\
\hline ATLN4 & Atlantic City & New Jersey & 39.380 & -74.420 & 8.40 \\
\hline CAPN4 & Cape May Harbor & New Jersey & 38.950 & -74.820 & 8.17 \\
\hline WOBN4 & Woodbine & New Jersey & 39.230 & -74.800 & 7.97 \\
\hline ESMN4 & Estelle Manor & New Jersey & 39.400 & -74.730 & 7.08 \\
\hline SEAN4 & Seabrook & New Jersey & 39.500 & -75.230 & 6.56 \\
\hline $\mathrm{ACY}$ & Atlantic City Airpot & New Jersey & 39.460 & -74.580 & 6.00 \\
\hline MIV & Millville Airport & New Jersey & 39.370 & -75.080 & 5.88 \\
\hline HMTN4 & Hammonton & New Jersey & 39.630 & -74.750 & 5.51 \\
\hline OCVN4 & Oceanville & New Jersey & 39.500 & -74.500 & 5.21 \\
\hline JCRN4 & New Castle 4W & New Jersey & 39.509 & -74.324 & 4.91 \\
\hline CTWN4 & Chatsworth & New Jersey & 39.810 & -74.420 & 4.79 \\
\hline NLBN4 & New Lisbon & New Jersey & 39.960 & -74.630 & 3.48 \\
\hline BKWN4 & Blackwells Mill & New Jersey & 40.480 & -74.580 & 3.36 \\
\hline PENN4 & Pennsauken & New Jersey & 39.930 & -75.000 & 2.97 \\
\hline JACN4 & Jackson & New Jersey & 40.100 & -74.320 & 2.94 \\
\hline MLTN4 & Marlton & New Jersey & 39.880 & -74.920 & 2.93 \\
\hline MORN4 & Moorefield & New Jersey & 39.967 & -74.967 & 2.92 \\
\hline GRWN4 & Greenwich & New Jersey & 39.380 & -75.360 & 2.75 \\
\hline MTHN4 & Mt. Holly & New Jersey & 39.980 & -74.800 & 2.73 \\
\hline WNDN4 & Windsor & New Jersey & 40.250 & -74.580 & 2.71 \\
\hline CALN4 & Califon & New Jersey & 40.750 & -74.860 & 2.65 \\
\hline
\end{tabular}


Table 2. Total rainfall from Hurricane Sandy recorded at selected NWS precipitation gages in New Jersey and Delaware, October 29-31, 2012.-Continued

[NWS, National Weather Service]

\begin{tabular}{|c|c|c|c|c|c|}
\hline $\begin{array}{c}\text { NWS } \\
\text { site identification }\end{array}$ & $\begin{array}{c}\text { NWS } \\
\text { site name }\end{array}$ & State & $\begin{array}{c}\text { Latitude North } \\
\text { (decimal degrees) }\end{array}$ & $\begin{array}{l}\text { Longitude West } \\
\text { (decimal degrees) }\end{array}$ & $\begin{array}{l}\text { Total rainfall } \\
\text { (inches) }\end{array}$ \\
\hline HGTN4 & Hightstown & New Jersey & 40.270 & -74.570 & 2.57 \\
\hline PHIN4 & Mt. Holly NWS & New Jersey & 40.020 & -74.820 & 2.44 \\
\hline RGLN4 & Riegelsville & New Jersey & 40.590 & -75.190 & 2.41 \\
\hline HLLN4 & Wawayanda State Park & New Jersey & 41.190 & -74.410 & 2.36 \\
\hline WRIN4 & Wrightstown & New Jersey & 40.040 & -74.610 & 2.34 \\
\hline STKN4 & Stockton & New Jersey & 40.400 & -74.980 & 2.31 \\
\hline NESN4 & Neshanic & New Jersey & 40.470 & -74.720 & 2.16 \\
\hline FHLN4 & Far Hills & New Jersey & 40.700 & -74.600 & 2.15 \\
\hline CHAN4I & Charlotteburg & New Jersey & 41.030 & -74.430 & 2.12 \\
\hline DEAN4 & Deans 2E & New Jersey & 40.410 & -74.490 & 2.11 \\
\hline MRTN4 & Martinsville & New Jersey & 40.610 & -74.590 & 2.08 \\
\hline CLIN4 & Clinton & New Jersey & 40.670 & -74.920 & 2.00 \\
\hline WALN4 & Wallkill 1NW & New Jersey & 41.280 & -74.550 & 1.85 \\
\hline FLMN4 & Flemington & New Jersey & 40.520 & -74.800 & 1.83 \\
\hline WTMN4 & West Milford & New Jersey & 41.130 & -74.360 & 1.80 \\
\hline WWNN4 & West Wharton & New Jersey & 40.900 & -74.600 & 1.80 \\
\hline ORRN4 & Oak Ridge Reservoir & New Jersey & 41.030 & -74.500 & 1.76 \\
\hline ODBN4 & Old Bridge & New Jersey & 40.410 & -74.350 & 1.71 \\
\hline WTCN4 & Watchung & New Jersey & 40.640 & -74.450 & 1.70 \\
\hline BBKN4 & Bound Brook & New Jersey & 40.550 & -74.570 & 1.60 \\
\hline BKRN4 & Basking Ridge & New Jersey & 40.700 & -74.550 & 1.60 \\
\hline
\end{tabular}


Table 2. Total rainfall from Hurricane Sandy recorded at selected NWS precipitation gages in New Jersey and Delaware, October 29-31, 2012.-Continued

[NWS, National Weather Service]

\begin{tabular}{|c|c|c|c|c|c|}
\hline $\begin{array}{c}\text { NWS } \\
\text { site identification }\end{array}$ & $\begin{array}{c}\text { NWS } \\
\text { site name }\end{array}$ & State & $\begin{array}{c}\text { Latitude North } \\
\text { (decimal degrees) }\end{array}$ & $\begin{array}{l}\text { Longitude West } \\
\text { (decimal degrees) }\end{array}$ & $\begin{array}{c}\text { Total rainfall } \\
\text { (inches) }\end{array}$ \\
\hline IRON4 & Ironia & New Jersey & 40.830 & -74.630 & 1.60 \\
\hline RINN4 & Ringwood & New Jersey & 41.120 & -74.240 & 1.56 \\
\hline LAKN4G & Lake Hopatcong & New Jersey & 40.920 & -74.670 & 1.55 \\
\hline PELN4 & Pellettown & New Jersey & 41.160 & -74.680 & 1.54 \\
\hline FLAN4 & Flatbrookville & New Jersey & 41.110 & -74.950 & 1.48 \\
\hline MSQN4 & Manasquan & New Jersey & 40.130 & -74.050 & 1.48 \\
\hline PTTN4 & Pottersville & New Jersey & 40.730 & -74.730 & 1.44 \\
\hline STRN4 & Bloomingdale & New Jersey & 41.020 & -74.350 & 1.40 \\
\hline EWR & Newark Airport & New Jersey & 40.700 & -74.170 & 1.39 \\
\hline MONN4 & Monksville & New Jersey & 41.100 & -74.300 & 1.36 \\
\hline PEKN4 & Little Falls & New Jersey & 40.870 & -74.220 & 1.33 \\
\hline BOON4L & Boonton & New Jersey & 40.890 & -74.400 & 1.30 \\
\hline FLKN4 & Franklin Lake & New Jersey & 40.990 & -74.180 & 1.12 \\
\hline ESXN4 & Essex Fells & New Jersey & 40.830 & -74.280 & 1.08 \\
\hline PKRN4 & Park Ridge & New Jersey & 41.040 & -74.040 & 0.95 \\
\hline BERD1 & Benton $3 \mathrm{NE}$ & Delaware & 39.592 & -75.733 & 6.88 \\
\hline BLKD1 & Blackbird & Delaware & 39.33 & -75.73 & 8.35 \\
\hline DOVD1 & Dover Afb & Delaware & 39.15 & -75.517 & 8.89 \\
\hline PRID1 & $\begin{array}{l}\text { Prime Hook Wildlife } \\
\text { Refuge }\end{array}$ & Delaware & 38.82 & -75.32 & 8.49 \\
\hline WILD1 & Williamsburg & Delaware & 39.77 & -75.63 & 6.11 \\
\hline
\end{tabular}




\section{Analysis of Storm-Tide and Wave Data from Hurricane Sandy}

The USGS deployed temporary storm-tide sensors at more than 200 locations along the Atlantic coast from Virginia to Maine a few days before Hurricane Sandy made landfall near Atlantic City, N.J., to augment the existing tide-gage networks and to better document the effects of the storm. Data from the New Jersey tide-gage network, the temporary stormtide sensors deployed in New Jersey, and high water marks in New Jersey are presented in this section.

\section{Peak Storm-tide Elevations from USGS Tide Gages}

The USGS recorded storm-tide data at 23 real-time tide gages and 31 tidal crest-stage gages along the coast of New Jersey. All 23 tide gages recorded new period-of-record peak storm-tide elevations as a result of Hurricane Sandy, and 27 of the 31 tidal crest-stage gages recorded new period-of-record peak storm-tide elevations (table 3, available online at http:// dx.doi.org/10.3133/sir20165085). The USGS New Jersey tide-gage network was established in cooperation with the New Jersey Department of Transportation and is currently maintained in cooperation with the New Jersey Department of Homeland Security. Most of the gages were installed in the bays along the New Jersey coast, utilizing existing support structures, to provide information to emergency managers for evacuation of the barrier islands before access roads become inundated. The gages were not installed with the purpose of providing continuous real-time data during a major hurricane; however, most gages survived without major damage, despite exceeding their designed maximum recordable limits. The maximum tide elevations recorded at every USGS tide gage along the coast of New Jersey were verified, and tidal hydrographs were estimated or reconstructed where needed. The maximum tide elevations were verified using a high water mark (HWM), and tidal hydrographs were estimated to maintain a hydrologic relation with a nearby reference gage. Because the tide gages are subject to wave action, all of the permanent tide gages in the New Jersey real-time monitoring network have been fitted with wave dampening orifices and incorporate a 3-minute averaging algorithm. These methods are consistent with the methods used by NOAA at their tide gages and are designed to facilitate the measurement of the stillwater tide elevation and dampened wind waves.

During Hurricane Sandy, the highest peak storm-tide elevations in New Jersey were recorded along the northern shores of New Jersey and into Raritan Bay (figs. 3-4). The USGS tide gages at Raritan River at South Amboy and Raritan Bay at Keansburg each recorded peak storm-tide elevations of greater than 13 feet (ft), which is more than $5 \mathrm{ft}$ higher than the previously recorded period-of-record maximum. Slightly south, along the Shrewsbury River, the USGS tide gage at Sea
Bright recorded a new period-of-record peak storm-tide elevation of $9.56 \mathrm{ft}$, which is more than $3 \mathrm{ft}$ higher than the previously recorded maximum for this station. Peak tide elevations farther south in Barnegat Bay and Little Egg Harbor showed a similar pattern of new peak storm-tide elevations recorded as a result of Hurricane Sandy. The USGS tide gages in Barnegat Bay at Mantoloking, Seaside Heights, and Waretown each recorded new record peak storm-tide elevations that were about $3 \mathrm{ft}$ higher than the previously recorded maximum. The USGS tide gages around Absecon and Atlantic City south to Cape May recorded new peak storm-tide elevations of about $2.5 \mathrm{ft}-0.5 \mathrm{ft}$ greater than the previously recorded maximums (fig 4). A comparison of the new peak storm-tide elevations with previous maximums is slightly misleading because the period-of-record for some tide gages may be inconsistent and fragmented over the years. In addition, the comparisons of peak storm-tide elevations at USGS tide gages alone does not present a complete picture of the storm tide and storm surge that occurred along the coast of New Jersey and New York. Some of the USGS tide gages are in bays along the coast, and others are adjacent to inlets or on the outer coast. However, many communities along the coast do not have a tide gage nearby for a reference, and even if all of the communities had a tide gage for a reference, the tide elevation alone would not always directly relate to extent of overland inundation. Natural geographic features, dunes, flood walls, and building structures all play a role in determining the extent of wind driven wave propagation and flooding. The USGS in cooperation with FEMA, New Jersey Department of Environmental Protection (NJDEP), and the National Hurricane Center (NHC) deployed special storm-tide sensors prior to landfall and collected HWM data after the storm. The storm-tide sensors recorded data to document the timing, duration, and elevation of the storm tide associated with this major storm near communities that did not have a continuously recording USGS tide gage. The post-storm HWM data were used to verify the depth and extent of the coastal flooding associated with the storm. A temporary storm-tide sensor deployed in a protective metal housing and a HWM (a mud and sand line) on the side of a house along the coast of New Jersey that was inundated by the storm tide from Hurricane Sandy are shown in figure $5 A-B$. A more direct comparison of Hurricane Sandy peaks to previous historic coastal storms is presented in the "Comparison to Historic Storms" section of this report.

\section{Peak Storm-Tide Elevations and Wave Statistics from USGS Temporary Storm Tide and Wave Sensors}

The temporary sensors that were deployed prior to storm landfall were programmed to record the water-surface elevation at their location at 30-second and 2-second intervals. These data were used to document the timing and elevation of the wind and the low atmospheric-pressure-driven storm tide associated with Hurricane Sandy. The raw 30 -second and 


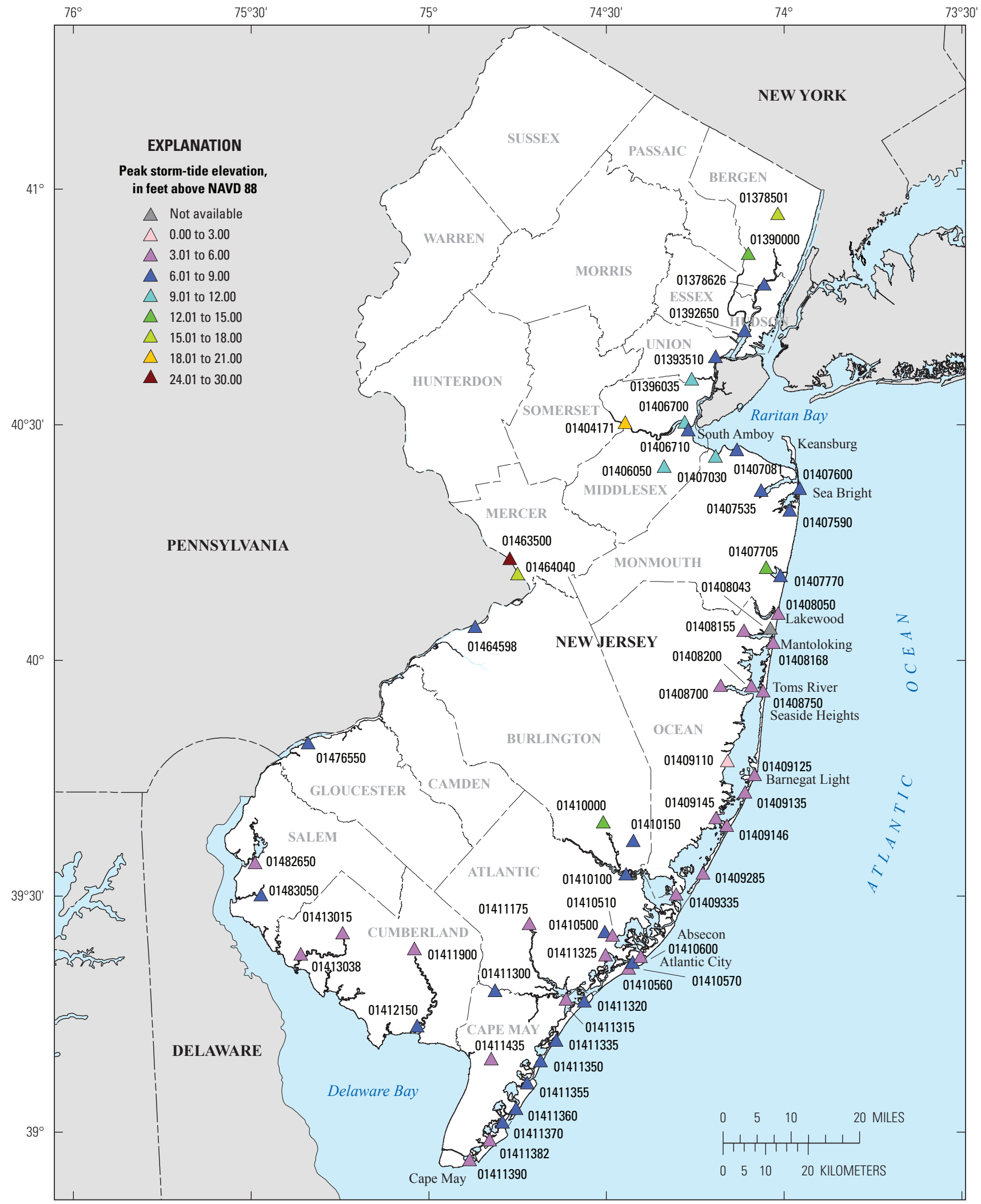

Base from the U.S. Geological Survey, NAD 1983

Universal Transverse Mercator, zone $18 \mathrm{~N}$ projection

Figure 4. Peak storm-tide elevations for real-time tide gages operated as part of the New Jersey Tide Telemetry Network. 

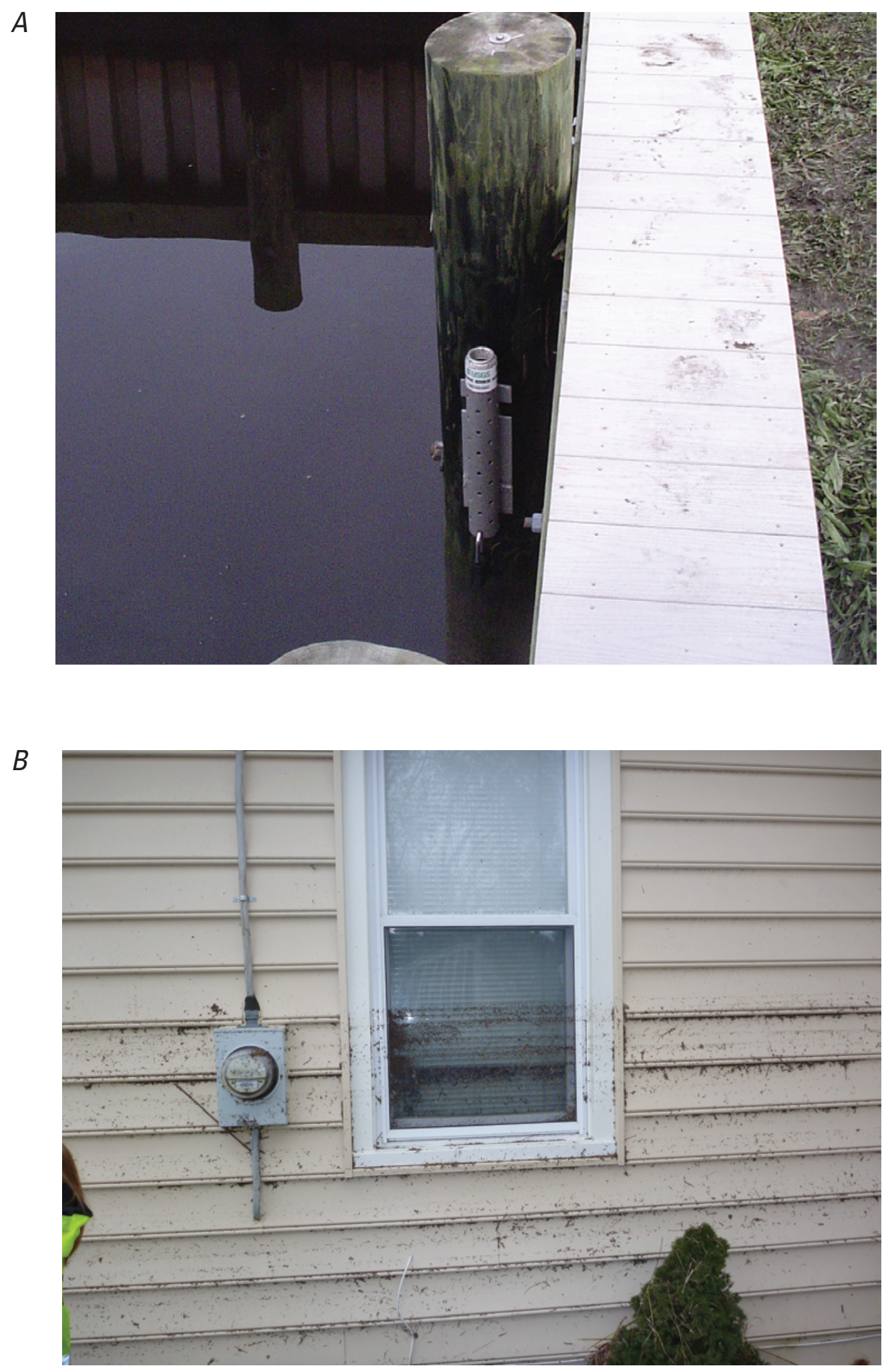

Figure 5. A, U.S. Geological Survey temporary storm-tide sensors deployed in protective metal housing to measure storm surge from Hurricane Sandy, and $B$, high-water mark on the side of a house along the coast of New Jersey produced by storm tide associated with Hurricane Sandy. ( $A$, photograph by U.S. Geological Survey personnel, $B$, photograph by M.R. Brady, U.S. Geological Survey) 
2-second data were used to estimate the elevation of the wave peaks associated with the storm tide. For this report, the wave height elevations are the total water-surface elevations of the wind driven waves. A 3-minute moving average was used to filter the raw data from these sensors to approximate a peak stillwater tide elevation at each temporary sensor location (fig 6). A 3-minute moving average was selected as a surrogate for the 3-minute averaging algorithm typically used by NOAA and USGS tide gages to compute tide elevations. The temporary sensor located near Sea Bright, N.J., site number SSS-NJ-MON-003WV, recorded a peak wave height elevation of more than $19 \mathrm{ft}$, which was the highest elevation recorded along the coast of New Jersey during this storm. The filtered peak-tide elevation for this temporary sensor was computed to be slightly less than $17 \mathrm{ft}$. The raw peak wave height elevations and filtered peak tide elevations for each temporary sensor are listed in table 4 (table 4, available online at http:// dx.doi.org/10.3133/sir20165085). The raw and filtered data are also presented graphically in figure 7 for the Sea Bright, N.J., storm-tide sensor. Figure 7 illustrates the envelope of unfiltered wave affected water-surface elevations that were measured in comparison to the filtered water-surface elevations computed to approximate storm-tide stillwater elevations.

In a coastal environment, the forces generated by waves are major stressors acting on roads, bridges, and structures. Storm-tide waves have the ability to erode dunes, destroy homes, and rip up docks, roadways, and bridge crossings. The damaging force of wind-driven waves was apparent to a new generation of coastal residences after Hurricane Sandy hit the coast of New Jersey because many homes were pushed off of their foundations or were completely destroyed (see appendix 2 for photos of storm damage). Simply measuring the tide elevation or doing statistical analysis of the peak water-surface elevations measured does not provide necessary information about the wave forms present during a storm that would be provided by spectral analysis of the data. In the mid-20th century, the method of time series analyses was introduced to oceanography. Since then many researchers have been inspired to apply time-series techniques to the analysis of random ocean waves. The use of spectral and statistical analysis was also introduced and used to analyze the properties of ocean waves (McCormick, 2010). Spectral analysis is typically used in the analysis of noise or ocean waves because it allows the individual wave harmonics to be broken out and analyzed separately.

In this study, the Fast Fourier Transform (FFT) method was applied to 2-second time-series data collected at the Sea Bright (MON-003WV), N.J., temporary wave-sensor location. The FFT computes the discrete Fourier transform faster than and produces the same result as if evaluating the definition directly. Using the FFT method, the 2-second data collected at Sea Bright, N.J., were analyzed, and several wave statistics were computed. The results of the analysis indicate that the average, or mean, wave height $\left(\mathrm{H}_{\mathrm{a}}\right)$ peaked at about $2.4 \mathrm{ft}$, the significant wave height $\left(\mathrm{H}_{\mathrm{s}}\right)$ peaked at about $3.8 \mathrm{ft}$, and the expected maximum wave height $\left(\mathrm{H}_{\mathrm{m}}\right)$ peaked at about $7.1 \mathrm{ft}$ in the early morning hours of October 30, 2012. The term average wave height refers to the average wave height calculated over the entire sample, and the significant wave height refers to the average height of the highest one-third of waves. The computed timing statistics indicate that the estimated mean wave period gradually increased from about 5.7 seconds to about 6.6 seconds and that the crest period remained relatively constant at about 5.2 seconds. The period ( $t$ ) of a wave is the time needed for one complete cycle of a wave to pass a given point. The crest period is the time between successive wave crests (or troughs) passing a given point. These timing statistics are an estimate of the average wave period and the wave crest period. The importance of including these data in this report is related to the data collection location. Wave data typically are collected by ocean buoys; the buoys measure a wide range of wave heights. As waves move closer to shore they become smaller, and eventually many of them break along the shoreline. In this case, the wave sensor was mounted to a support structure over land or at the coastline; it recorded the maximum significant wave height (Hs) at $3.8 \mathrm{ft}$ and the maximum wave height $\left(\mathrm{H}_{\mathrm{m}}\right)$ at $7.1 \mathrm{ft}$, as indicated above. The NOAA Wavewatch III simulations indicated that the highest significant waves during Hurricane Sandy were 13.7 meters $(\mathrm{m})$ in the open ocean and decreased to $9 \mathrm{~m}(32 \mathrm{ft})$ in shallower waters near the entrance to the New York Harbor (National Oceanic Atmospheric Administration, 2015c). The ability to measure and calculate these wave statistics near shore and over land during inundation could provide benefits for future FEMA coastal flood insurance studies and Federal, state, and private development near the coast. These data may help to validate the wave analysis that FEMA mapping partners perform as part of a flood insurance study and provide valuable information about the forces acting on buildings, roads, bridges, and other structures along the coast, leading to better design of infrastructure for the future.

Wave height and period statistics are presented in figure 8 . These data were collected at 2 -second intervals. Collecting data at a 1 -second or faster interval would provide more measurements of the wave action and could produce a better estimate of the actual wave heights. Although this dataset is slightly coarse, and therefore conservative, it was analyzed and is presented to inform the reader as an estimate of the waves and forces acting on the coast of New Jersey during this storm. The processing of the raw data and application of the FFT was done by Harry Jenter and his team of the USGS National Research Program and Michael Lee of the USGS (Michael Lee, USGS, written comm., 2015).

\section{Peak Storm-Tide Elevations from USGS High- Water-Mark Data}

The morning after Hurricane Sandy made landfall, USGS field crews were deployed to mark and survey HWMs along the North Atlantic coast of the United States. These efforts were performed in cooperation with FEMA Region II and 


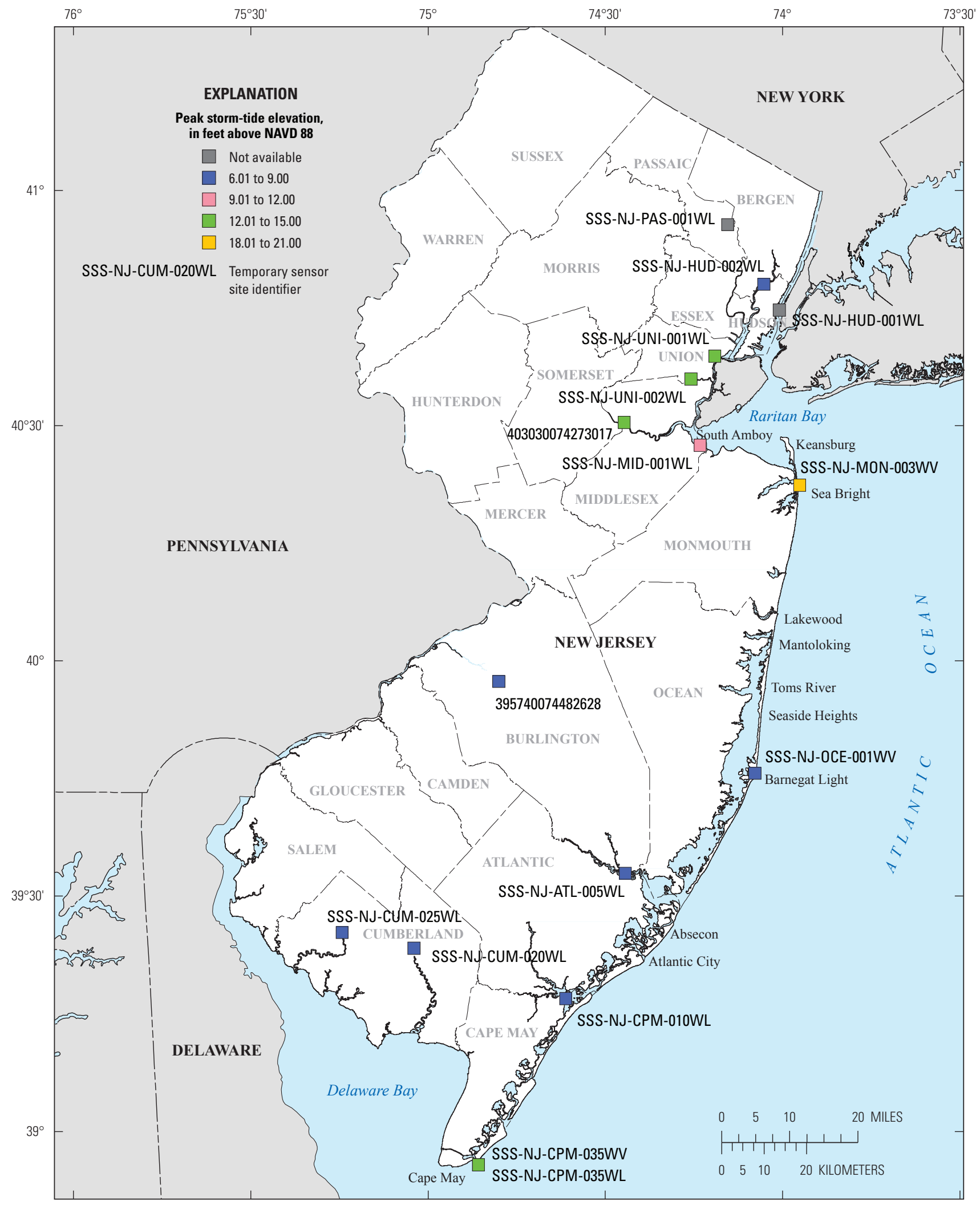

Base from the U.S. Geological Survey, NAD 1983

Universal Transverse Mercator, zone 18N projection

Figure 6. Peak storm-tide elevation for U.S. Geological Survey temporary storm-tide sensors deployed along the New Jersey coast. 


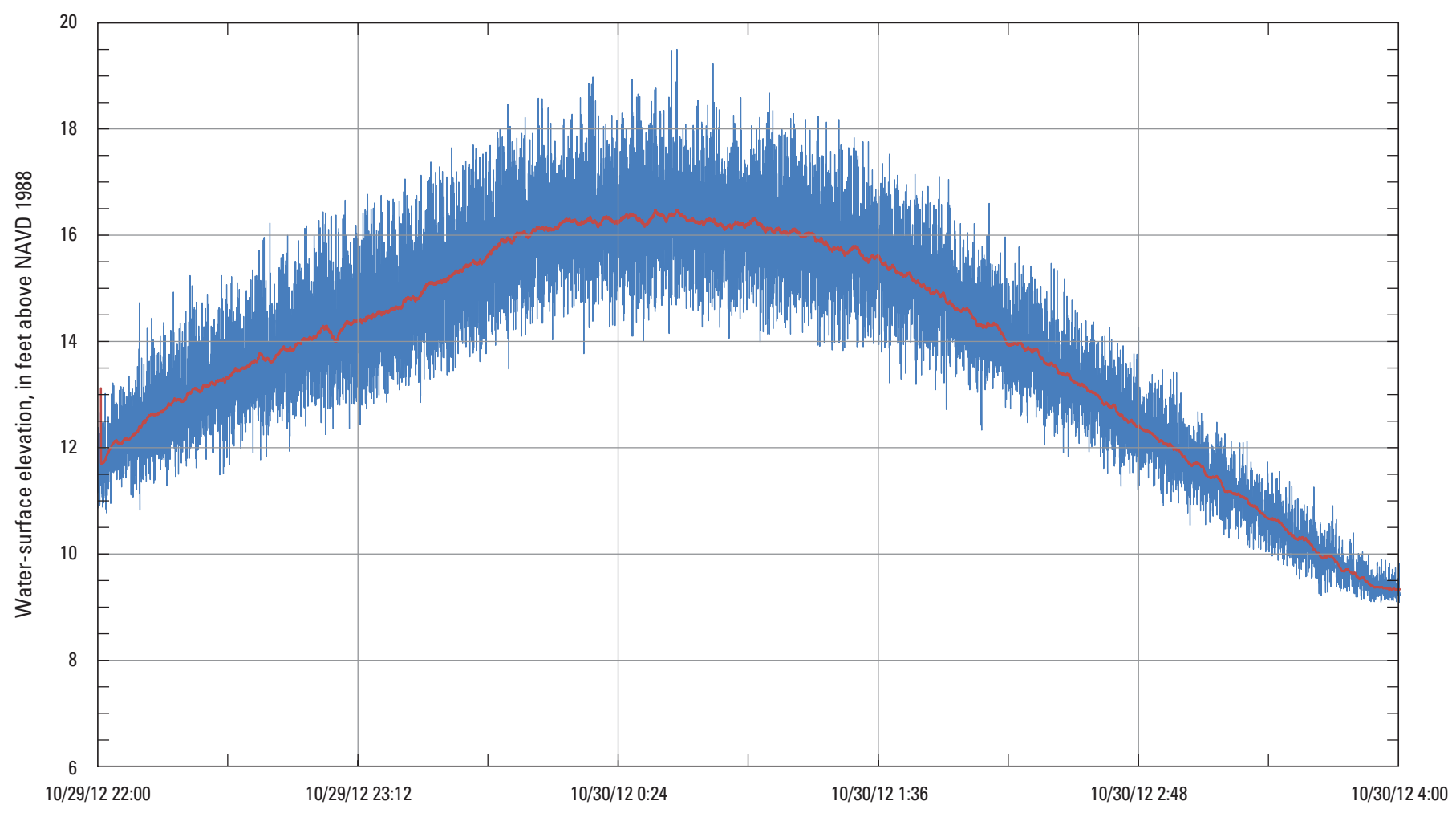

EXPLANATION

Water-surface elevation, in $\mathrm{ft}$ ( 2 second readings) __ _ Filtered water-surface elevation, in $\mathrm{ft}$ (3-minute average)

Figure 7. Water-surface elevation data collected at a 2-second interval and filtered 3-minute average storm-tide elevations at U.S. Geological Survey storm-tide and wave sensor, SSS-NJ-MON-003WV, Sea Bright, NJ, October 29-30, 2012.

NJDEP in New Jersey. The USGS identified, flagged, and surveyed more than 600 HWMs along the Atlantic coast. HWMs were identified, flagged, and surveyed at 169 sites in New Jersey alone (fig. 9). HWMs are evidence of the highest elevation reached by a flood (Benson and Dalrymple, 1967). HWM elevation data have many uses, including assessing the accuracy of flood insurance study elevations, verifying peak recorder readings, verifying depth and extent of inundation, and calibrating of future hydraulic models. The data collected from this effort were used by FEMA to create a reliable map that shows coastal areas inundated by Hurricane Sandy. In addition, the HWM data document the peak storm-tide elevation, extent of flooding, and damage in many communities along the coast; the data can be used as a reference by planners, emergency managers, builders, and homeowners to hopefully build a more resilient community in the wake of this major coastal flood. In New Jersey, the HWM data indicate that the highest storm-tide elevations were recorded along the northern coastline from about Toms River north through Raritan Bay toward Bergen County (fig. 9). In general, peak storm-tide elevations of about $10 \mathrm{ft}$ to as much as 12 or $13 \mathrm{ft}$ were recorded from Sea Bright north to Sandy Hook (fig. 1) and along the coast of Raritan Bay and Staten Island, New York.

The HWMs were flagged and surveyed using Global Navigation Satellite System survey equipment and techniques, and elevations were referenced to NAVD 88. The HWMs were reported with an accuracy qualification of "excellent," "good," "fair," or "poor," in accordance with the guidelines of Benson and Dalrymple (1967). In a riverine environment the qualification of "excellent" has been defined to mean the reported HWM is considered to be within $0.02 \mathrm{ft}$ of the true elevation, "good" is considered to be within $0.05 \mathrm{ft}$, and "fair" is considered to be within $0.10 \mathrm{ft}$. "Poor" implies less than "fair" accuracy (Suro and others, 2009). During this coastal data collection effort the HWM field forms were modified to increase the uncertainty of the classifications as follows: "excellent" is within $0.05 \mathrm{ft}$, "good" is within $0.10 \mathrm{ft}$, "fair" is within $0.25 \mathrm{ft}$, and "poor" is less than "fair" quality. A summary of the HWM data collected is presented in table 5 (table 5, available online at http://dx.doi.org/10.3133/sir20165085). 


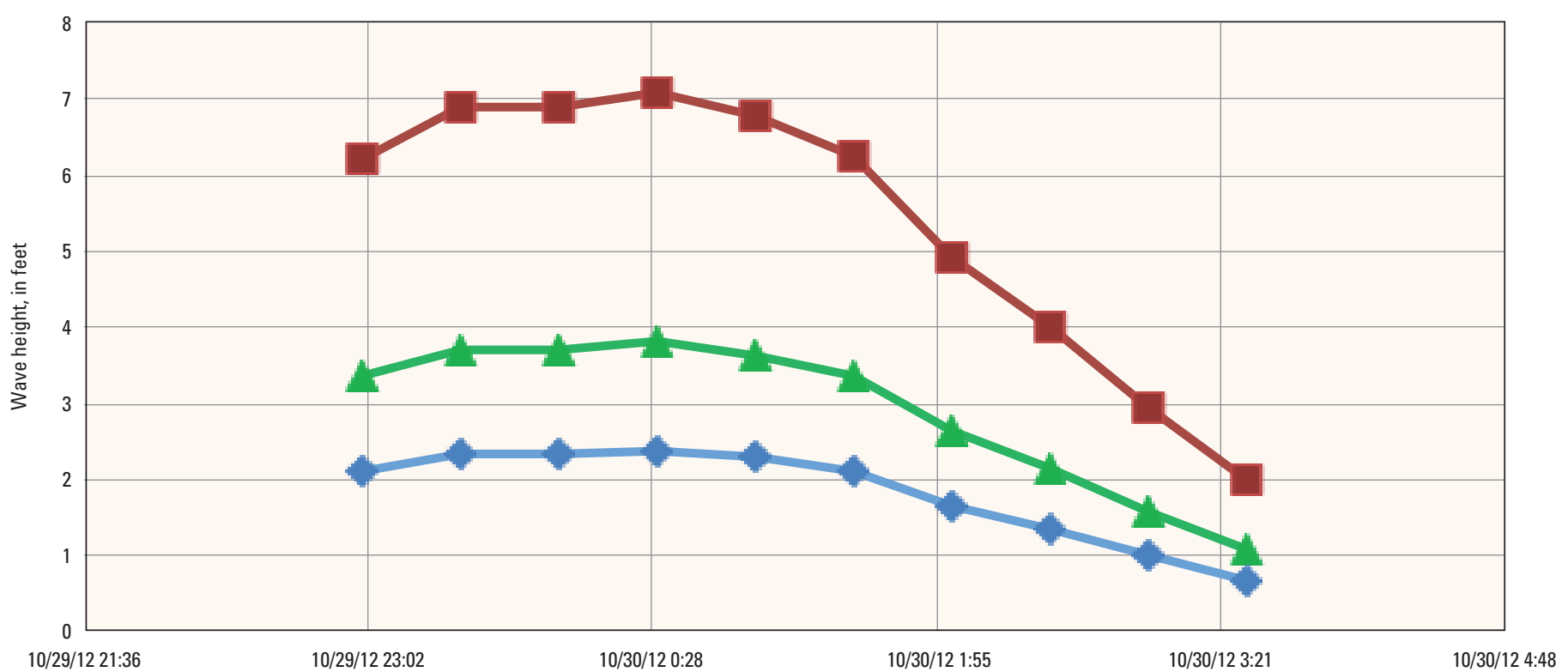

EXPLANATION

Average wave height $(\mathrm{Ha}) \rightleftharpoons$ Expected maximum wave height (Hmax) $\quad$ Significant wave height (Hs)

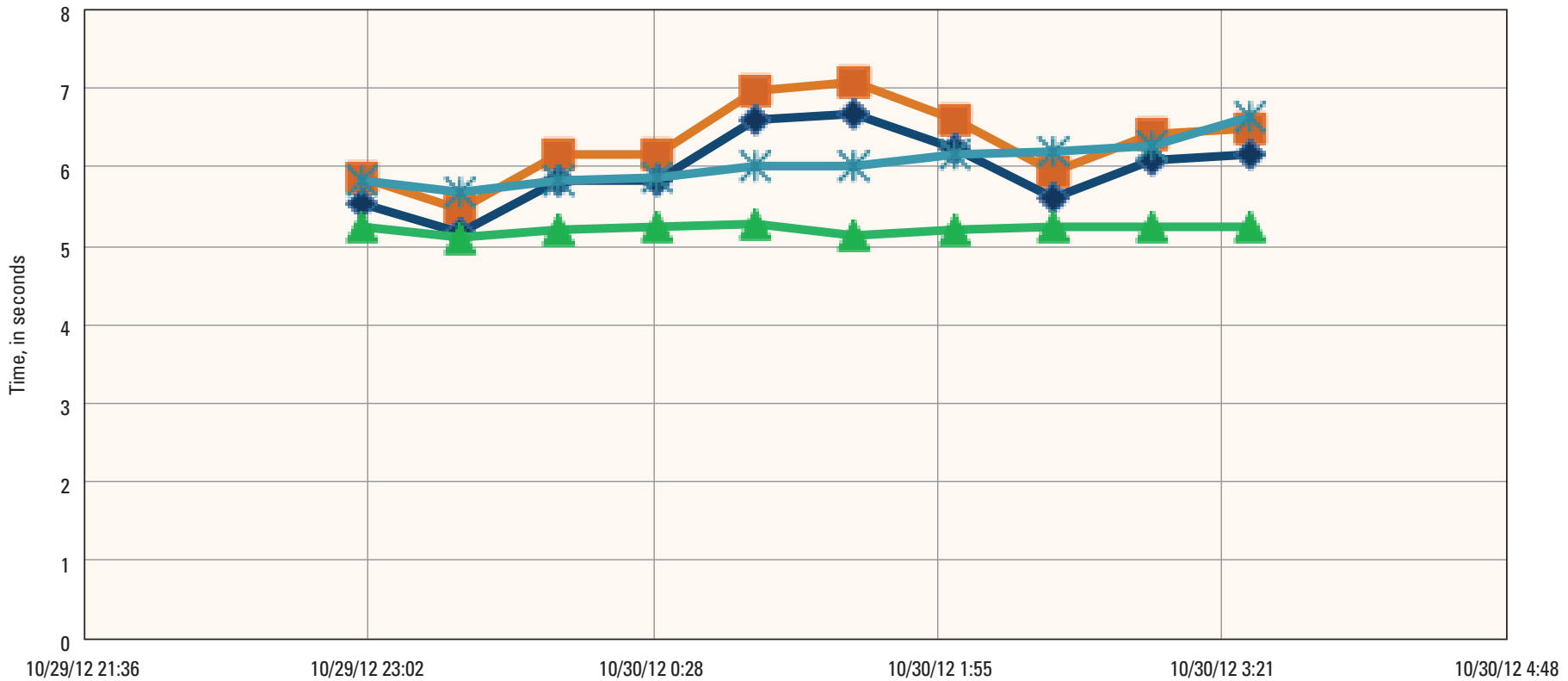

EXPLANATION

Mean wave period (Tv) $\longrightarrow$ Significant wave period (Ts) $\longrightarrow$ Peak wave period (Tp)

Figure 8. Wave statistics computed from 2-second data collected at U.S. Geological Survey storm-tide and wave sensor, SSS-NJMON-003WV, Sea Bright, NJ, October 29-30, 2012, using experimental spectral analysis tool. (Data processed by spectral analysis tool developed by USGS Texas Water Science Center) 


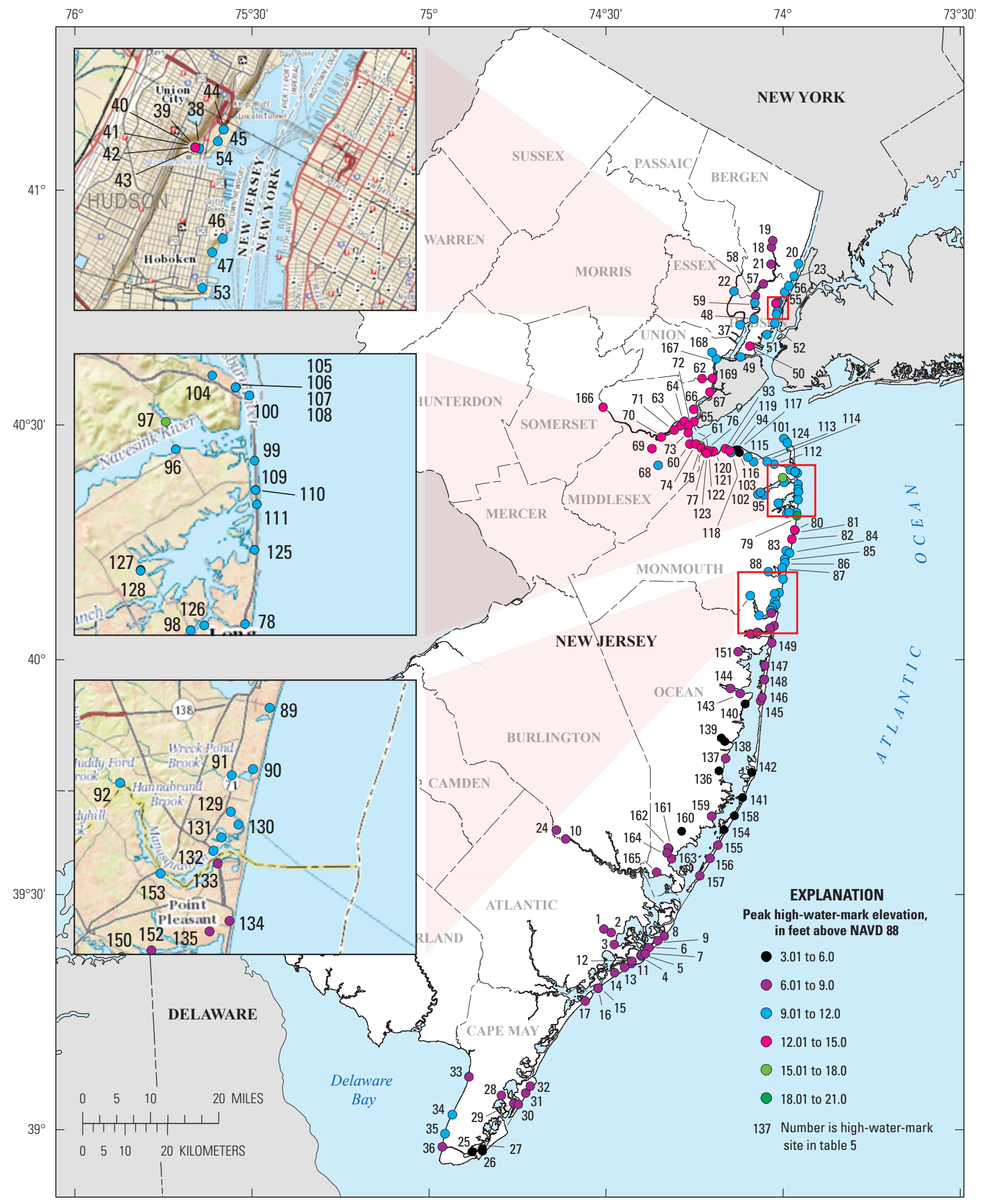

Base from the U.S. Geological Survey, NAD 1983

Universal Transverse Mercator, zone 18N projection

Figure 9. Peak storm-tide elevations at selected high-water-mark sites along the coast of New Jersey for the coastal flood of October 29-30, 2012. 


\section{Comparison to Historic Storms}

The effects of Hurricane Sandy were not uniform along the coast of New Jersey, as can be expected. Most storms are unique but often times produce similar results. Peak storm-tide elevations associated with Hurricane Sandy were much higher along the northern coast of New Jersey than along the southern coast. This section presents a general comparison of the flooding associated with Hurricane Sandy along the coast of New Jersey with flooding documented for other coastal storms that caused major damage along the coast of New Jersey in the past 100 years.

\section{Hurricane Irene, 2011}

Hurricane Irene was a large and intense storm that originated off the west coast of Africa on August 15, 2011. The storm intensified into a hurricane when it passed over the island of Puerto Rico and continued to move west-northwest. As the storm moved away from the coast of Hispaniola on August 24, it strengthened to a Category 3 hurricane. A trough developed over the eastern United States on August 24, which helped to steer the hurricane north-northwest across the Bahamas and toward the United States. Hurricane Irene passed well off the coast of Florida and Georgia but made its first landfall as a Category 1 hurricane near Cape Lookout, North Carolina. It continued on a generally northern track and made the second landfall just north of Atlantic City near Little Egg Harbor, N.J., on August 27, 2011 (fig. 10).

Although the time at which Hurricane Irene weakened to a tropical storm is a matter of technical debate, assuming it was still a hurricane when it made landfall in New Jersey would make it the first hurricane to make landfall in New Jersey since 1903. The effects from Hurricane Irene were catastrophic because of the magnitude of rain that it funneled into the region. More than 10 inches of rain was reported during the storm in many locations in New Jersey, and the average statewide monthly rainfall total exceeded 17 inches at several locations, making August 2011 the wettest August in history for these locations. It was also the wettest summer in New Jersey history, exceeding the previous record set in 1928 (Office of the State Climatologist, 2011). This differs dramatically from the effects of Hurricane Sandy in 2012. Hurricane Sandy was a major offshore hurricane that produced major damage with its sustained high winds that drove tidal water-surface elevations to new records.

The effects of Hurricane Irene are documented in a report by Watson and others (2013). Peak storm-tide elevations for selected historic storms recorded at USGS tide gages and tidal crest-stage gages are listed in table 6 (table 6 , available online at http://dx.doi.org/10.3133/sir20165085). The National Weather Service map of total observed precipitation associated with Hurricane Irene for the 24-hour period ending on August 28, 2011, shows general rainfall totals of greater than 6 inches throughout most of New Jersey (fig. 11). The major difference in rainfall patterns between Hurricanes Irene and Sandy is reflected in the type and extent of flood damages documented for each storm. Hurricane Irene produced major widespread flooding throughout New Jersey, whereas Hurricane Sandy produced extensive coastal storm-surge flooding and damage.

\section{December 1992, The Great Nor'easter}

An intense, slow-moving nor'easter storm hit the eastern coast of New Jersey during December 11-12, 1992, producing strong winds that gusted at times to hurricane strength and caused record, to near record flooding, along the entire coast of New Jersey from Bergen County to Cape May (Suro, 1998). Many New Jersey counties were declared disaster areas by President George H.W. Bush. Millions of dollars in damages were reported, and two deaths were attributed to the storm. The northern parts of New Jersey sustained the most extensive flooding and high observed storm-tide elevations as a result of the timing of the normal tide cycle and the peak storm tide. The peak storm surge occurred near low tide at Cape May but near high tide at Sandy Hook (fig. 12). The USGS collected storm-tide data at 1 streamgage, 2 tide gages, and 11 tidal crest-stage gages during the 1992 storm. In addition, HWMs were flagged and surveyed at about 82 sites to document the effects of the major coastal flooding from the December 1992 nor'easter. The peak storm-tide elevations associated with the 1992 nor'easter for 15 stations are summarized by Suro (1998).

The December 1992 nor'easter presented the longest continued battering of the New Jersey coastline. Three consecutive high tides $(6.5 \mathrm{ft}, 5.5 \mathrm{ft}$, and $5.5 \mathrm{ft})$ at Sandy Hook, N.J., exceeded the high tides that occurred during the "Five High" storm of March 1962 (fig. 13). The HWMs flagged and surveyed after the December 1992 nor'easter have not been previously published, but those original HWMs are included in this report (table 7, available online at http:// dx.doi.org/10.3133/sir20165085; fig. 14) for documentation and comparison to peak tide elevations from Hurricane Sandy. A few of the HWMs flagged and surveyed in 1992 were removed from table 7 because the elevations were considered unreliable and could not be verified. Table 7 includes the location, description, and elevation of 82 HWMs flagged and surveyed in 1992 to document the flooding associated with the December 1992 nor'easter. The HWMs resulting from Hurricane Sandy were generally 1-3 ft higher than those from the 1992 nor'easter, except in areas of Monmouth County and northward into Hudson and Essex Counties where the peaks from Hurricane Sandy were more than $3 \mathrm{ft}$ higher than those documented after the December 1992 storm. Peak storm-tide elevations from selected HWMs in 1992 and nearby HWMs flagged and surveyed after Hurricane Sandy (October 2012) illustrate the differences between these two storms. All elevations for the December 1992 event were originally referenced to National Geodetic Vertical Datum of 1929 (NGVD 29) and have been converted to the North American Vertical Datum 


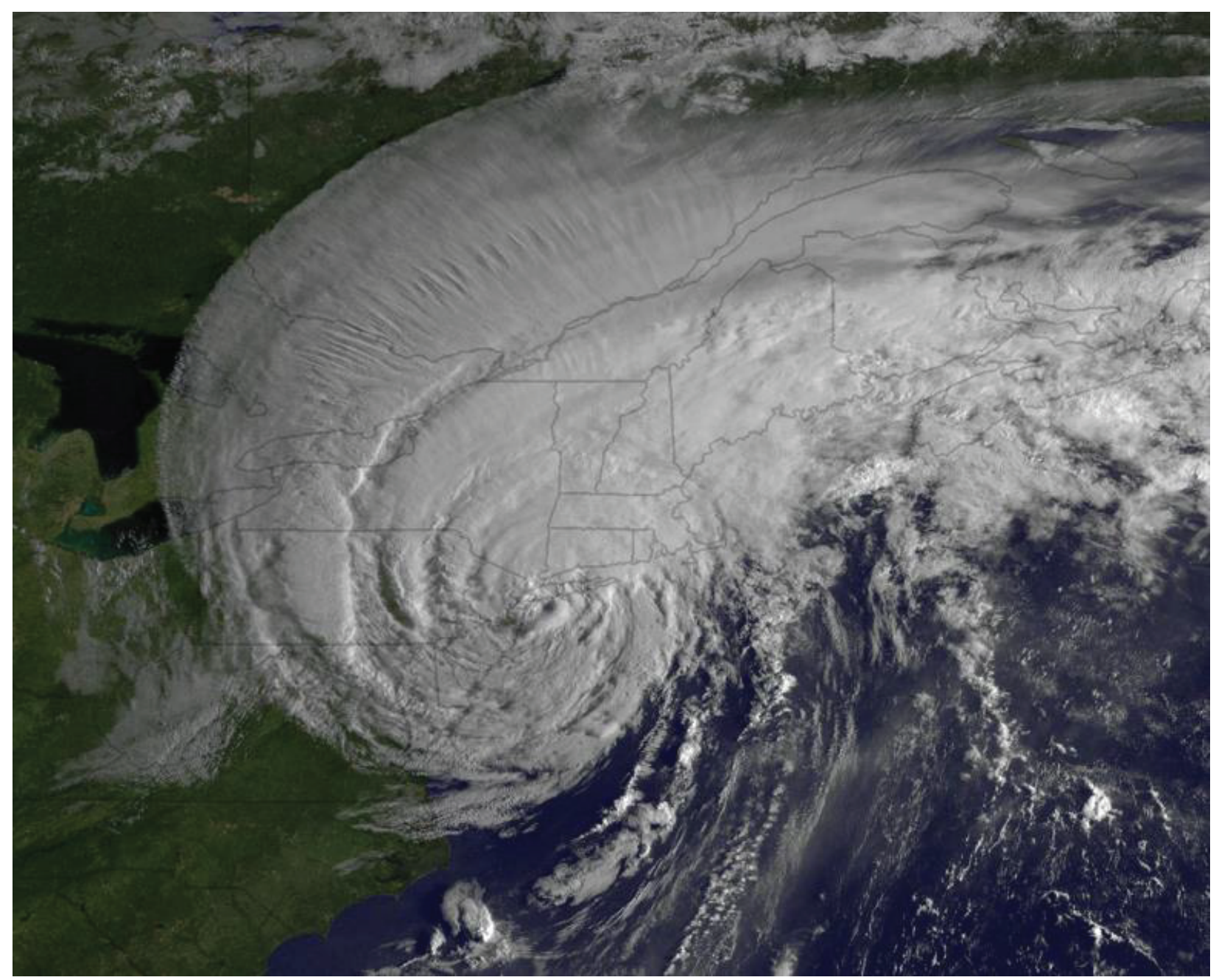

Figure 10. Satellite image of Hurricane Irene, August 28, 2011, as it was making landfall near New York City. Photograph courtesy of National Oceanic and Atmospheric Administration.

of 1988 (NAVD 88) using VERTCON for this report. VERTCON is a National Geodetic Survey (NGS) Height Conversion program that computes the modeled difference in orthometric height between NAVD 88 and the NGVD 29 for a given location specified by latitude and longitude (National Oceanic and Atmospheric Administration, 1999). Peak storm-tide elevations from Hurricane Sandy exceeded those recorded during the December 1992 nor'easter at 15 gages (Suro, 1998) and at more than 90 percent of the HMW sites originally flagged and surveyed after the 1992 nor'easter (table 7; fig. 14).

\section{March 1962 Five-High Storm}

The storm of March 6-8, 1962, was one of the most complex and unexpected storms to hit the coast. The storm was essentially classified as a slow moving extratropical coastal storm. Combined with spring tides, the March 1962 storm produced tremendous destruction of the coastal infrastructure from southern New England to Florida (U.S. Army Corps of Engineers, 1963). The term extratropical is used when describing hurricanes or cyclones that have lost their tropical characteristics or have weakened. The storm had gale force winds that at times increased to hurricane strength, which in itself is not uncommon for a winter extratropical cyclone, but what made this storm quite unusual was the accompanying surge that occurred in many locations during 4 or 5 successive high tides over a period of about 48 hours. This resulted in this storm being referred to as the "Five-High" storm that created major tidal flooding and extensive erosion due to the continuous onslaught of wind-driven waves on the shoreline.

The NOAA tide gage at Sandy Hook, N.J., indicated a peak storm-tide elevation from hourly data of $6.57 \mathrm{ft}$ on March 6,1962 . This peak was equal to the peak storm tide from the Great Atlantic Hurricane, which produced a peak of $6.57 \mathrm{ft}$ (NAVD 88) on September 14, 1944, but less than the 7.27-ft (NAVD 88) peak storm tide from the September 12, 1960, 


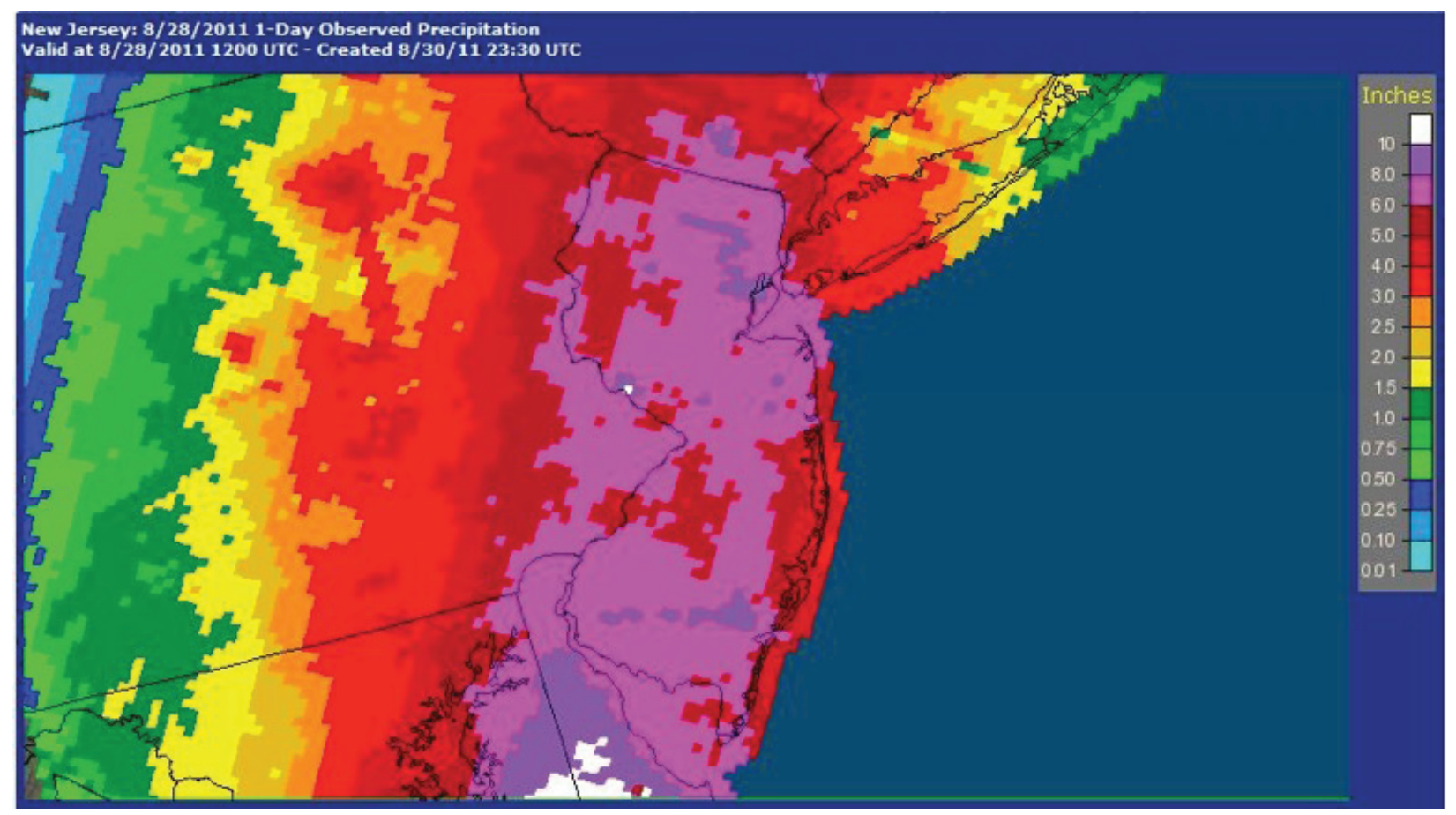

Figure 11. National Weather Service map of total observed precipitation in New Jersey and vicinity for 24-hour period ending August 28, 2011, at 0800 hours eastern daylight time. (Courtesy of National Weather Service)

storm and the $7.26 \mathrm{ft}$ (NAVD 88) peak storm tide from the December 1992 nor'easter (National Oceanic and Atmospheric Administration, 2013). The difference is due to the extent of wind-driven storm tide and surge. For the March 1962 storm, there were three consecutive high tides during March 6-7 that exceeded $6.0 \mathrm{ft}$. (NAVD 88). The fourth and fifth consecutive high tides exceeded $5.5 \mathrm{ft}$ and $4.5 \mathrm{ft}$, respectively, on March 7 and 8 (fig. 13). The consistent battering of the coastline caused some of the most extensive damage ever documented along the New Jersey coast at the time.

\section{Older Historic Coastal Storms}

At the time, the March 1962 Five-High storm was compared to previous storms like Hurricane Donna in 1960, the Great Atlantic Hurricane of 1944, or the Hurricanes of 1933 and 1938. Sparse data are available for these older historic storms. The U.S. Army Corps of Engineers report documenting the March 1962 storm (U.S. Army Corps of Engineers, 1963) refers to the tide gage at Sandy Hook, N.J., which recorded a peak during the 1962 storm that was about $1 \mathrm{ft}$ lower than the Hurricane Donna 1960 peak. South of New Jersey in Ocean City, Maryland, the peak-tide elevation for the 1962 storm was documented as being $1.5 \mathrm{ft}$ higher than the 1933 hurricane peak-tide elevation.

The publication "Seven Superstorms of the Northeast" (Turner, 2005) describes the Great Atlantic Hurricane of 1944, the Great New England Hurricane of 1938, the Two August Hurricanes of 1893, and Redfield's Hurricane of 1821. The 1944 hurricane was considered the strongest of those mentioned with the possible exception of the 1821 storm. The 1944 storm spared New Jersey a direct hit; unlike Hurricane Sandy, it passed along the coast of New Jersey. The eye of the storm was about 35 miles from southern New Jersey and 50 to 75 miles east of Long Branch, N.J., and New York City, respectively, as it curved away from the coast. The 1821 storm was reported to have followed a route up the coast of New Jersey over what is now the Garden State Parkway.

The peak storm-tide elevations from Hurricane Sandy exceeded those documented after the 1960 and 1962 storms at several locations along the coast of New Jersey. If historic observations are accurate, the Redfield Hurricane of 1821 was the only storm noted to be greater, or more damaging, than the others mentioned and potentially the most comparable to Hurricane Sandy in terms of historic documentation of damages along the coast of New Jersey. 
$A$

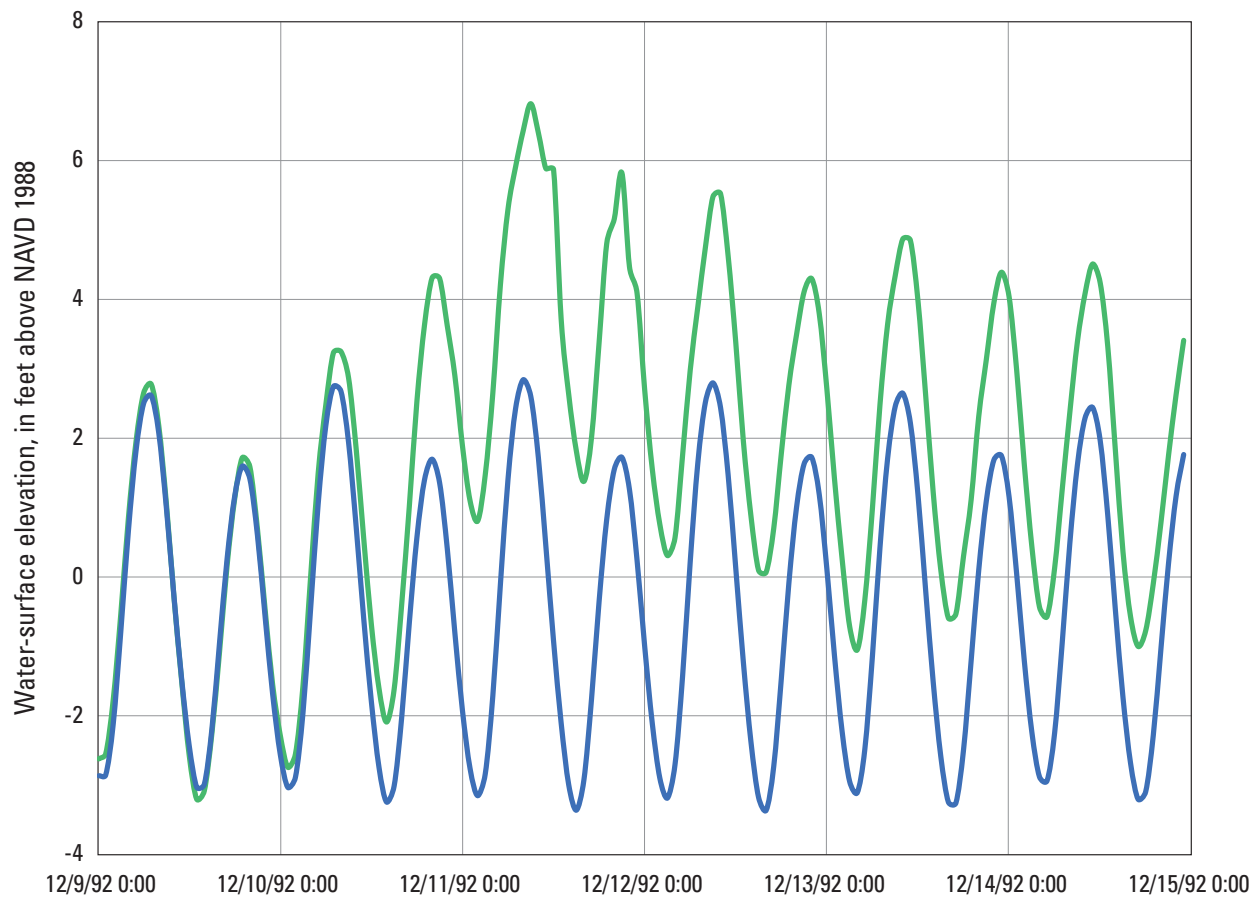

$B$

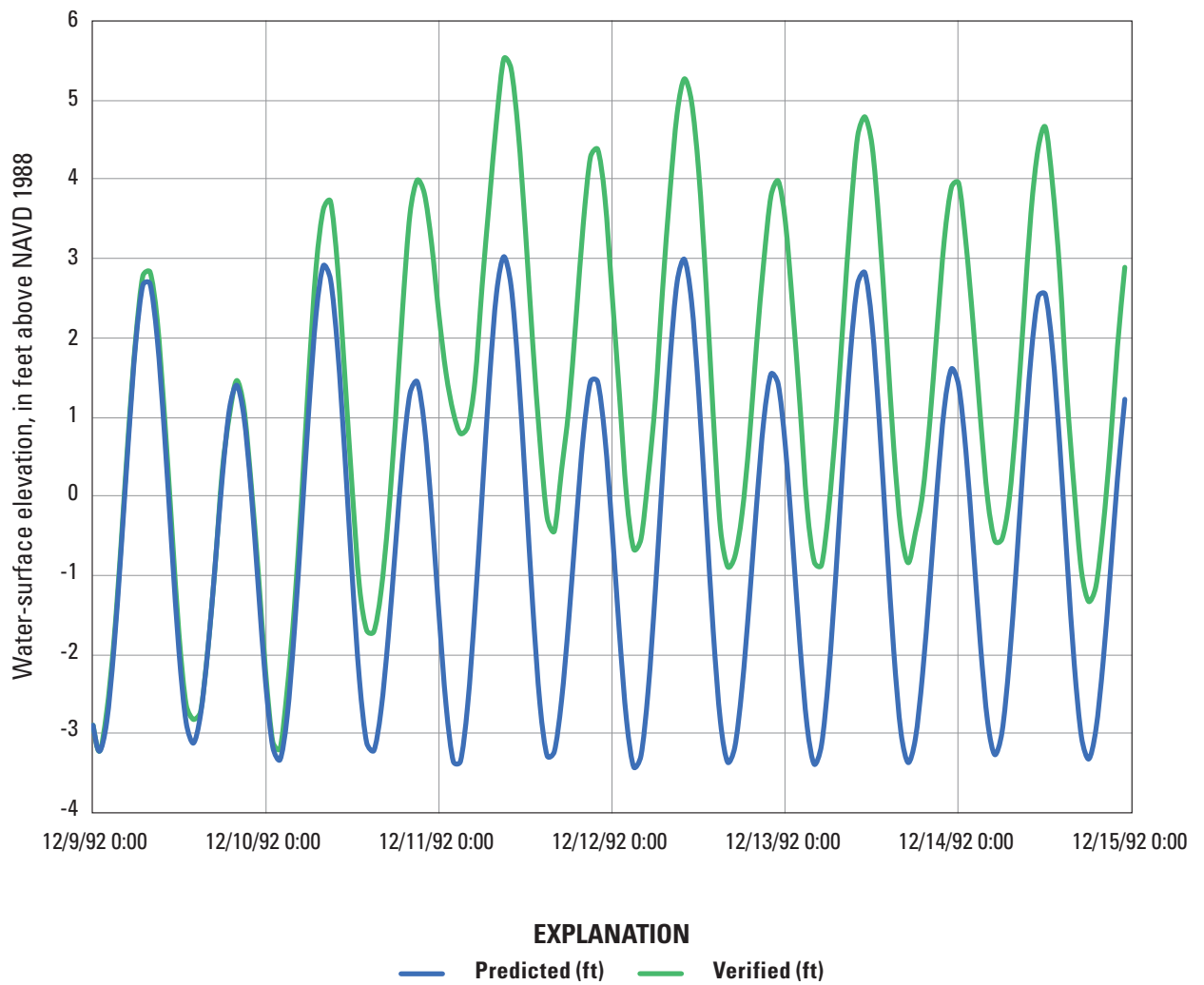

Figure 12. Hourly tide elevations at National 0 ceanic and Atmospheric Administration tide gages at $A$, Sandy Hook and $B$, Cape May during the December 1992 nor'easter storm, December 9-14, 1992. Predicted elevations are the original National Oceanic and Atmospheric Administration (NOAA) predicted tides, and the verified elevations are the actual observed (recorded) tide elevations. (Data courtesy of NOAA. NAVD 88, North American Vertical Datum of 1988) 


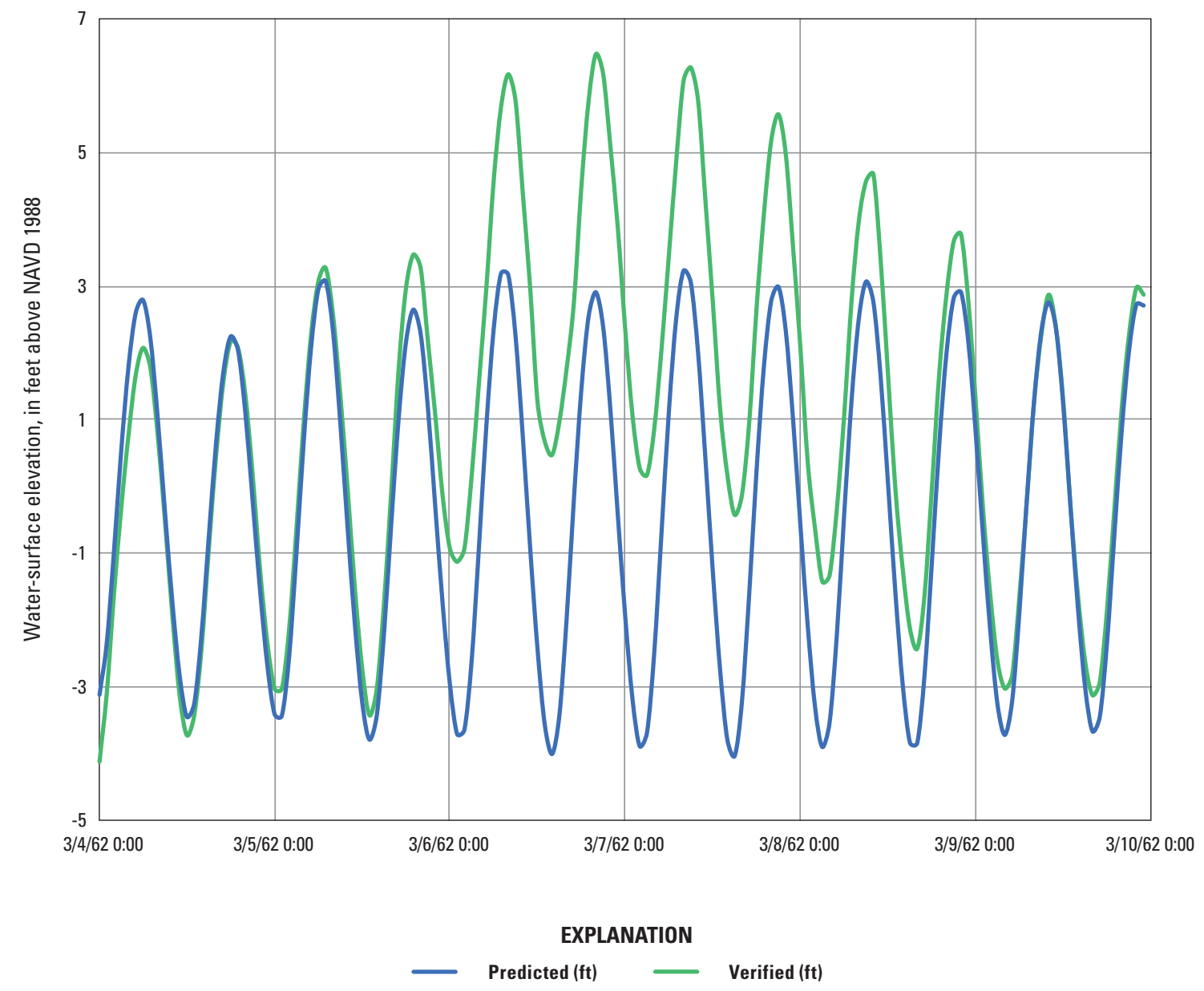

Figure 13. Hourly tide elevations at National Oceanic and Atmospheric Administration tide station at Sandy Hook, NJ, during the March 1962 “Five High" storm. (Data courtesy of NOAA. NAVD 88, North American Vertical Datum of 1988) 


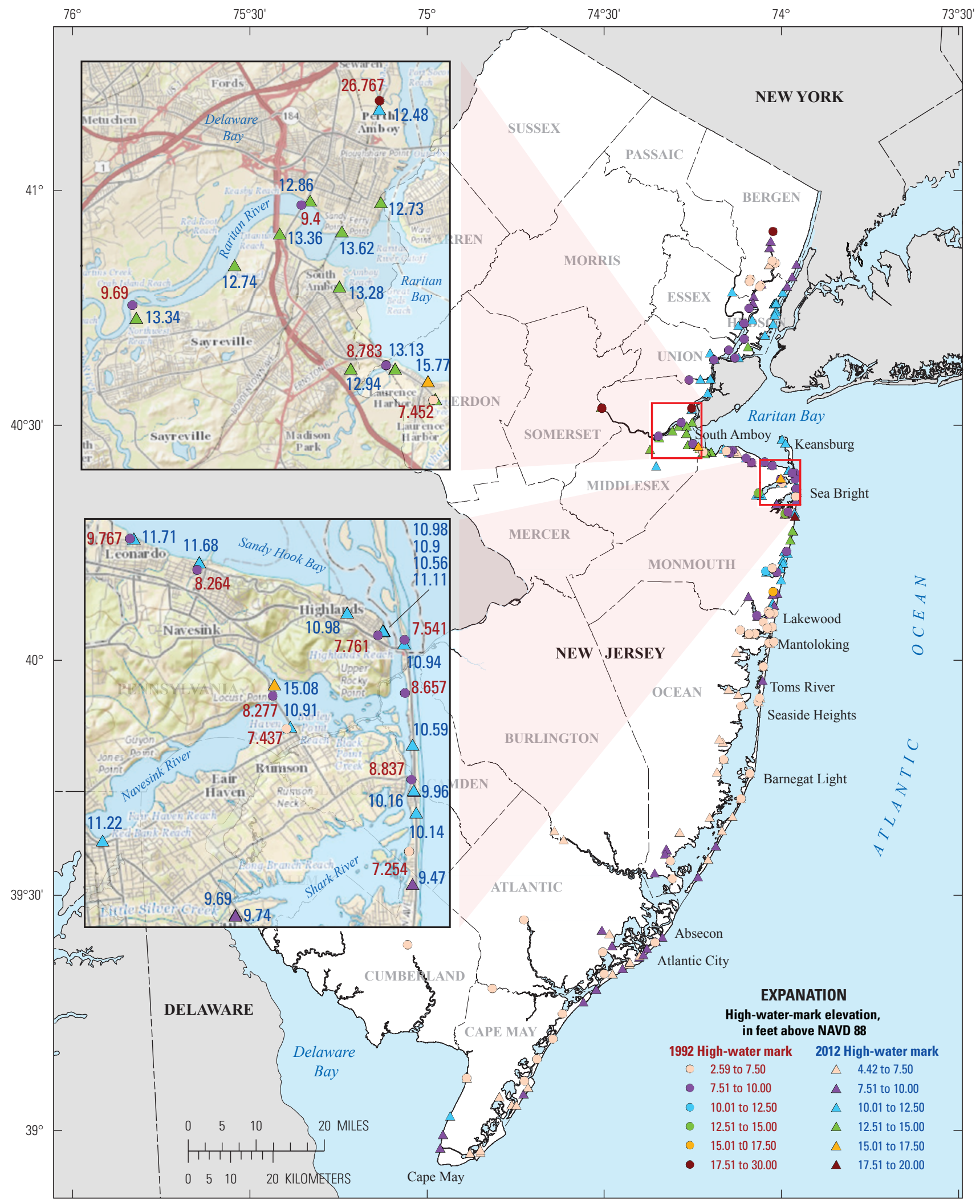

Base from the U.S. Geological Survey, NAD 1983

Universal Transverse Mercator, zone 18N projection

Figure 14. Location and elevation of high-water marks flagged and surveyed after the December 1992 nor'easter storm and selected nearby high-water marks from Hurricane Sandy, October 29-30, 2012, along the coast of New Jersey. 


\section{Flood Frequency Comparison and Analysis}

\section{Estimated Exceedance Probabilities for Peak Storm-Tide Elevations from Hurricane Sandy}

FEMA began the process of updating flood insurance studies for 14 coastal counties in New Jersey and New York City as part of the Risk Map program long before the tropical depression that later intensified into Hurricane Sandy developed (Federal Emergency Management Agency, 2013a). In October 2012, when Hurricane Sandy hit the New Jersey coast, the updated FEMA coastal flood insurance study was only partially complete and still needed overland wave modeling and erosion analysis to be completed. As part of a typical coastal flood insurance study, FEMA often uses a hydrodynamic circulation model like the Advanced Circulation model (ADCIRC) developed by Dr. Rick Luettich at the University of North Carolina at Chapel Hill, Institute of Marine Sciences, and by Dr. Joannes Westerink at the University of Notre Dame, Department of Civil Engineering and Geologic Sciences, and the Simulating Waves Nearshore (SWAN) model developed at Delft University of Technology to compute stillwater elevations for the 10-, 2-, 1-, and 0.2-percent annual chance flood events for coastal communities. Although the additional erosion and overland wave modeling had not yet been done, there was enough change in the newly predicted stillwater elevation data that FEMA felt confident in issuing advisories referenced to the new stillwater modeling to provide community officials and the public with the best available data for planning and rebuilding.

The modeling analysis computed stillwater elevations for the 10-, 2-, 1- and 0.2-percent annual chance floods for the coastal communities of New Jersey and New York City. The FEMA flood insurance study preliminary stillwater flood elevations were used by the USGS to estimate the recurrence intervals, in years, and the annual exceedance probability, in percent, for the documented peak storm-tide elevations associated with Hurricane Sandy. HWMs were flagged and surveyed at 169 locations along the coast of New Jersey to document the peak storm-tide elevations associated with Hurricane Sandy. Most of these marks were flagged and surveyed in areas of low wave action to best represent a stillwater elevation for direct comparison to the modeled stillwater elevations. During the review process a few HWMs were determined to have been affected by moderate waves and were therefore excluded from the frequency comparison. These HWMs are presented in table 5, but they are listed without an associated annual exceedance probability. Peak water-surface elevations from USGS tide gages were used directly in the computation of recurrence interval because it was assumed that the wave dampening plates on the gage intakes combined with the NOAA filtering algorithm used in the data collection process produced a record comparable to modeled stillwater elevations. Storm-surge sensor data were not filtered during data collection, so the raw data are not directly comparable to modeled stillwater elevations. A 3-minute moving average filter was applied to the storm-surge sensor data to approximate a stillwater value and allow for comparison to the modeled stillwater elevations in the coastal flood frequency analysis.

The coastal flood frequency analysis to estimate the peak storm-tide elevations with an annual exceedance probability of 10-, 2-, 1-, and 0.2-percent were computed by FEMA contractors using guidelines updated after Hurricane Katrina. The USGS used the statistical water-level data provided by Risk Analysis Mapping and Planning Partners (RAMPP). RAMPP are engineering consultants hired by FEMA as mapping partners that prepared the analysis that was used to delineate the Special Hazard Area Zones for the Preliminary Coastal Flood Insurance Studies produced for the New Jersey and New York City areas (Federal Emergency Management Agency, 2013a). The special flood hazard area is generally the area covered by water when the water-surface elevation is equal to the base flood elevation. The base flood elevation (BFE) in an A-zone is the water-surface elevation that has a 1-percent annual chance of exceedance (or the 100-year flood elevation), and in a coastal V-zone, it is the wave-affected 1-percent annual chance of exceedance elevation.

The USGS performed an analysis comparing peak storm-tide elevation data from USGS tide gages and HWM sites (that were considered to be minimally affected by waves) along the New Jersey coast for Hurricane Sandy and computed an estimated annual exceedance probability, or recurrence interval, for each location. Results of the comparison of peak storm-tide elevations associated with Hurricane Sandy indicate that locations along the northern coast of New Jersey from southern Monmouth County north toward Sandy Hook and into Raritan Bay had documented peak storm-tide elevations of greater than the 100-year recurrence interval (exceeded the 1-percent annual chance flood elevation). Some locations in Monmouth County, in the areas of Long Branch and Sea Bright, were among those that experienced peak storm-tide elevations that equaled or exceeded the 500-year recurrence interval (exceeded the 0.2-percent annual chance elevation). Farther south along the New Jersey coast (from the areas near Lakewood south to Atlantic City) peak storm-tide elevations generally ranged from greater than a 100-year recurrence interval (less than 1-percent annual chance elevation) to about a 50-year recurrence interval (2-percent annual chance elevation). The communities near Atlantic City south to Cape May generally had peak storm-tide elevations associated with recurrence intervals ranging from about 50 years to less than 10 years (2-percent to 10-percent annual chance elevations). Peak storm-tide elevations, selected annual exceedance probability quantiles, and computed recurrence intervals (and annual exceedance probabilities) are presented in tables 3, 4, and 5 for USGS tide gages, USGS temporary storm-tide sensors, and high-water-mark sites, respectively.

The USGS investigated the spatial variation of peak storm-tide elevations and computed recurrence intervals (and exceedance probabilities) for areas along the New Jersey coast 
associated with Hurricane Sandy. Peak storm-tide elevations recorded at USGS tide gages are shown in figure 4, peak storm-tide elevations recorded at storm-tide sensors are showing in figure 6, and peak high-water-mark elevations at HWM sites are shown in figure 9 to illustrate the variation in peak storm-tide elevations along the New Jersey coast. The spatial distribution of the computed recurrence intervals (and exceedance probabilities) for peak storm-tide elevations associated with Hurricane Sandy at tide gage and storm sensor locations are presented in figure 15. The same comparison for HWM sites is presented in figure 16. Flood-frequency elevations used in this analysis were taken from the Preliminary Coastal Flood Insurance Studies results released between April 2014 and January 2015 (Federal Emergency Management Agency, 2013b). Details about how the data were processed for this analysis are provided in the following section titled "Geospatial Information Systems Data Processing and Methods."

The computations of water-surface elevations associated with selected probabilities for the coastal flood insurance studies along the New Jersey coast and New York City were performed by FEMA Region II and its contractors. The USGS performed the comparison analysis of peak storm-tide elevations associated with Hurricane Sandy to the computed elevations for selected flood frequencies in the preliminary flood insurance study for the New Jersey Coast and New York City.

\section{Geographic Information System Data Processing and Methods}

Geographic information system (GIS) data layers of stillwater elevations for the computed flood frequencies were provided to the USGS by FEMA and RAMPP. FEMA provided StillWater Elevation (SWEL) surface values from the ongoing New Jersey to New York City Coastal Flood Study, by county (Federal Emergency Management Agency, 2013b). The statistical elevation data for each flood frequency interval were merged into one continuous layer, and elevations were extracted for each USGS tide gage, storm-tide sensor, and HWM site and used to estimate a recurrence interval. FEMA special flood hazard areas are identified as letter and numbered special hazard zones in the national flood insurance program guidelines. FEMA also provided a flood zone coverage that was used to define the extent of each special hazard zone (AE or VE zones). As expected, most tide gages, storm-tide sensors, and HWM sites were in AE or VE special hazard zones. However, some sites were in FEMA designated shaded or unshaded $\mathrm{X}$ zones, indicating that the sites were outside FEMA special hazard zones (Federal Emergency Management Agency, 2013c). In this case, stillwater elevation values were extracted from the underlying model data, which extends beyond the special hazard zone boundary, for each flood interval and used to estimate a recurrence interval, but a BFE was not assigned.

\section{Comparison of Historic Exceedance Probabilities for Atlantic City}

Although Hurricane Sandy was an extremely devastating storm along the New Jersey and New York coastlines, it is useful to look back at the history of major coastal storms that caused damage to the coasts of New Jersey and New York in order to gain a better perspective. In addition to looking back and comparing peak storm-tide elevations from major historic storms to Hurricane Sandy peak storm-tide elevations, a comparison of historic storms to the current preliminary probability analysis provides an estimate of the likelihood of annual occurrence of those historic storms. In a USGS Hydrologic Atlas (HA-65), Thomas and Edelen (1965) documented the tidal flooding in Atlantic City, N.J., and vicinity during the March 1962 coastal storm. For the analysis, Thomas and Edelen (1965) used peak storm-tide elevations at two tide gages - Atlantic Ocean at Atlantic City (1912-60) and Beach Thorofare near McKinley Ave. at Atlantic City (1950-60) - and historical data from two tide gages on Absecon Island to compute a somewhat traditional frequency analysis. During the analysis, a gradual variation in annual mean sea level was identified and adjustments were made to the records prior to computation of the frequency analysis for these stations.

Elevations shown in the atlas were referenced to NGVD 29 but were adjusted to NAVD 88 for direct comparison using VERTCON (National Oceanic and Atmospheric Administration, 1999). Thomas and Edelen (1965) computed the high-tide elevations with a 50-year recurrence interval to be $7.7 \mathrm{ft}$ and $8.4 \mathrm{ft}$, NGVD 29, at the Atlantic City and Beach Thorofare tide gages, respectively. A conversion factor of $-1.32 \mathrm{ft}$ was used to adjust these elevations to NAVD 88 using VERTCON and resulting in 50-year recurrence interval elevations of about $6.4 \mathrm{ft}$ and $7.1 \mathrm{ft}$, respectively.

The current preliminary coastal modeling results indicate 50-year recurrence interval tide elevations of $7.96 \mathrm{ft}$ and $7.92 \mathrm{ft}$ at the Atlantic City and Beach Thorofare tide gages, respectively. Adjusting the documented March 1962 storm peak storm-tide elevations of $7.2 \mathrm{ft}$ and $8.3 \mathrm{ft}$ (NGVD 29) at the Atlantic City and Beach Thorofare tide gages using the same factor stated above resulted in peak-tide elevations of about $5.9 \mathrm{ft}$ and $7.0 \mathrm{ft}$ (NAVD 88). Thomas and Edelen (1962) determined that the March 1962 storm peak stormtide elevation at the Atlantic City tide gage had a recurrence interval of about 30 years, and the Beach Thorofare tide gage had a recurrence interval of almost 50 years. Using the current analysis, the same documented peak storm-tide elevations would have estimated recurrence intervals of less than 10 years and 30 years, respectively. For comparison the current USGS tide gage and tidal crest-stage gage at Atlantic City on Inside Thorofare and Beach Thorofare, recorded peak storm-tide elevations from Hurricane Sandy of $7.60 \mathrm{ft}$ and $7.68 \mathrm{ft}$, respectively, both with an estimated recurrence 


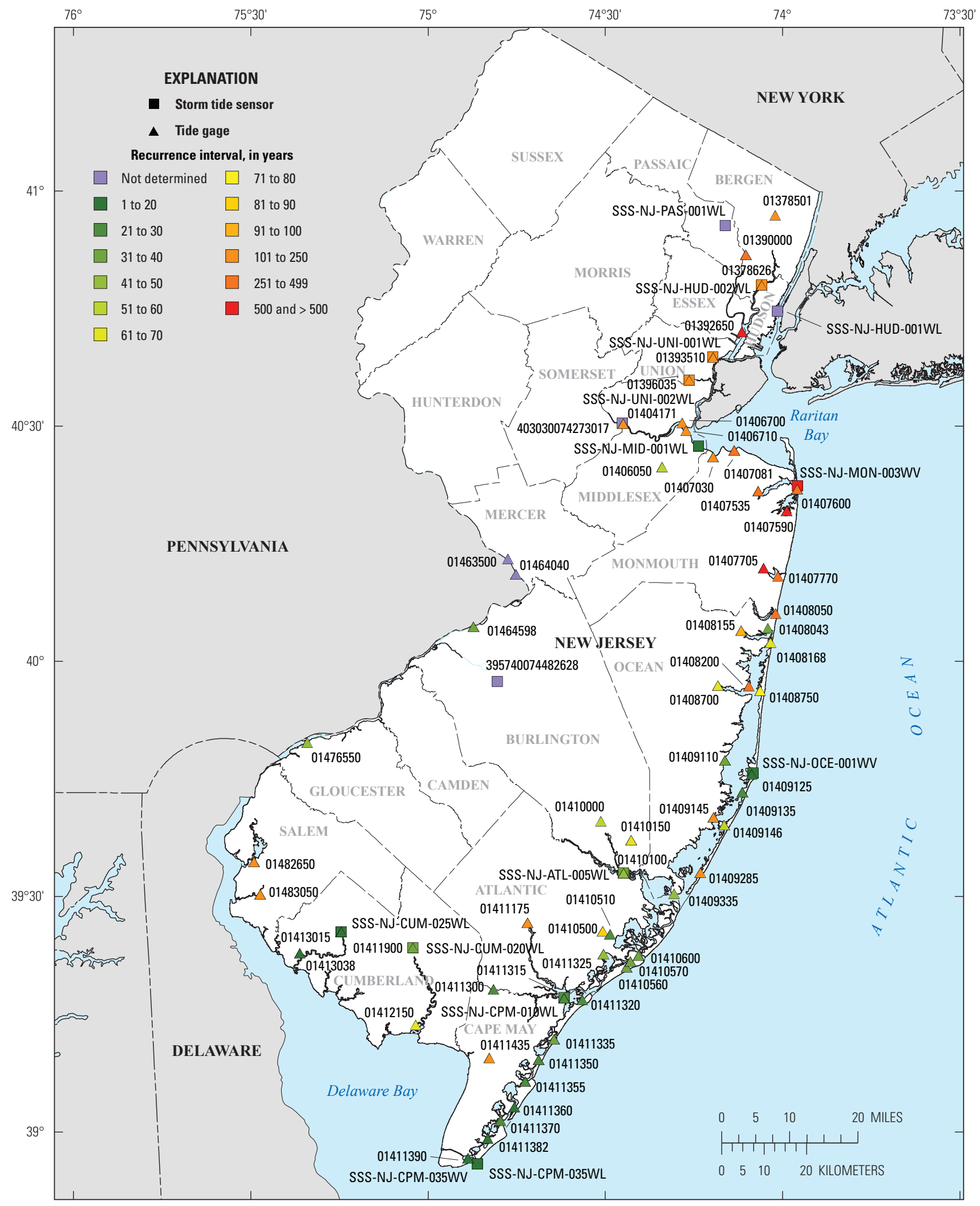

Base from the U.S. Geological Survey, NAD 1983

Universal Transverse Mercator, zone 18N projection

Figure 15. Peak storm-tide elevation recurrence intervals for U.S. Geological Survey tide gages and storm-tide sensor sites along the coast of New Jersey for Hurricane Sandy, October 29-30, 2012. (>, greater than) 


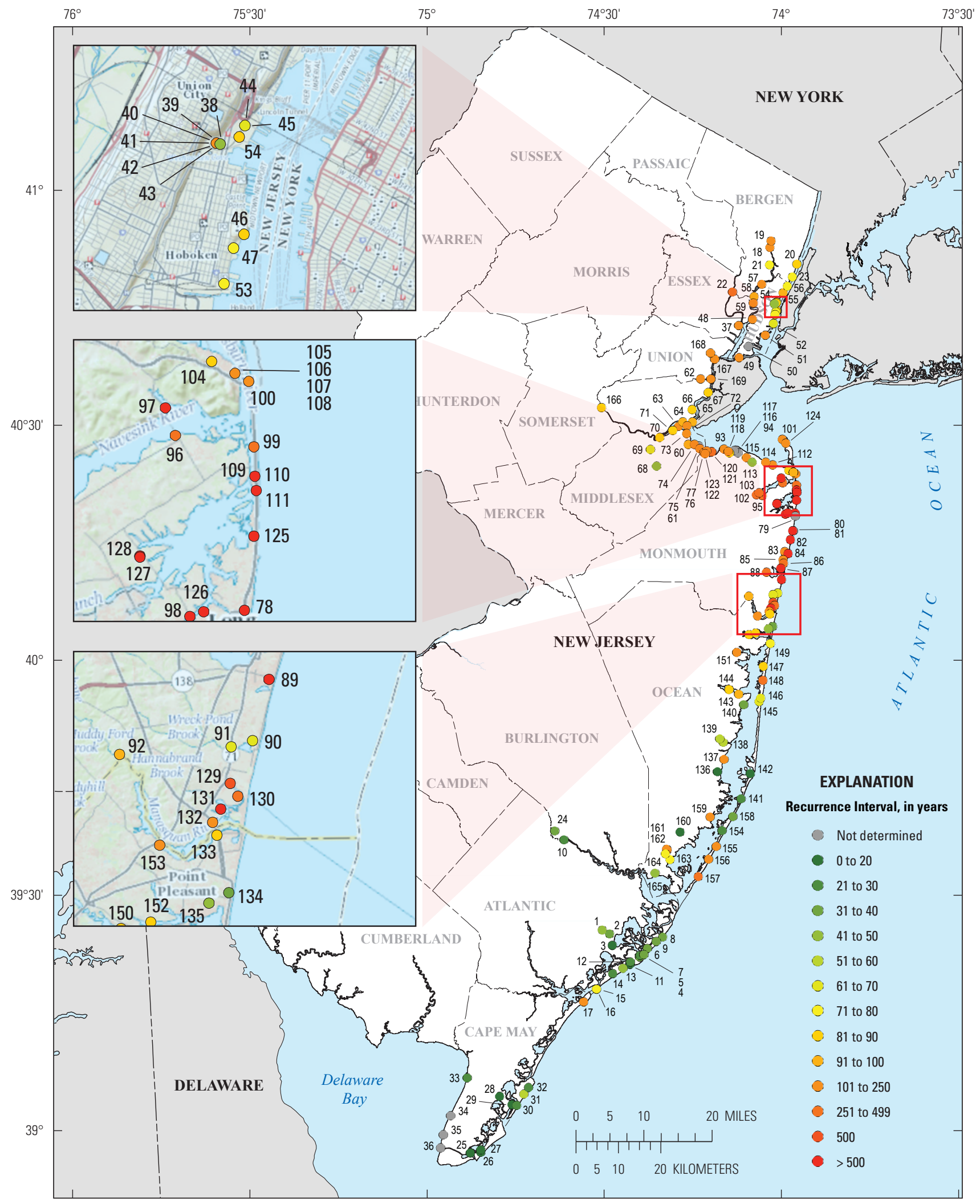

Base from the U.S. Geological Survey, NAD 1983

Universal Transverse Mercator, zone $18 \mathrm{~N}$ projection

Figure 16. Peak storm-tide elevation recurrence intervals for U.S. Geological Survey high-water-mark sites along the coast of New Jersey for Hurricane Sandy, October 29-30, 2012. (>, greater than) 
interval of about 40 years using the preliminary 2013 FEMA FIS for the coast of New Jersey and New York City (table 3). Figure $17 \mathrm{~A}$ is modified from the original Atlantic City inundation map by Thomas and Edelen (1965) to show the extent of flooding from Hurricane Sandy in October 2012 in addition to the inundations from the storms of 1960 and 1962 . Figure $17 B$ is modified from the original Thomas and Edelen (1965) to show HWM elevations from Hurricane Sandy in Atlantic City,
N.J., in October 2012 (green highlight) and the 1960 and 1962 HWM elevations (orange highlight) for comparison of peak storm-tide elevations from these storms. All elevations have been converted to NAVD 88 for direct comparison.

Note that FEMA computes annual exceedance flood elevations using different methods than were applied after the 1962 hurricane hit the coast of New Jersey.

$A$

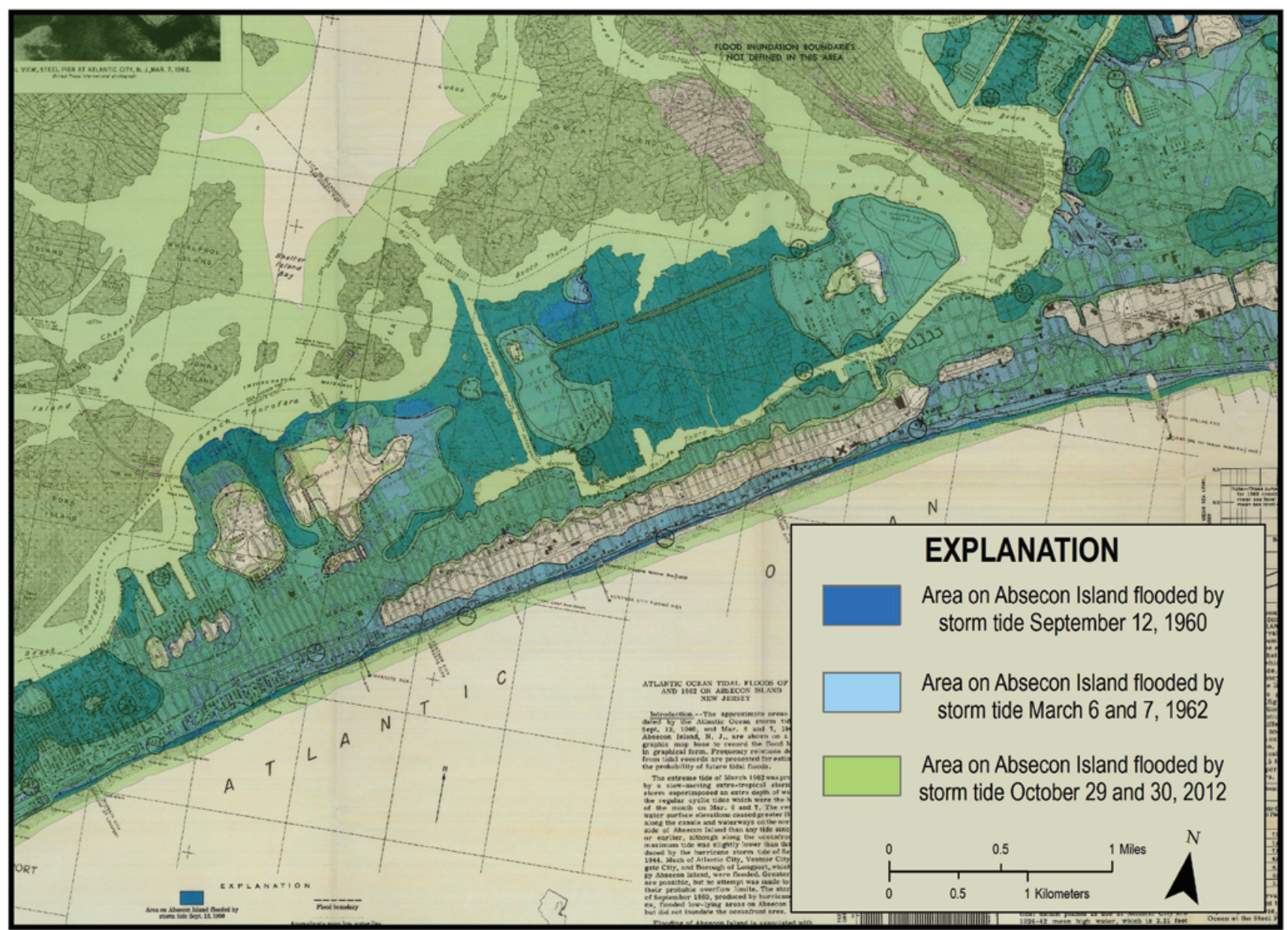

Figure 17. A, Estimated areas of inundation during the storms of 1960 and 1962, and Hurricane Sandy, October 29-30, 2012, Absecon Island, NJ, and $B$, high-water marks from the three storms in Atlantic City, New Jersey. (Modified from Thomas and Edelen, 1965.) 
$B$

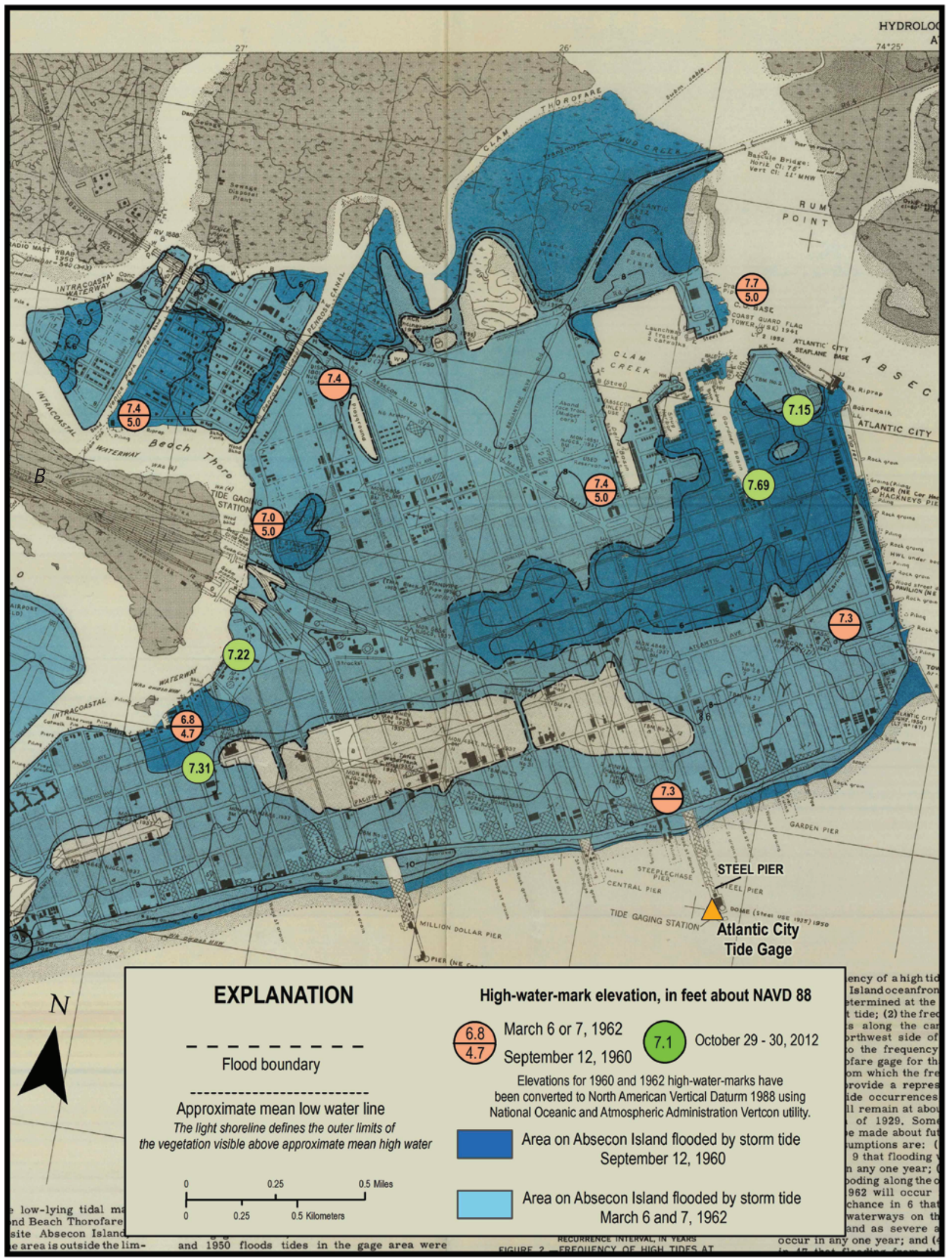

Figure 17. A, Estimated areas of inundation during the storms of 1960 and 1962, and Hurricane Sandy, October 29-30, 2012, Absecon Island, NJ, and B, high-water marks from the three storms in Atlantic City, New Jersey. (Modified from Thomas and Edelen, 1965.) Continued 


\section{Storm-Surge Analysis}

\section{Storm-Surge Magnitude and Timing Associated with Hurricane Sandy}

Many times the terms "peak storm tide" and "storm surge" are mistakenly used interchangeably. Storm surge is defined for this report as the difference between the predicted astronomical tide elevation and the observed tide elevation. Peak storm-tide elevation is defined for this report as the maximum tidal watersurface elevation at a given location referenced to a vertical datum. The USGS estimated the astronomical tide elevations referenced to NAVD 88 at selected USGS tide gages in order to analyze the timing of peak storm surge associated with Hurricane Sandy.

Coastal flooding for many communities along the eastern coast of New Jersey was worse because the peak storm tide associated with Hurricane Sandy was in phase with the astronomical high tide (fig. 18A-H). Communities at the southern end of New Jersey in and around Cape May County were more fortunate than other communities because they were on the left side of the hurricane circulation (counterclockwise), and the peak storm tide was slightly out of phase with the astronomical high tide. As the storm approached landfall near Atlantic City, N.J., the communities north along the coast near Long Branch, Sea Bright, Sandy Hook, and Raritan Bay unfortunately were aligned with the right-front quadrant of the storm, and the timing of the storm was more in phase with astronomical high tide. The better alignment with the peak winds driving storm surge directly at the coast became more precise as the storm changed directions and moved east-northeast prior to landfall. The combination of these two factors produced record-setting flooding at many locations along the coast of New Jersey.

The magnitude and timing of the Hurricane Sandy storm tide with the astronomical tide produced an initial high tide of almost $6 \mathrm{ft}$ (NAVD 88) at the Manasquan River at Point Pleasant tide gage on October 29, 2012, and a much higher high tide of about $9.5 \mathrm{ft}$ later that night (fig. 18C). The first high tide on October 29 was predicted to be the higher high tide, but the timing of the storm resulted in a much greater high tide later that evening. The peak storm surge at the Manasquan River at Point Pleasant tide gage was computed to be more than $8 \mathrm{ft}$ for October 29,2012, but it is important to note that a sustained surge of around $5 \mathrm{ft}$ was maintained from about 9 a.m. eastern daylight time (EDT) on October 29 until almost midnight.

The sustained storm surge and extreme peak storm tide produced enough energy to erode dunes and create a breach in the barrier peninsula, customarily referred to as a barrier island, at Mantoloking. Turbidity data from the USGS water-quality streamgage at Barnegat Bay at Route 528 at Mantoloking, N.J., was used in conjunction with tide elevation data from nearby USGS tide gages to estimate the timing of the breach. Although the ocean side of the barrier island at Mantoloking was being eroded by waves for several hours prior to the actual breach, it was estimated that the actual breach occurred between about 1900 and 2100 hours EDT (7:00 and 9:00 p.m.) on October 29, 2012. The peak storm tide at the Manasquan River at Point Pleasant tide gage and the Barnegat Bay at Mantloking tide gage occurred at 20:36 hours (8:36 p.m. EDT) on October 29, 2012, and 02:16 hours (2:16 a.m. EDT) on October 30, 2012, respectively. Similar sustained storm surge was noted at the Shrewsbury River at Sea Bright and the Raritan Bay at Keansburg, N.J., tide gages on October 29, 2012 (fig. 18A-H).

The USGS was able to collect light detection and ranging (lidar) data before the storm made landfall in Barnegat Bay and in the area near Mantoloking, and again shortly after the storm breached the barrier island. The lidar surveys were conducted by the USGS Coastal and Marine Geology Program using the second generation Experimental Advanced Airborne Research Lidar-B (EAARL-B) topobathymetric lidar instrument (Wayne Wright, USGS, written comm., 2014). The elevation data and calculated elevation change data are presented in figure 19 for the area near Mantoloking, N.J. The lidar elevation data presented in figure 19, collected before and after the storm, show a general decrease in elevation by as much as $22.3 \mathrm{ft}(-6.8 \mathrm{~m})$ along the coastal side of the barrier island near Mantoloking. Alternatively, elevations along many streets and on the bay side of Mantoloking, adjacent to the breach, showed an increase of $0.65 \mathrm{ft}$ ( 0.2 meters) or more. Elevations of the land surface directly at the site of the breach were lower after the storm; the change in elevation ranged from 0.6 to $22.3 \mathrm{ft}$ ( -0.2 to -6.8 meters). A second area, slightly north of the site of the breach, had a decrease in elevation of about $22.3 \mathrm{ft}$ (6.8 meters) or more. The decrease in elevation at the second location extended from the ocean side of the island to Route 35 (Ocean Avenue, not shown in a figure).

Another important factor in the analysis of storm surge is the topography of the affected areas. The USGS flagged and surveyed HWMs that showed inundation depths of a few feet or greater along the northern and southern coast of New Jersey; however, the elevation of the peak storm tide was much higher along the northern coast of New Jersey. Peak storm-tide elevations of greater than 8 to $10 \mathrm{ft}$ with a calculated peakstorm surge of more than $6 \mathrm{ft}$ were observed along parts of the northern coast of New Jersey. Similar peak storm-tide elevations and peak storm surges in southern New Jersey would have resulted in a much greater inundation and potential damage. After the storm, FEMA developed a hindcast prediction of the areas inundated by Hurricane Sandy along the coast of New Jersey and New York using the best available model data for storm track and intensity. These layers are discussed in more detail in the next section "Extent of Flood Inundation." Peak storm-tide elevations determined from the final FEMA inundation layer of the hindcast modeling, dated February 2013, and ground elevations from the USGS National Elevation Dataset at HWM sites within 0.5 mile of the coastline of New Jersey are shown in figure 20. This figure is presented to show the relation between peak storm-tide elevations, estimated depth of inundation, and spatial variability along the coast of New Jersey. 
A

01407081 Raritan Bay at Keansburg, NJ

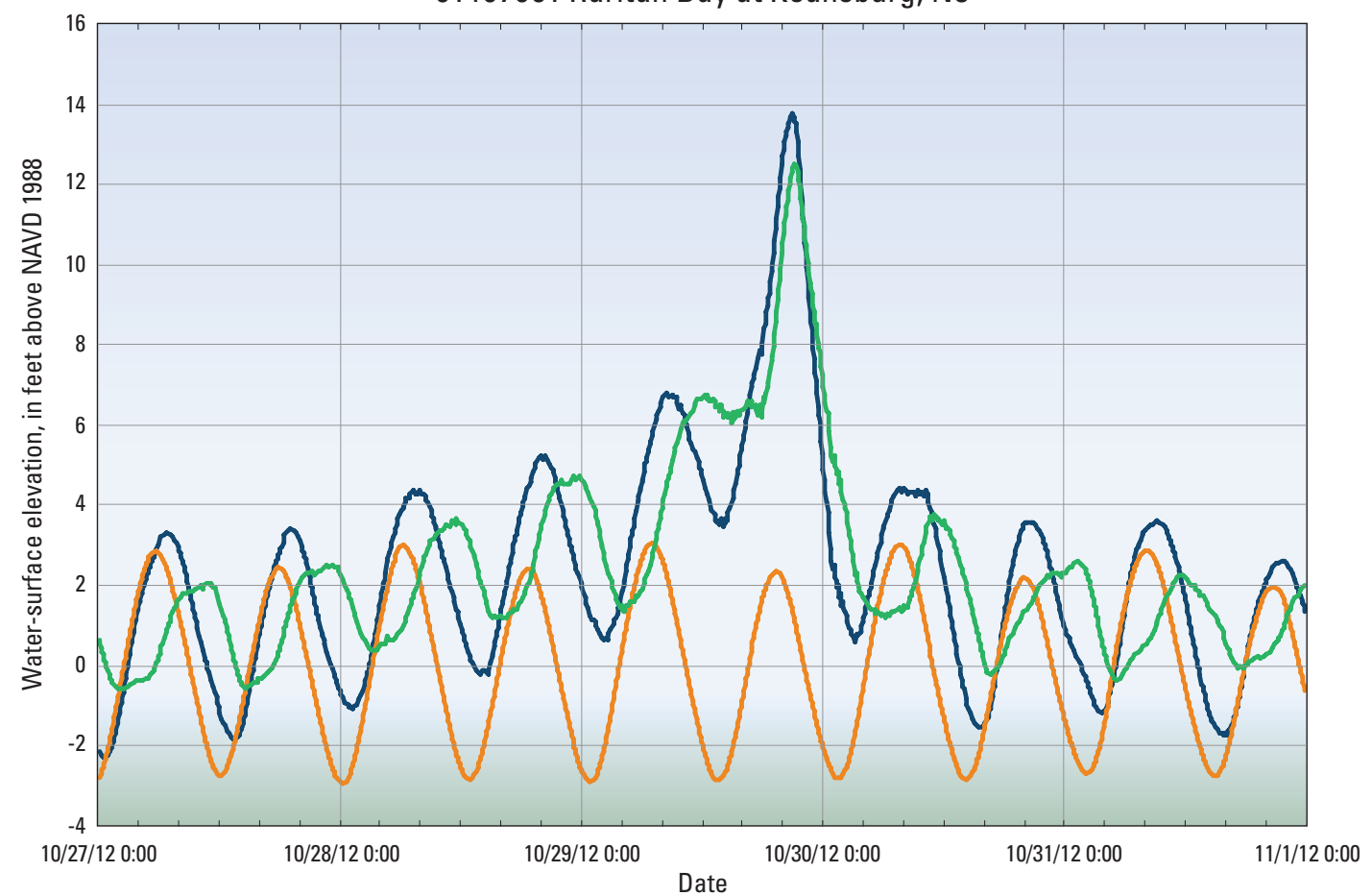

$B$

01407600 Shrewsbury River at Sea Bright, NJ

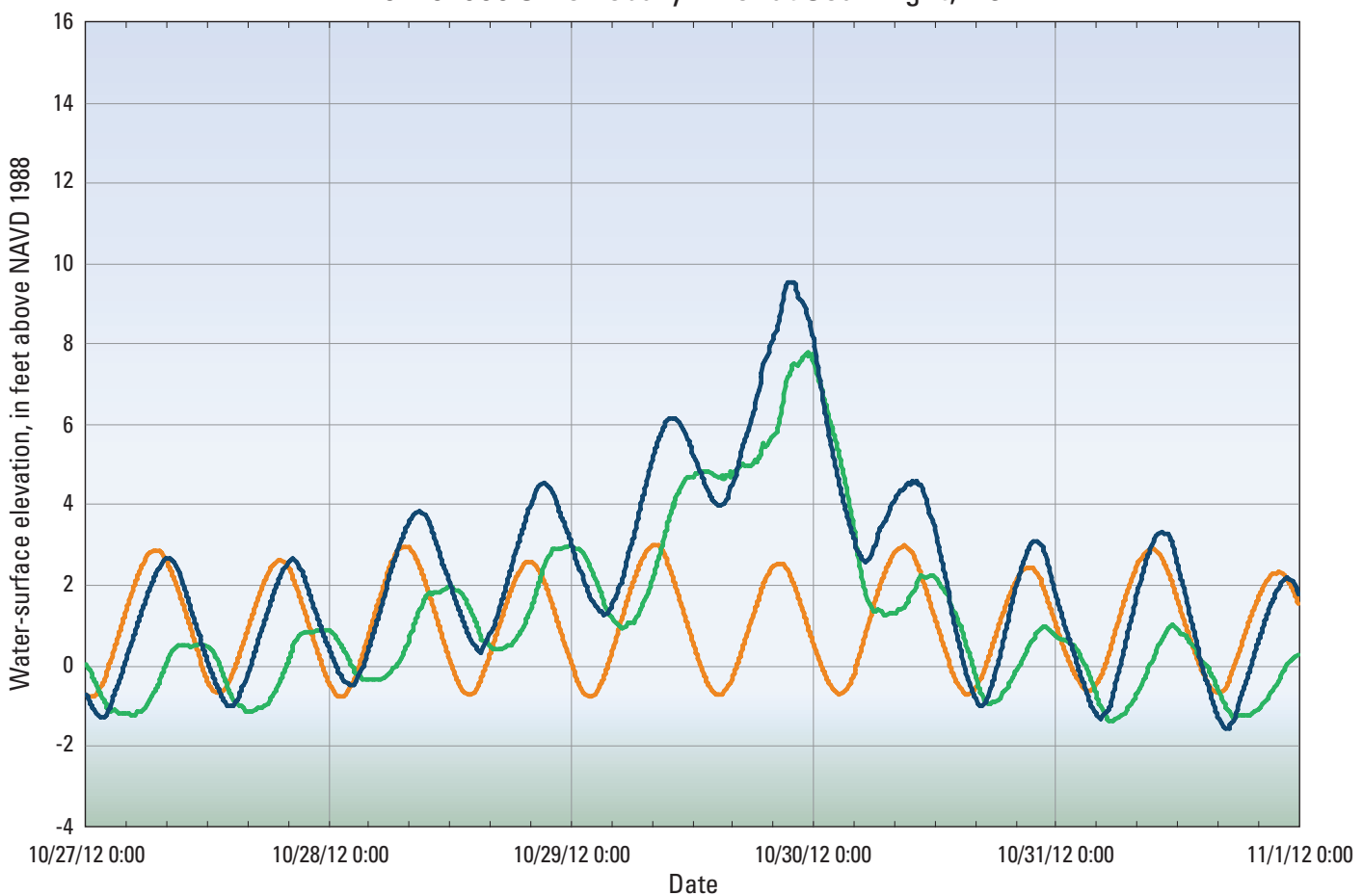

EXPLANATION

Figure 18. Predicted and recorded storm-tide elevations, and computed storm surge during October 27-November 1, 2012, at selected tide gages along the coast of New Jersey: $A$, Raritan Bay, B, Shrewsbury River, $C$, Manasquan River, $D$, Barnegat Bay, $E$, Barnegat Inlet, F, Little Egg Inlet, G, Absecon Creek, and H, Cape May Harbor. 
C

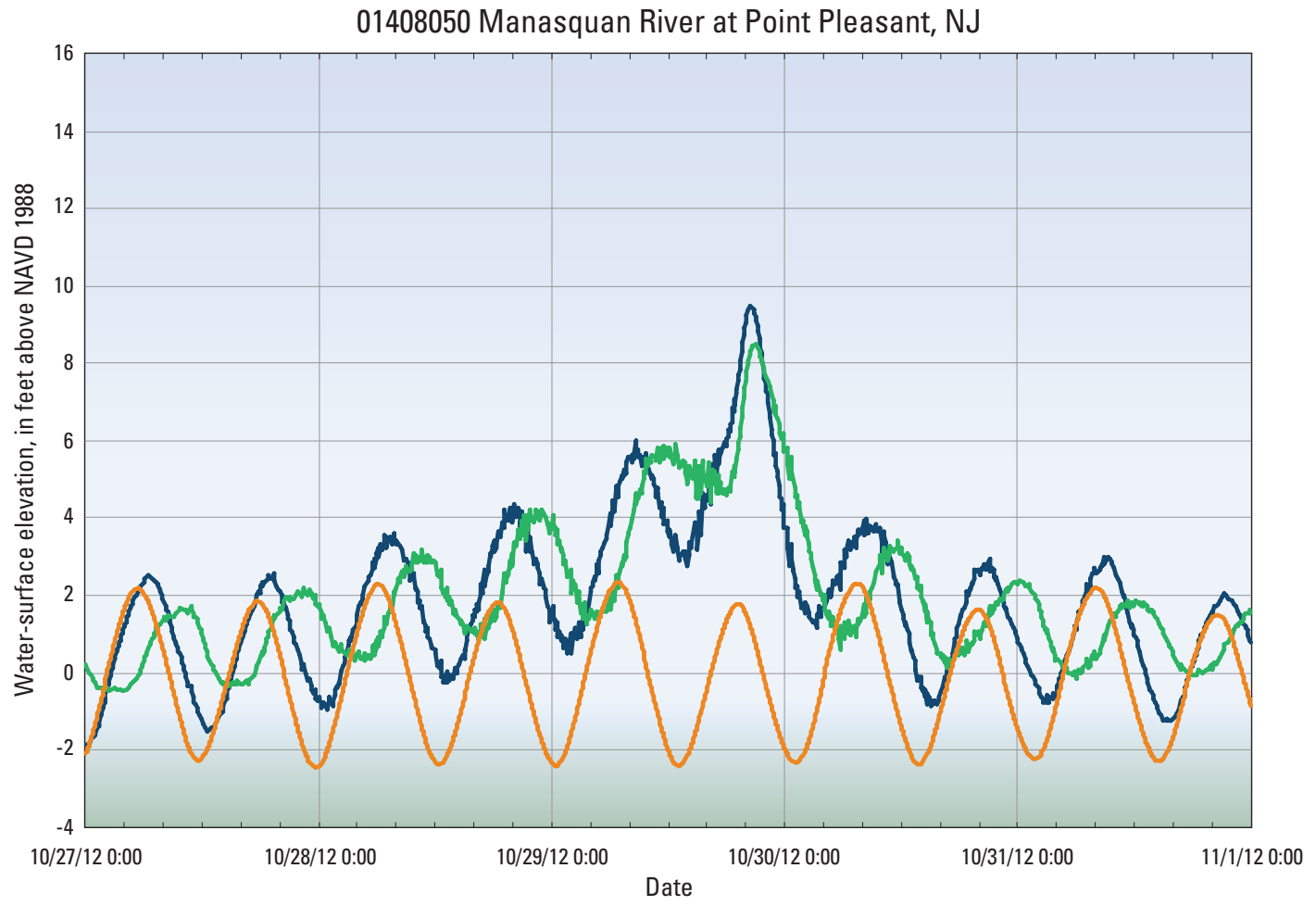

$D$

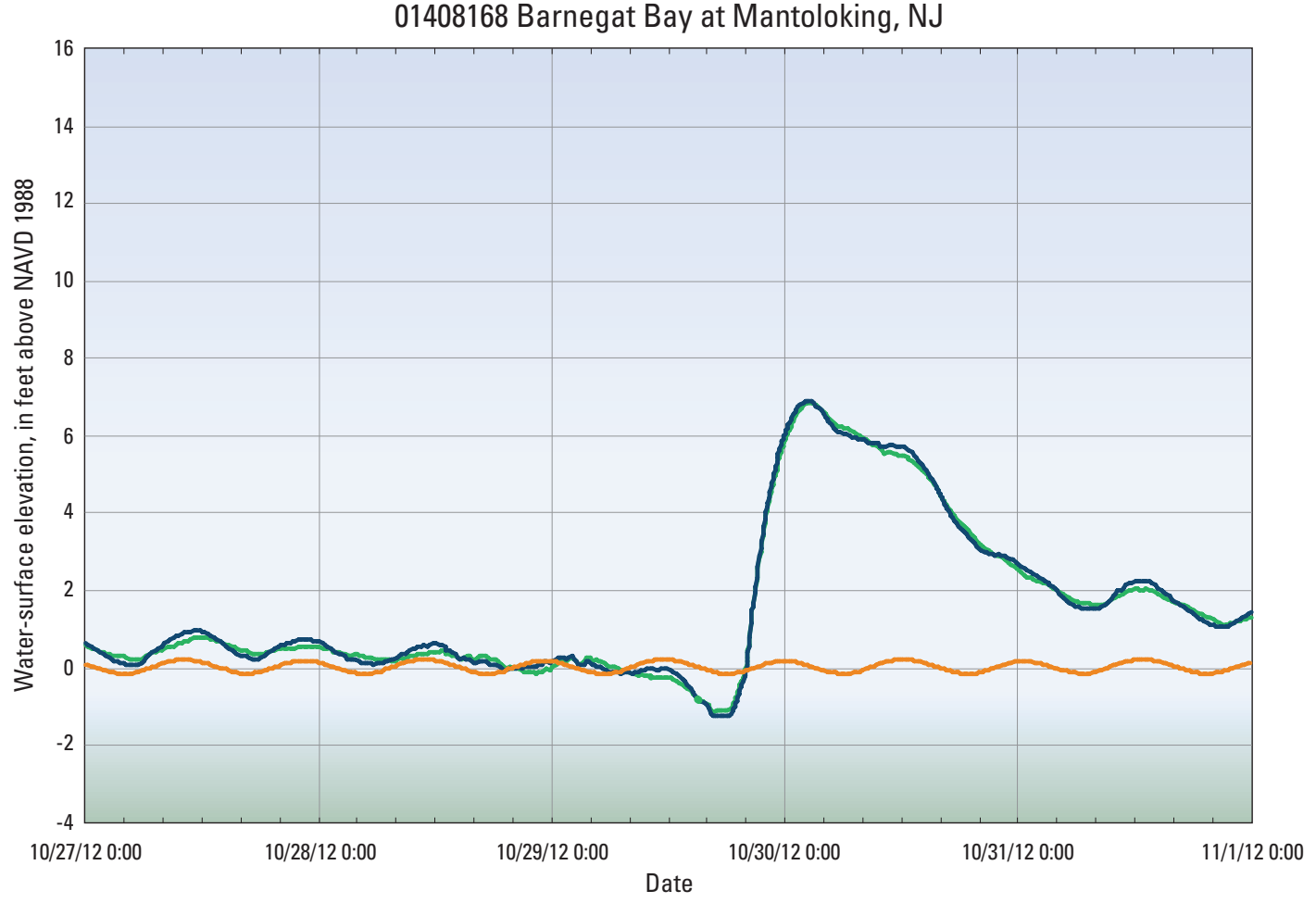

EXPLANATION

— Observed - Estimated predicted _ Storm surge (observed minus predicted)

Figure 18. Predicted and recorded storm-tide elevations, and computed storm surge during October 27-November 1, 2012, at selected tide gages along the coast of New Jersey: $A$, Raritan Bay, B, Shrewsbury River, $C$, Manasquan River, $D$, Barnegat Bay, E, Barnegat Inlet, F, Little Egg Inlet, G, Absecon Creek, and H, Cape May Harbor.-Continued 
$E$

01409125 Barnegat Inlet at Barnegat Light, NJ
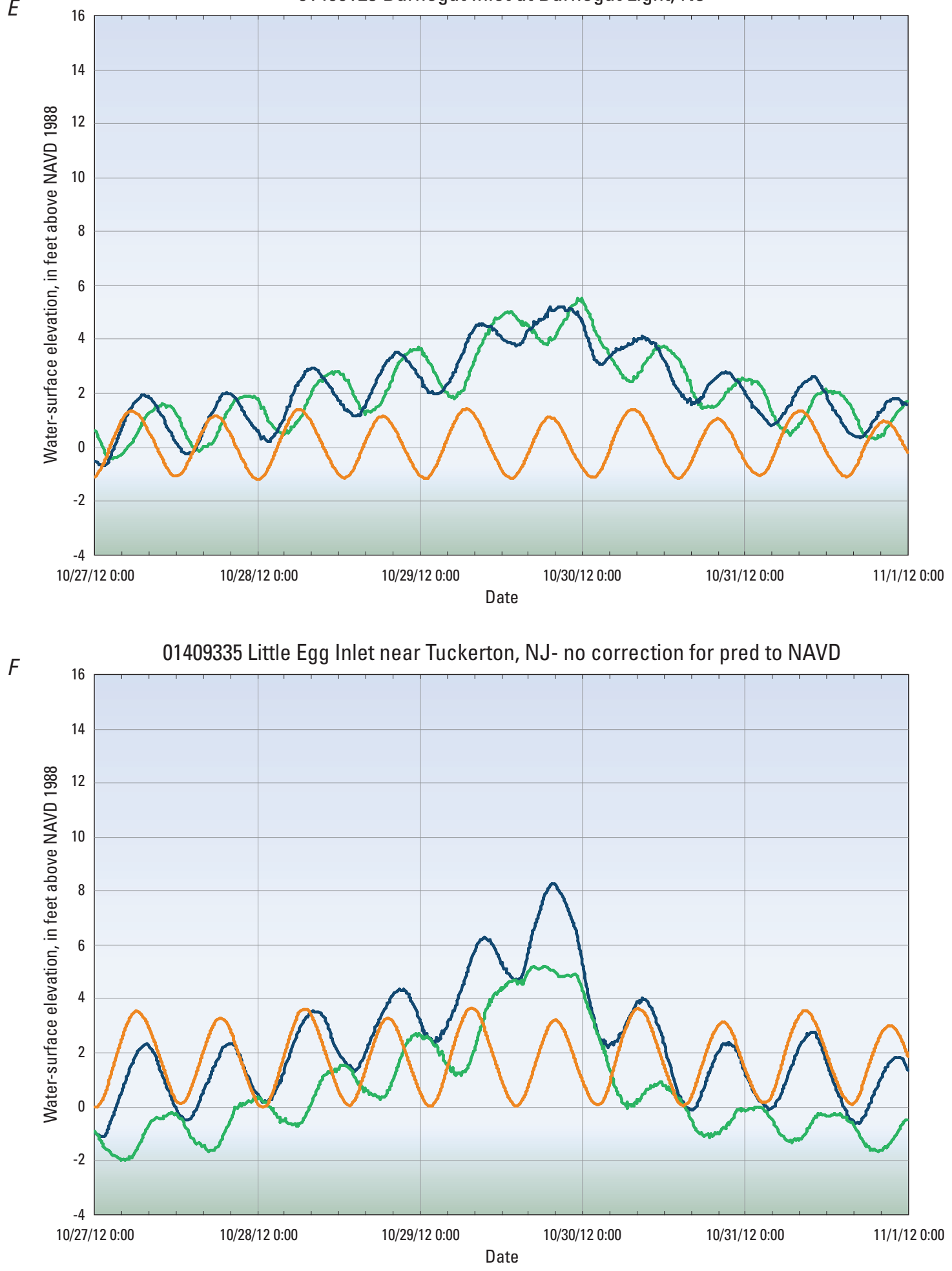

EXPLANATION

— Observed _ Estimated predicted — Storm surge (observed minus predicted)

Figure 18. Predicted and recorded storm-tide elevations, and computed storm surge during October 27-November 1, 2012, at selected tide gages along the coast of New Jersey: $A$, Raritan Bay, B, Shrewsbury River, $C$, Manasquan River, $D$, Barnegat Bay, E, Barnegat Inlet, F, Little Egg Inlet, G, Absecon Creek, and H, Cape May Harbor--Continued 
G
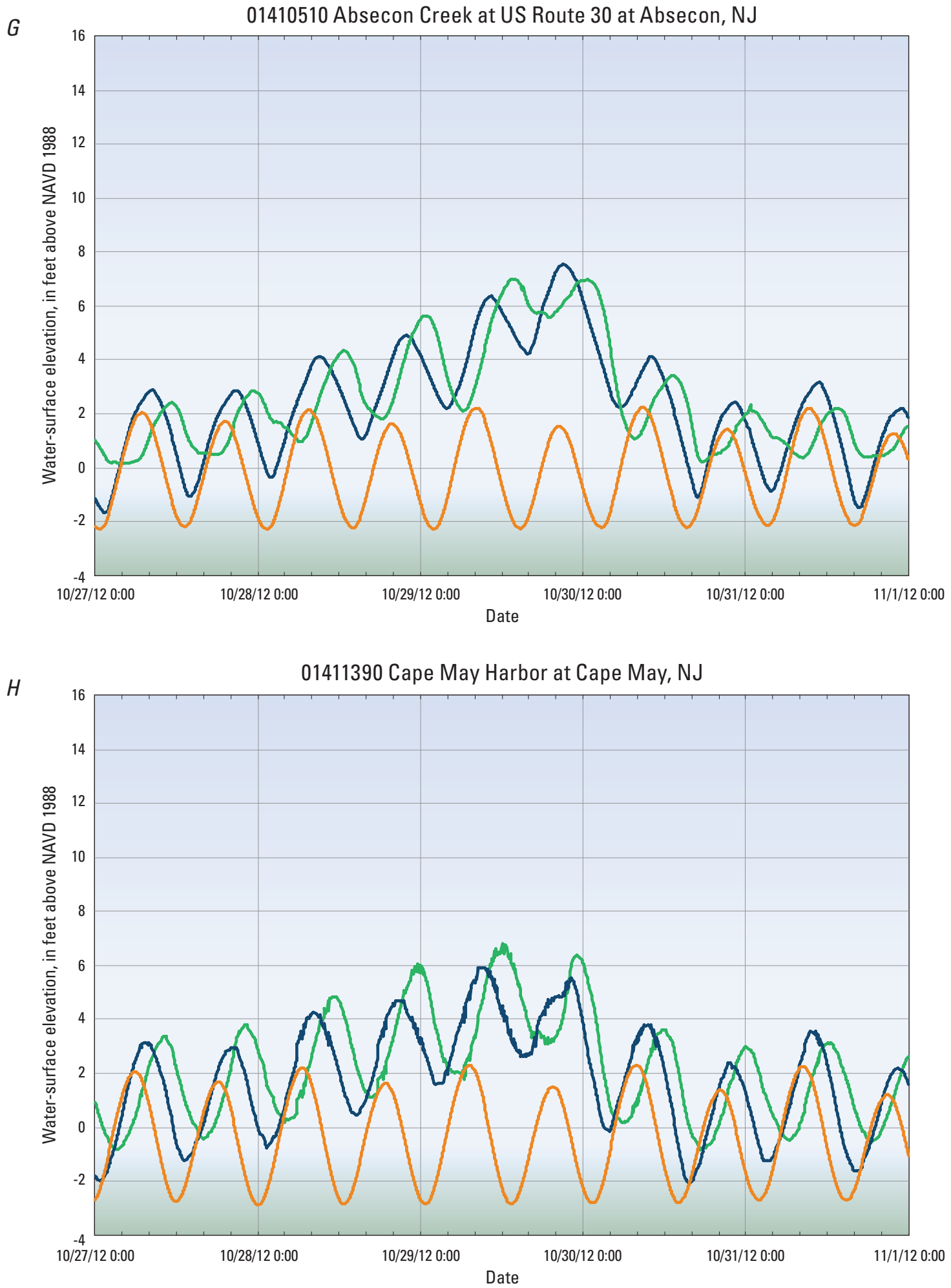

EXPLANATION

— Observed — Estimated predicted $\quad$ Storm surge (observed minus predicted)

Figure 18. Predicted and recorded storm-tide elevations, and computed storm surge during October 27-November 1, 2012, at selected tide gages along the coast of New Jersey: $A$, Raritan Bay, B, Shrewsbury River, $C$, Manasquan River, D, Barnegat Bay, E, Barnegat Inlet, $F$, Little Egg Inlet, G, Absecon Creek, and H, Cape May Harbor.-Continued 


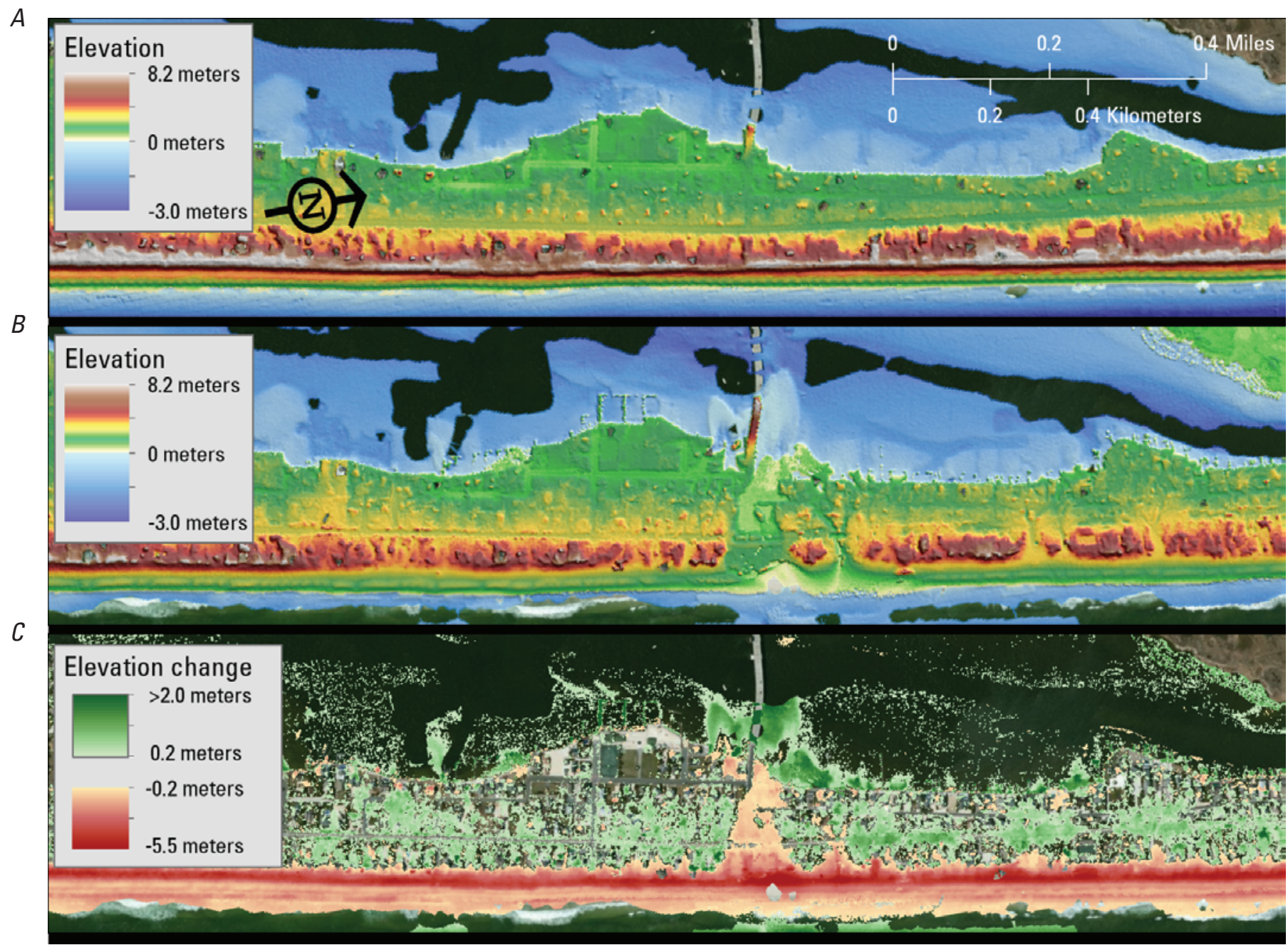

Figure 19. Elevation data for Mantoloking, $N J$, collected $A$, before, $B$, after the storm tide associated with Hurricane Sandy that damaged the New Jersey coastline on October, 29-30, 2012, and $C$, change in elevation from before to after the storm tide. (Lidar surveys were conducted by the U.S. Geological Survey Coastal and Marine Geology Program using the second generation Experimental Advanced Airborne Research Lidar-B (EAARL-B) topobathymetric lidar instrument, >, greater than) 

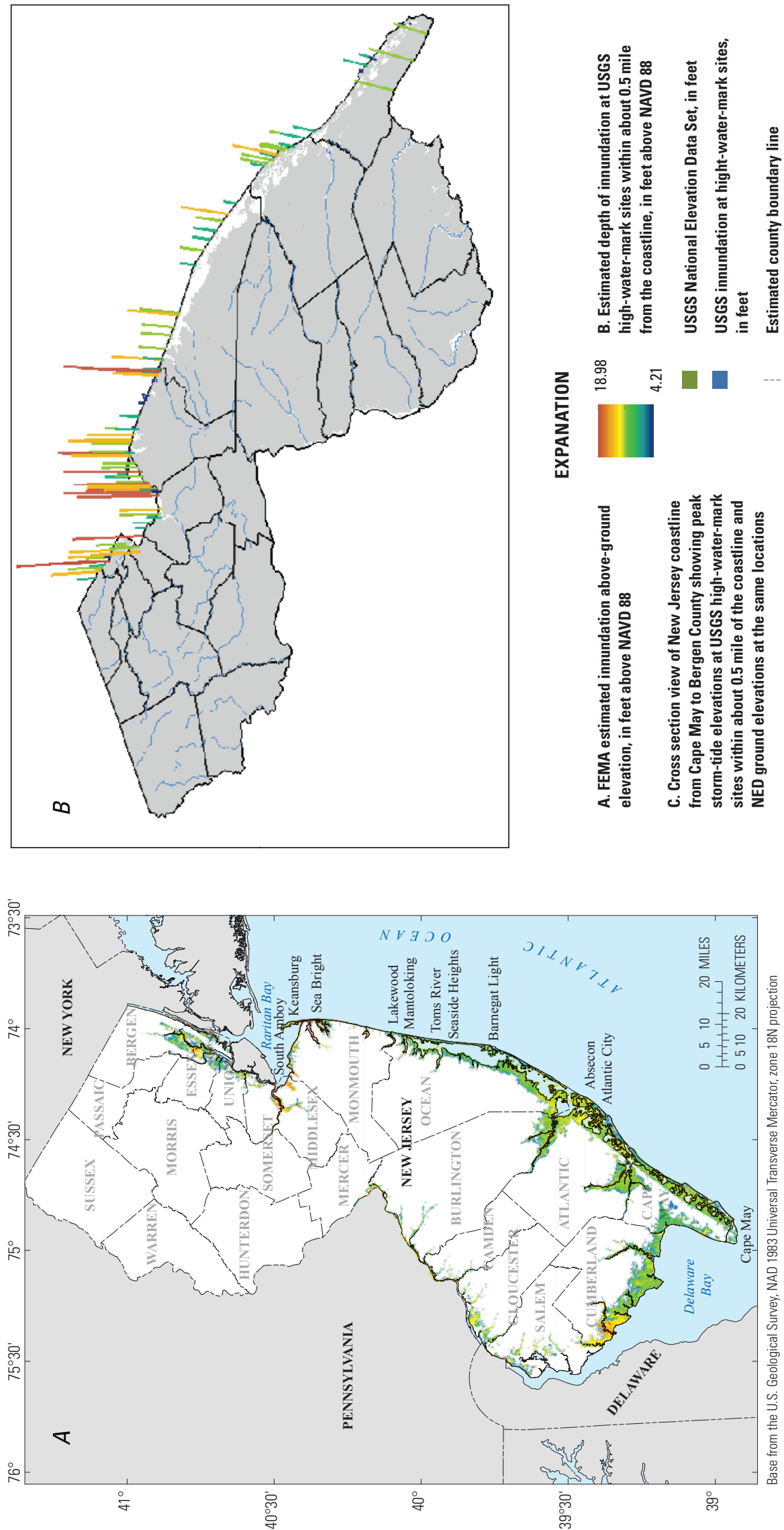

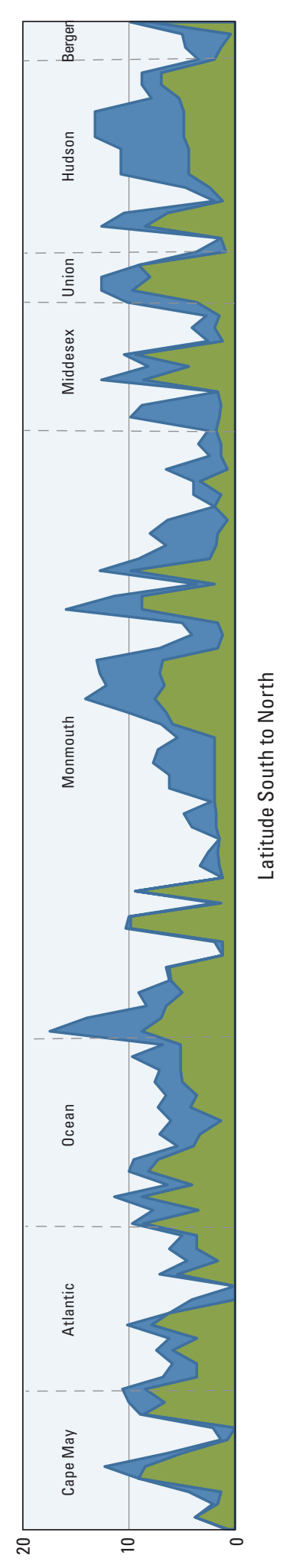

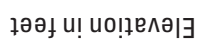

吅

응

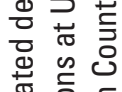

毞 음

ब ذ

๑ व

穴芒

文

䲶离

六苋苋

क त

包施

可 岂

늫 을 을

통 응

는 is

ฟे는

क凶

\丶등 음

之 ब

论

芯

บ 0 는

틈음

든은

ธั

을

중 융 흉

듣흐음

पั

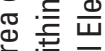

此

엉 일 을

的

离 흔

글 힝 음

范

文古

․ㅡㄹ 응

Ф

宁艺

入े

ปे

可

틈을

증 응

진 웜

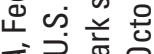

ष

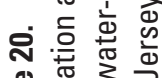

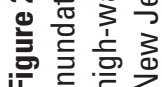




\section{Extent of Flood Inundation}

\section{Comparison of Hindcast Model Predictions with Final USGS Verified Inundations}

FEMA generated several inundation layers using the National Hurricane Center's Sea, Lake, and Overland Surges from Hurricanes (SLOSH) model predictions as Hurricane Sandy was approaching the New Jersey coast (National Hurricane Center, 2013c). After this storm made landfall in New Jersey, FEMA developed a hindcast prediction of the areas inundated by Hurricane Sandy along the coast of New Jersey and New York using the best available data on storm track and intensity.

The USGS deployed field crews immediately after the storm to collect data from the temporary storm sensors that were deployed as the storm was approaching and to collect and survey hundreds of HWMs along the coast to verify the depth and extent of inundation. Subsequent inundation maps were produced by FEMA as data were transmitted to the USGS office from the field. The USGS provided a special Web site that listed peak storm-tide elevations for all sites along the Atlantic coast where data were collected. The Web site was available immediately after the storm hit and was populated with data from the field on a daily basis beginning the day after the storm. The map interface on the special Hurricane Sandy webpage was termed "Sandy Mapper" and was used to provide real-time updates from the field crews and to show the interim inundation layers developed by the FEMA Region IV mapping group.

After all of the USGS HWM data were collected and analyzed, the FEMA mapping group released a final inundation layer on February 14, 2013. The extent and depth of inundation on this final layer were adjusted to agree with the USGS HWM locations and elevations. The digital elevation model used was also changed from the initial 30-meter grid cell size dataset to a finer 10-meter grid cell size dataset. The initial SLOSH inundation estimates, the final February 14 inundation layers, and a layer showing the change from initial to final inundations are presented in figure $21 A-C$.

As an example of the change in flood extent at some locations due to the data collection at HWM sites, the hindcast estimates are shown in figure 22 along with the final February 14, 2012, inundation extent for a selected area near Tuckerton, N.J., and vicinity. The flood extent produced by the hindcast analysis likely is the best available SLOSH model output generated without incorporating field data. The final extent of inundation from the February analysis, generated using USGS HWMs to adjust the depth and extent of inundation on the basis of field collected data, is shown in figure 22 .

FEMA has developed a methodology for estimating potential losses from disasters called HAZUS (HAZards United States). It is a nationally applicable standardized system that includes models for estimating potential losses from earthquakes, floods, and hurricanes (Federal Emergency Management Agency, 2013d). The USGS conducted a level 1 HAZUS analysis on total building stock losses that used the predicted inundation areas from the National Hurricane Center SLOSH model hindcast compared with the interim and final inundations verified using USGS HWMs, filtered storm-tide sensor data, and tide-gage data. The hindcast model was run after the storm on October 31, 2012, using the best available data. The interim inundation data from November 11, 2012, included a mostly complete dataset for the areas affected along the New Jersey coast but only included limited USGS HWM data for the affected New York areas. The final inundation dataset of February 14, 2013, included all USGS field data collected during and after the storm in the affected areas of New Jersey and New York. For this report, the October 31, 2012, November 11, 2012, and February 14, 2013, inundations will be referred to as the "predicted," "interim," and "final" inundations, respectively. The level 1 analysis is a basic analysis that produces estimated losses on the basis of national databases and expert-based analysis parameters included in the HAZUS software. The HAZUS analysis was done using asset values from the HAZUS national database and default loss functions. The analysis was conducted on a census block level, then aggregated at the county level (fig. $23 A-C$ ). The loss data presented include all general building stock losses but do not include contents losses. Differences in the HAZUS loss estimates between the final and predicted analyses are shown in figure $23 D$.

The use of USGS field data to verify the level and extent of inundation from the storm surge associated with Hurricane Sandy resulted in a major change to the estimated losses. The estimates of total building losses using the predicted inundation from the hindcast SLOSH model output showed losses that range from $\$ 2$ million to more than $\$ 4$ billion for some counties in New Jersey (fig 23A). The losses from the interim inundation HAZUS analysis in New Jersey ranged from $\$ 2$ million to more than $\$ 3$ billion for individual counties, but the results also included several northern counties that previously had no losses (fig 23B). The HAZUS estimated losses using the final inundation showed mostly minor changes from the interim inundation with the exception of the counties in northeastern New Jersey, which continued to show increased losses (fig 23C). The total estimated aggregate HAZUS building losses for New Jersey were about $\$ 19$ billion, and the change in HAZUS total building loss estimates for New Jersey from the predicted inundation estimates to the final inundation estimates approached $\$ 8$ billion (fig 23D).

The results for the adjacent New York counties showed a similar change to those for New Jersey counties, except the change in estimated total building losses in New York was a general increase. In New York the total aggregate HAZUS building losses were estimated to be about $\$ 23$ billion. Additional analysis for New York was conducted by Schubert and others (2015). 

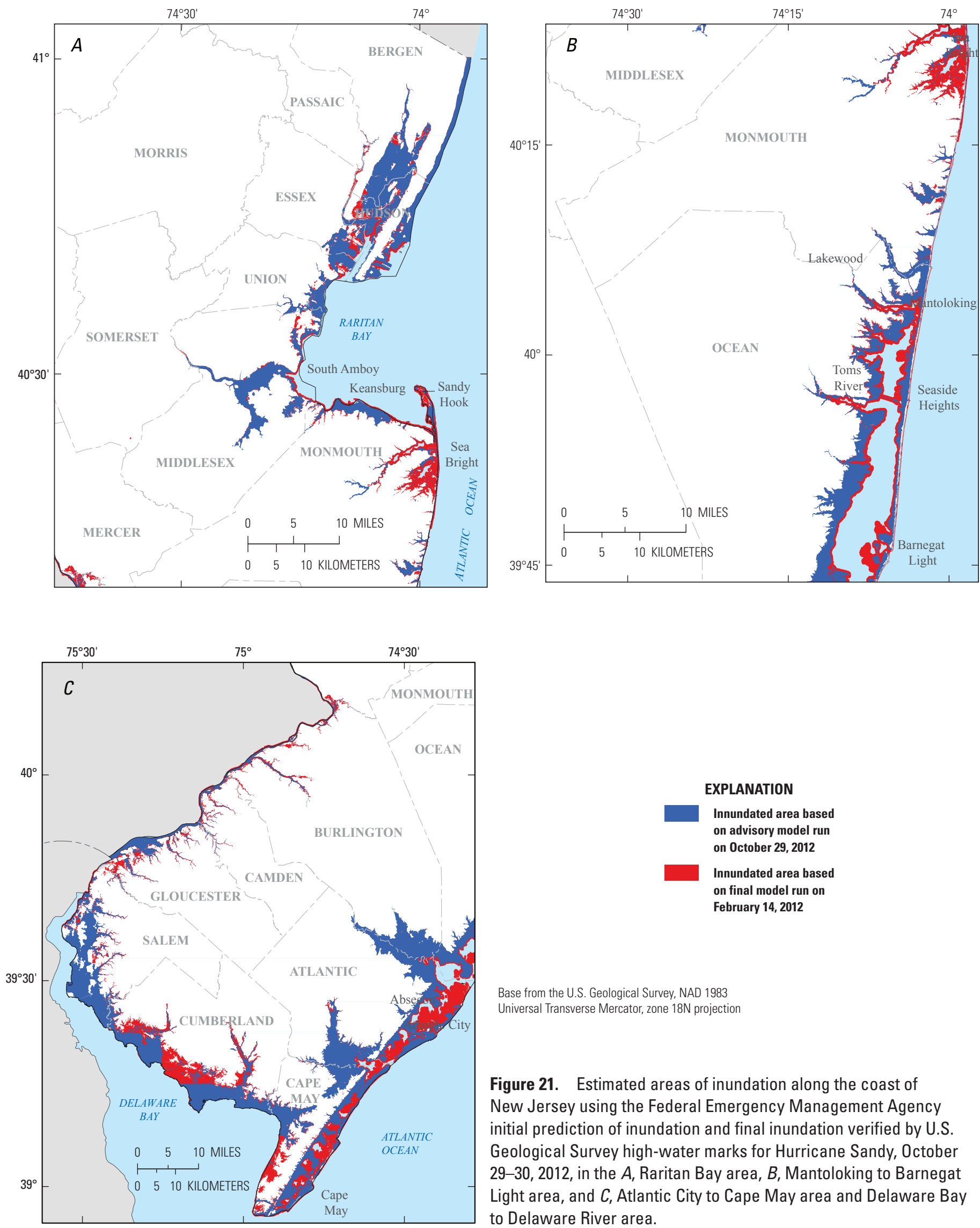

Base from the U.S. Geological Survey, NAD 1983 Universal Transverse Mercator, zone 18N projection

Figure 21. Estimated areas of inundation along the coast of New Jersey using the Federal Emergency Management Agency initial prediction of inundation and final inundation verified by U.S. Geological Survey high-water marks for Hurricane Sandy, October 29-30, 2012, in the $A$, Raritan Bay area, $B$, Mantoloking to Barnegat Light area, and $C$, Atlantic City to Cape May area and Delaware Bay to Delaware River area. 


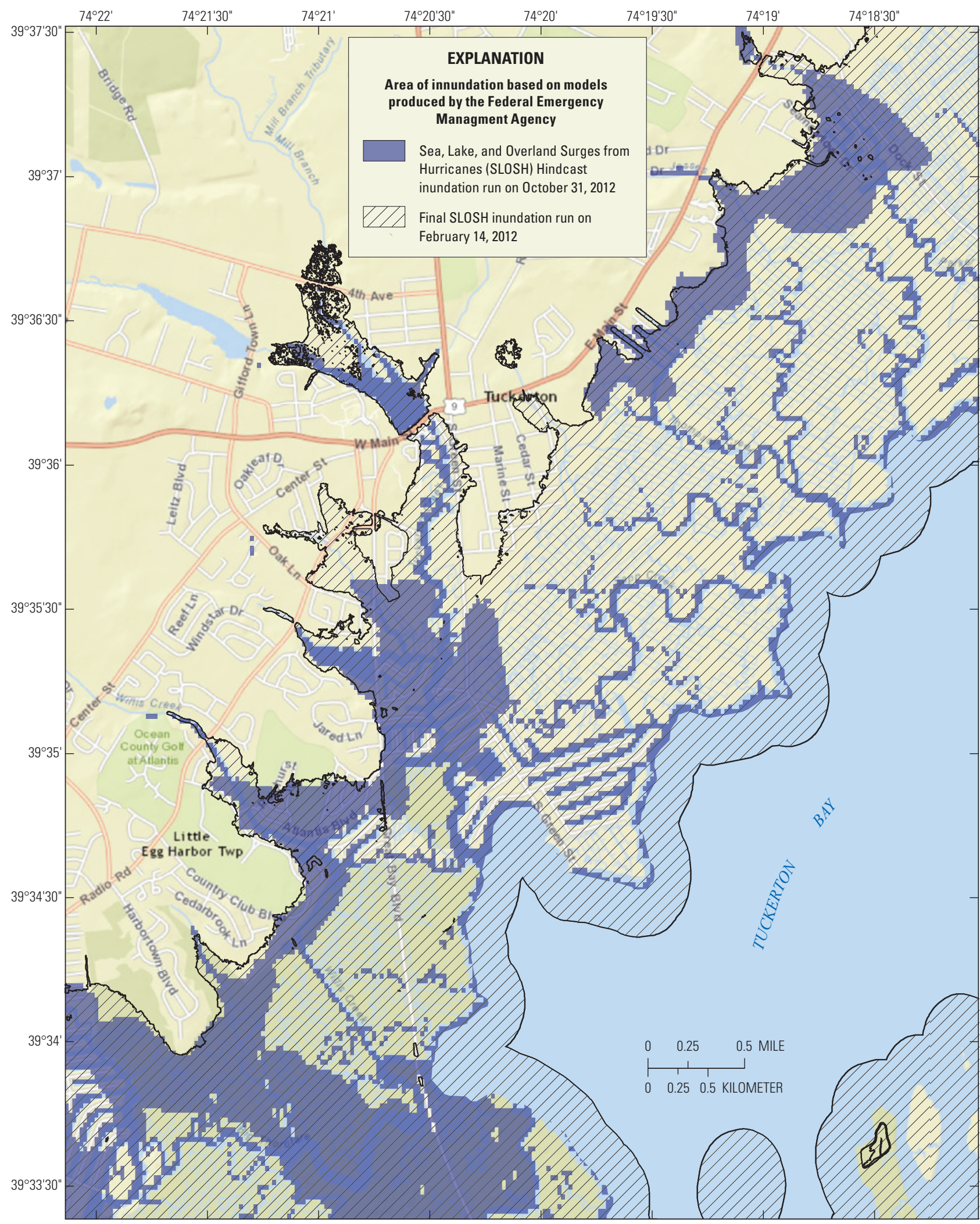

Base from Esri, HERE, DeLorme, USGS, Intermap, increment P Corp., NRCAN,

Esri Japan, METI, Esri China (Hong Kong), Esri (Thailand), MapmyIndia,

(c) OpenStreetMap contributors, and the GIS User Community

Figure 22. Estimated areas of inundation at Tuckerton, New Jersey, and near by vicinity, using the Federal Emergency Management Agency initial October 31, 2012, prediction of inundation and final February 14, 2013, inundation estimates verified by U.S. Geological Survey high-water marks for Hurricane Sandy, October 29-30, 2012. 
$A$

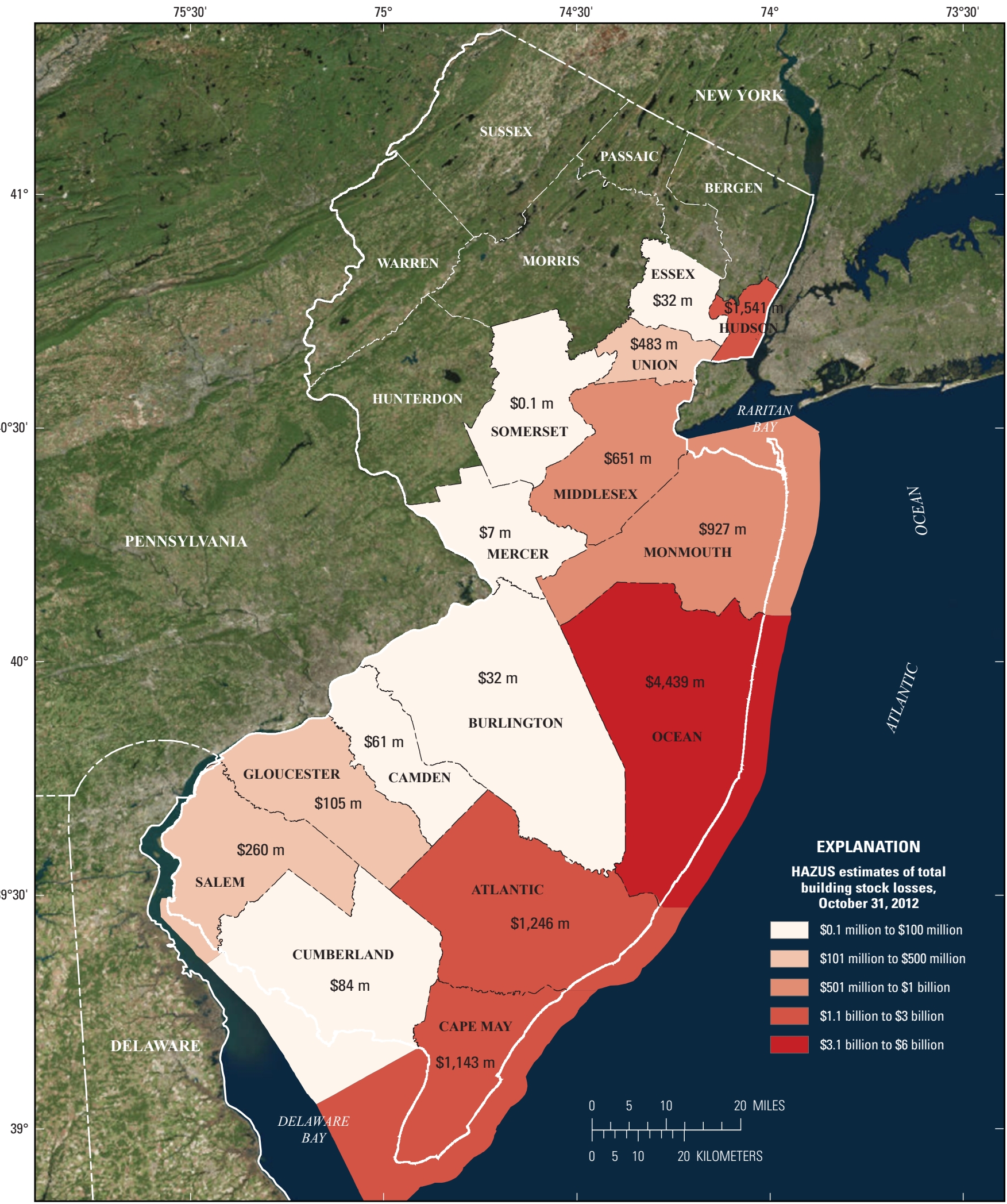

Base from Esri, DigitalGlobe, GeoEye, Earthstar Geographics, CNES/Airbus DS, USDA, USGS, AEX, Getmapping, Aerogrid, IGN, IGP, swisstopo, and the GIS User Community

Figure 23. Estimated total building stock losses by county in New Jersey from Hurricane Sandy, October 29-30, 2012, using a level 1 HAZUS analysis of initial through final inundation estimates from $A$, October 31, 2012, B, November 11, 2012, and $C$, February 14, 2013, and $D$, the difference between February and October estimates. (HAZUS, HAZards United States) 


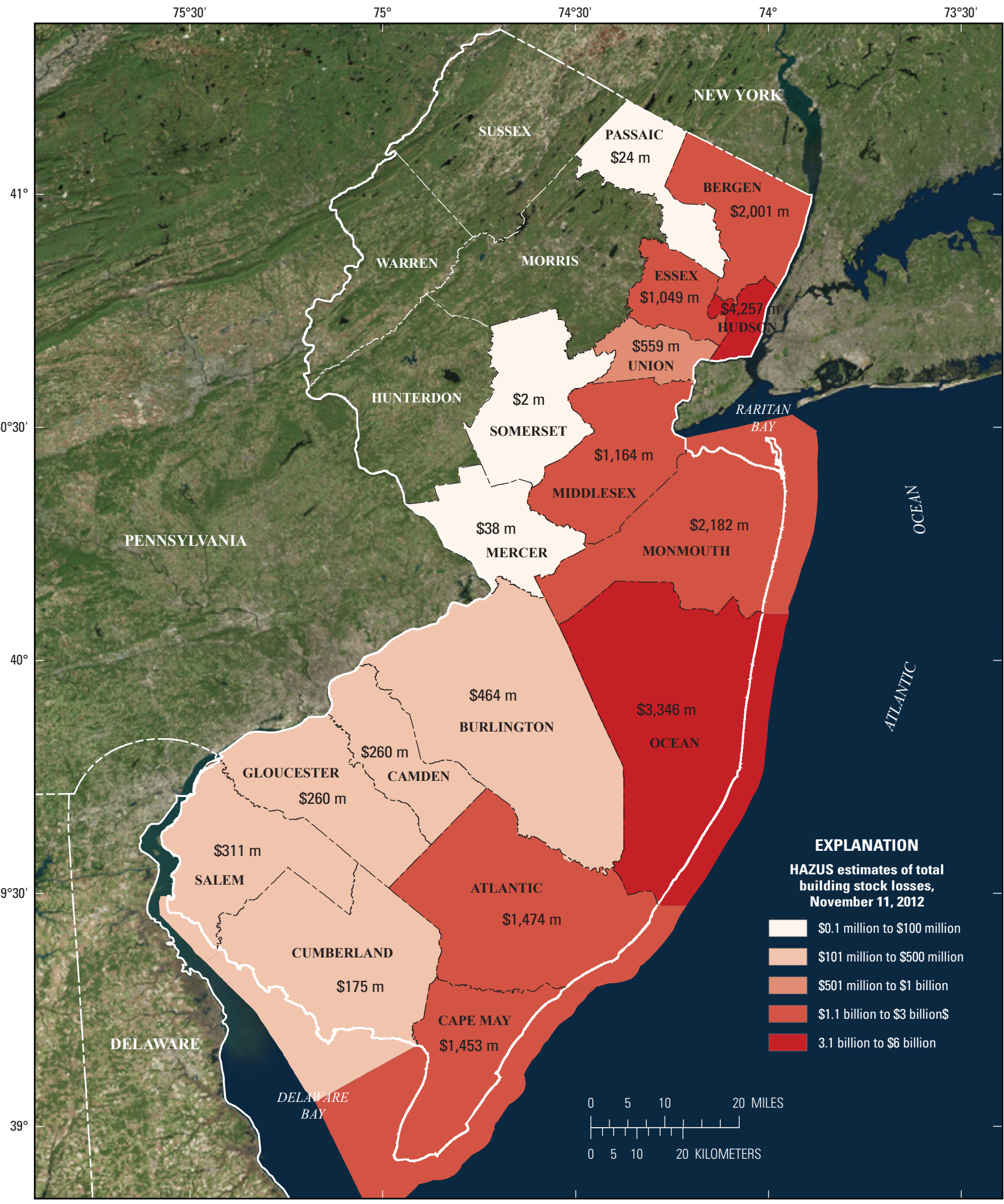

Base from Esri, DigitalGlobe, GeoEye, Earthstar Geographics, CNES/Airbus DS, USDA, USGS, AEX, Getmapping, Aerogrid, IGN, IGP, swisstopo, and the GIS User Community

Figure 23. Estimated total building stock losses by county in New Jersey from Hurricane Sandy, October 29-30, 2012, using a level 1 HAZUS analysis of initial through final inundation estimates from $A$, 0 ctober 31, 2012, B, November 11, 2012, and $C$, February 14, 2013, and $D$, the difference between February and October estimates. (HAZUS, HAZards United States)—Continued 
C

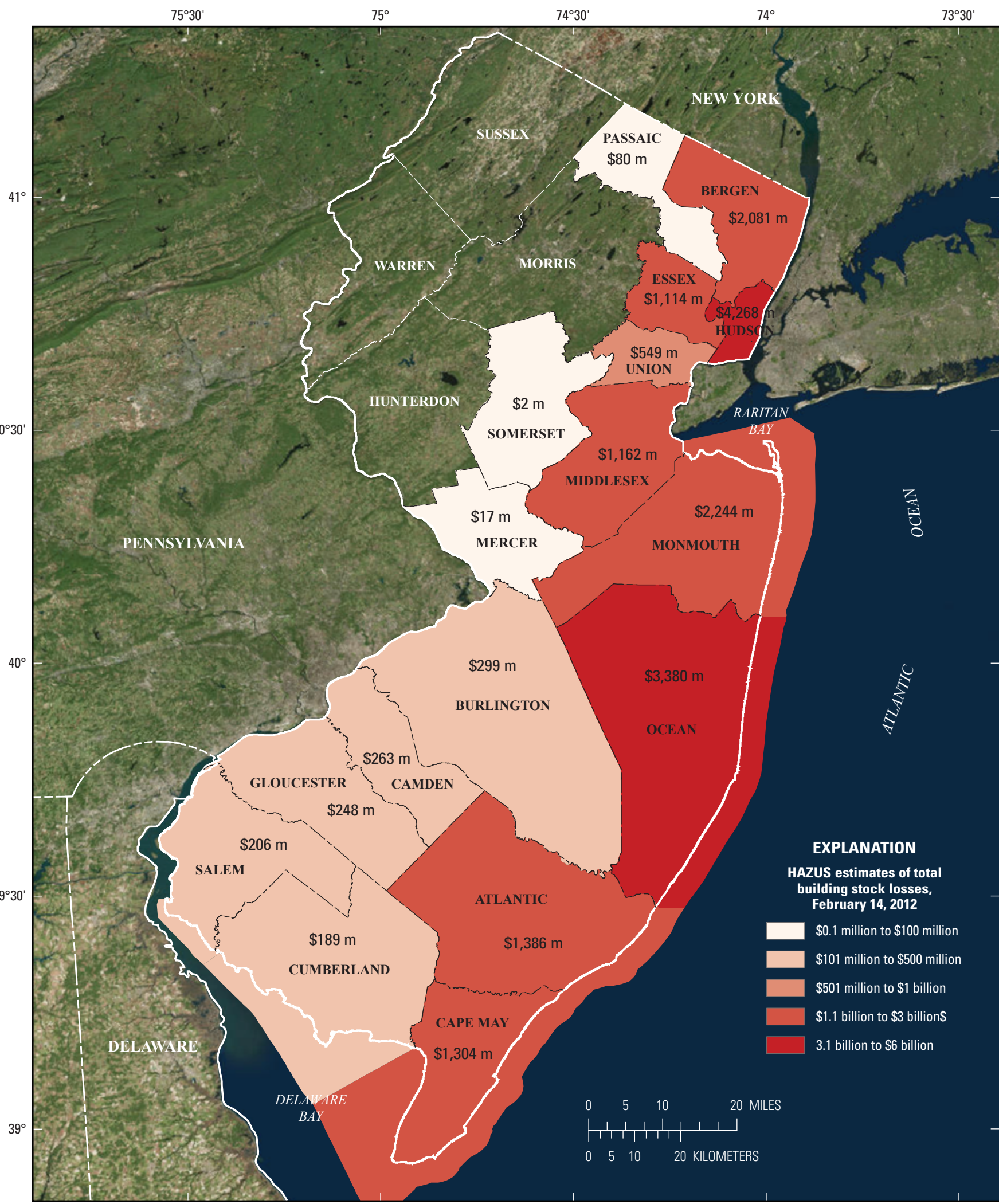

Base from Essi, DigitalGlobe, GeoEye, Earthstar Geographics, CNES/Airbus

DS, USDA, USGS, AEX, Getmapping, Aerogrid, IGN, IGP, swisstopo, and the GIS User Community

Figure 23. Estimated total building stock losses by county in New Jersey from Hurricane Sandy, October 29-30, 2012, using a level 1 HAZUS analysis of initial through final inundation estimates from $A$, October 31, 2012, B, November 11, 2012, and $C$, February 14, 2013, and $D$, the difference between February and October estimates. (HAZUS, HAZards United States)—Continued 


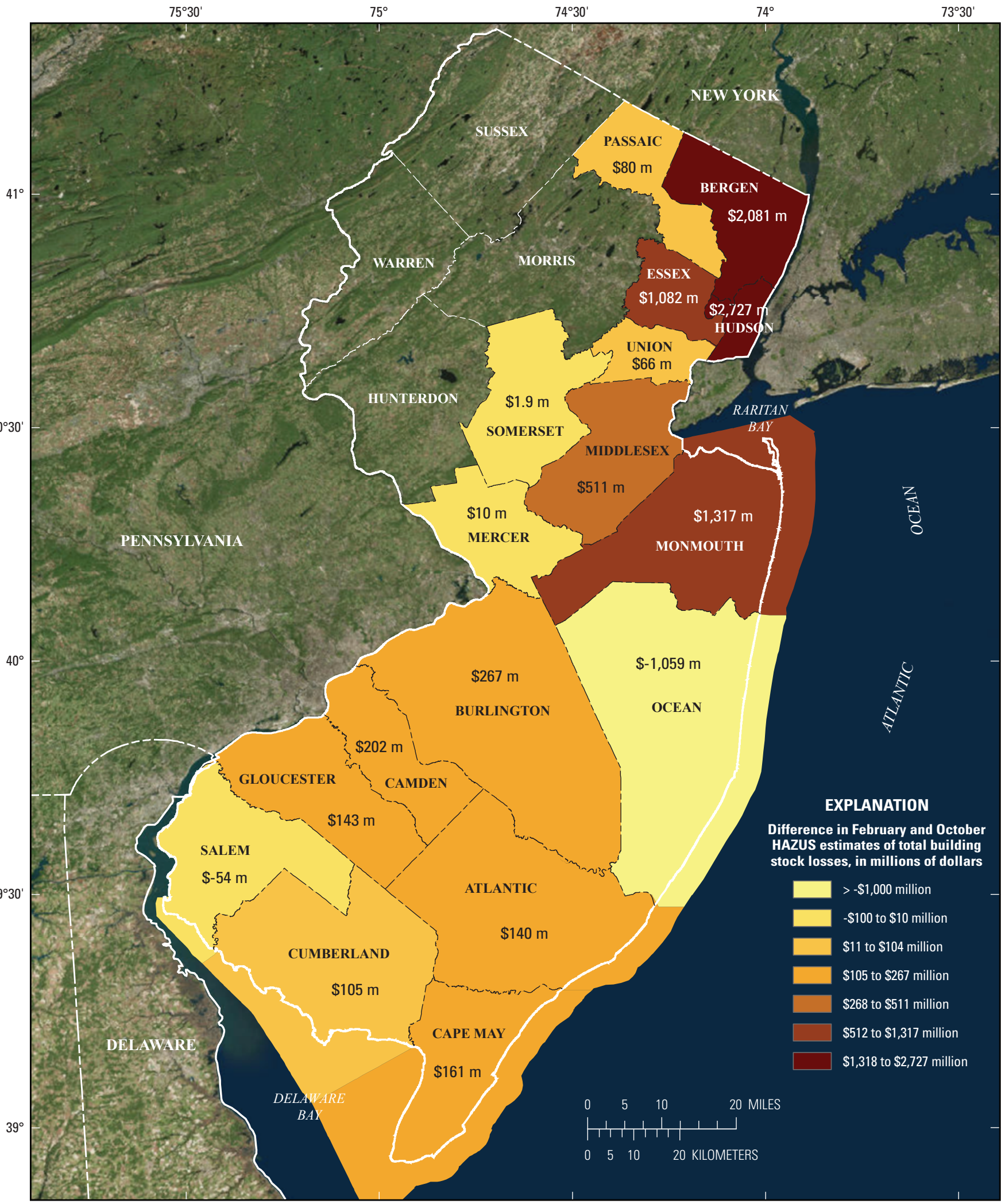

Base from Esri, DigitalGlobe, GeoEye, Earthstar Geographics, CNES/Airbus

DS, USDA, USGS, AEX, Getmapping, Aerogrid, IGN, IGP, swisstopo, and

the GIS User Community

Figure 23. Estimated total building stock losses by county in New Jersey from Hurricane Sandy, October 29-30, 2012, using a level 1 HAZUS analysis of initial through final inundation estimates from $A$, 0 ctober 31, 2012, B, November 11, 2012, and $C$, February 14, 2013, and $D$, the difference between February and October estimates. (HAZUS, HAZards United States)—Continued 


\section{General Description of Flood Damages}

Hurricane Sandy was the largest hurricane ever recorded in the North Atlantic and produced gale- to tropical stormforce winds along the coast of New Jersey and New York for 12-18 hours. After the storm made landfall in New Jersey, damages were estimated to be in the billions of dollars (fig. 24A-B). President Barack Obama asked the U.S. Congress for more than $\$ 60$ billion in Federal aid for New Jersey, New York, and other states hit by Hurricane Sandy. Initial news media reports estimated more than a dozen people died, and more than 7 million people were without power (FoxNews, 2012). Hurricane Sandy, referred to as "Superstorm Sandy" by the media, knocked out about 25 percent of the cell towers across 10 states on its way to making landfall in New Jersey. The day after the storm made landfall, the news media reported that an estimated 50 or more people were killed, 8.2 million households were without power, long lines of people waited for gas at stations with emergency backup power, and many New Jersey coastal communities suffered major damages (CSB News, 2012). Images of homes ripped off their footings, protective sand dunes washed away, miles of destroyed New Jersey boardwalk, and the breach in the barrier island at Mantoloking, N.J., were visible in many news media outlets after the storm. The backup generators of several hospitals were flooded and rendered useless after the storm. In the town of Moonachie, N.J., the news media reported that water levels rose about $5 \mathrm{ft}$ in less than an hour, trapping residents who had to be rescued by boat (CBS News, 2012). NOAA marked the end of the 2012 hurricane season on November 30 and noted that the 2012 season produced 19 named storms, 10 hurricanes, and 2 major hurricanes, including Hurricane Sandy. It also noted that 2012 was an above-normal Atlantic hurricane season but not an exceptional one (National Oceanic and Atmospheric Administration, 2012). Some selected photos and images are presented in figure $25 A-F$ and appendix 2 as visual documentation of the damages on the coast of New Jersey resulting from Hurricane Sandy.

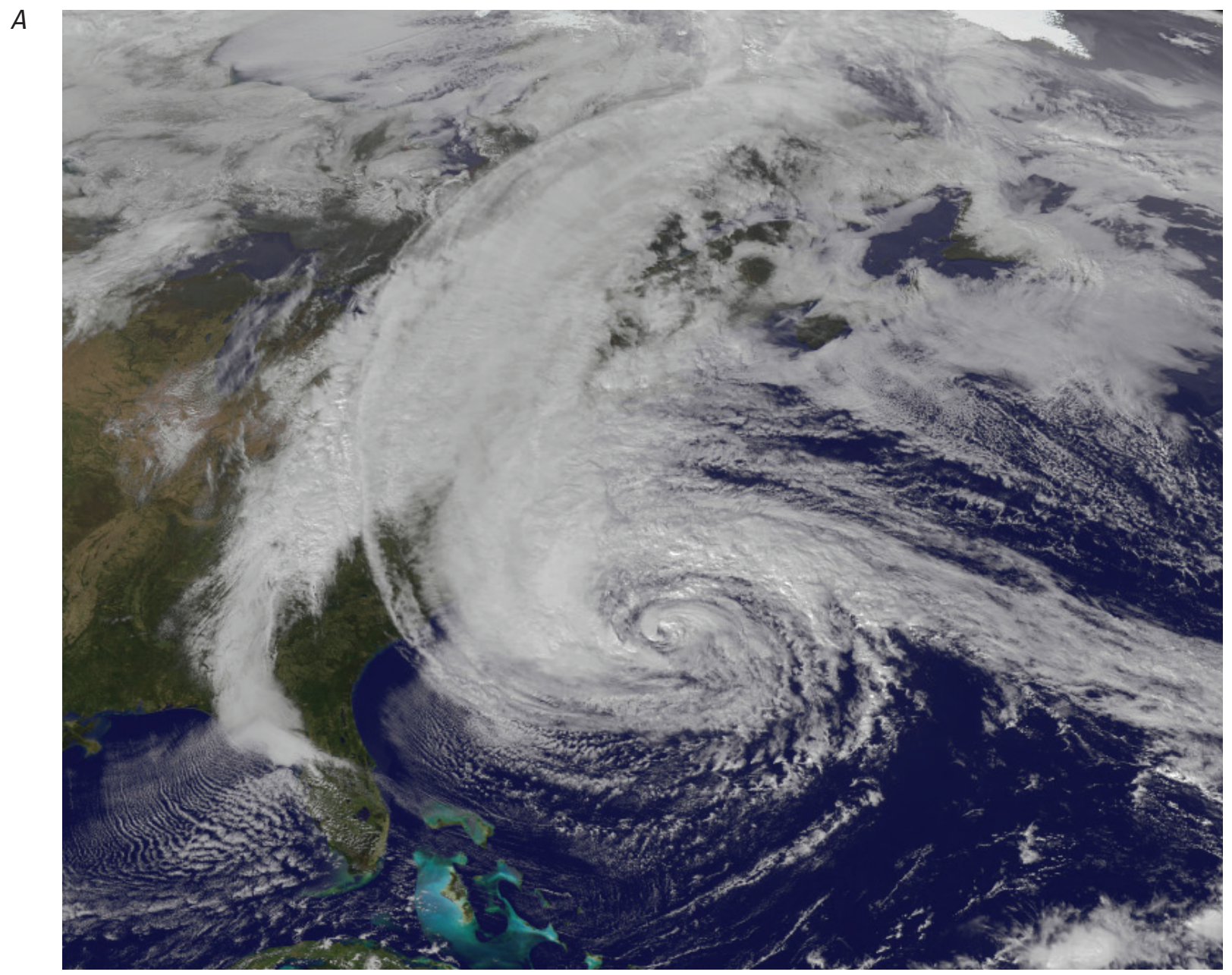

Figure 24. Satellite image of Hurricane Sandy $A$, on October 28, 2012, as it approached the coast of New Jersey, and $B$, over eastern United States showing the blackout in New Jersey and the surrounding area after making landfall in New Jersey. (Photos courtesy of NASA Earth Observatory) 
$B$

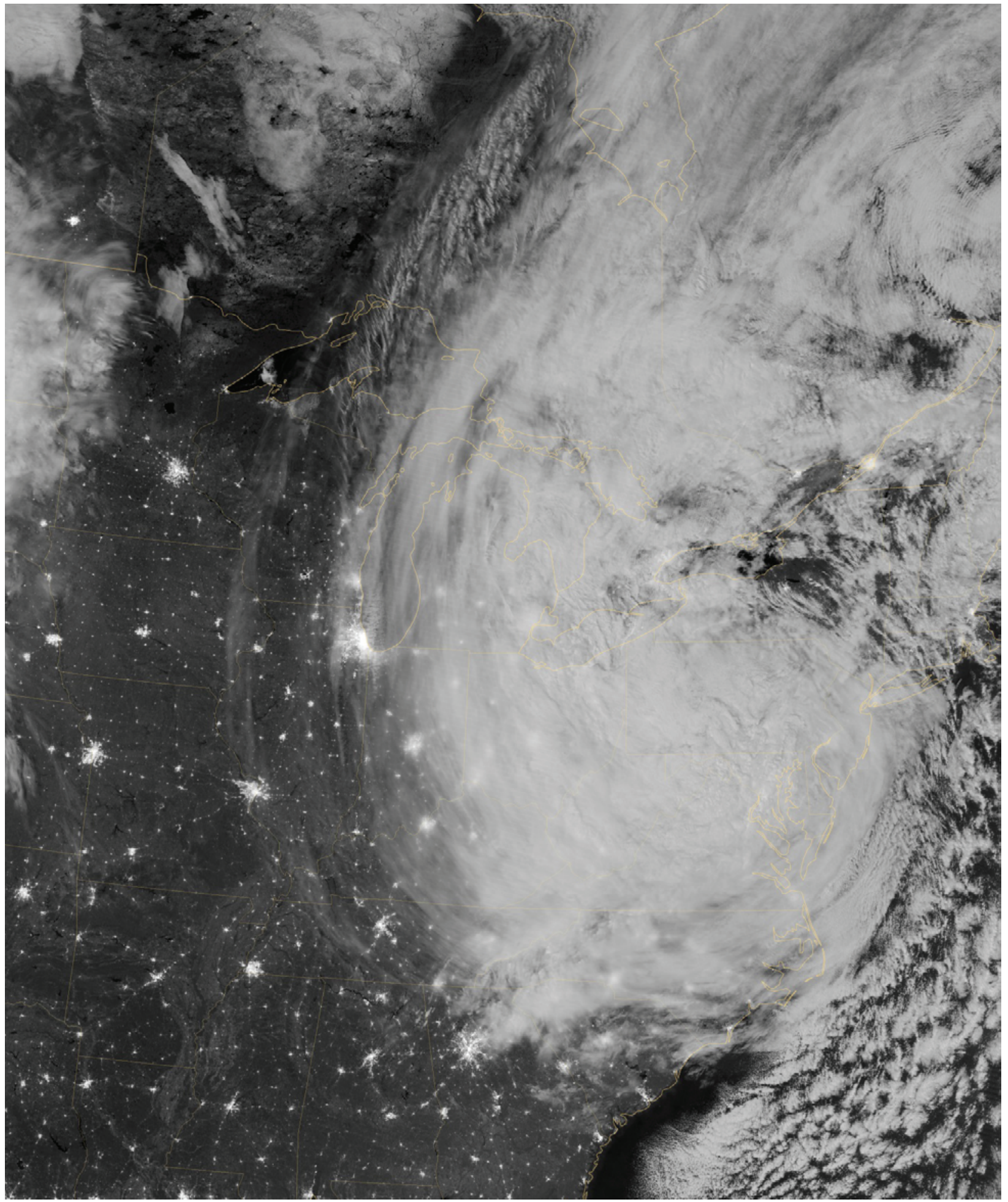

Figure 24. Satellite image of Hurricane Sandy $A$, on October 28, 2012, as it approached the coast of New Jersey, and $B$, over eastern United States showing the blackout in New Jersey and the surrounding area after making landfall in New Jersey. (Photos courtesy of NASA Earth Observatory)-Continued 
$A$
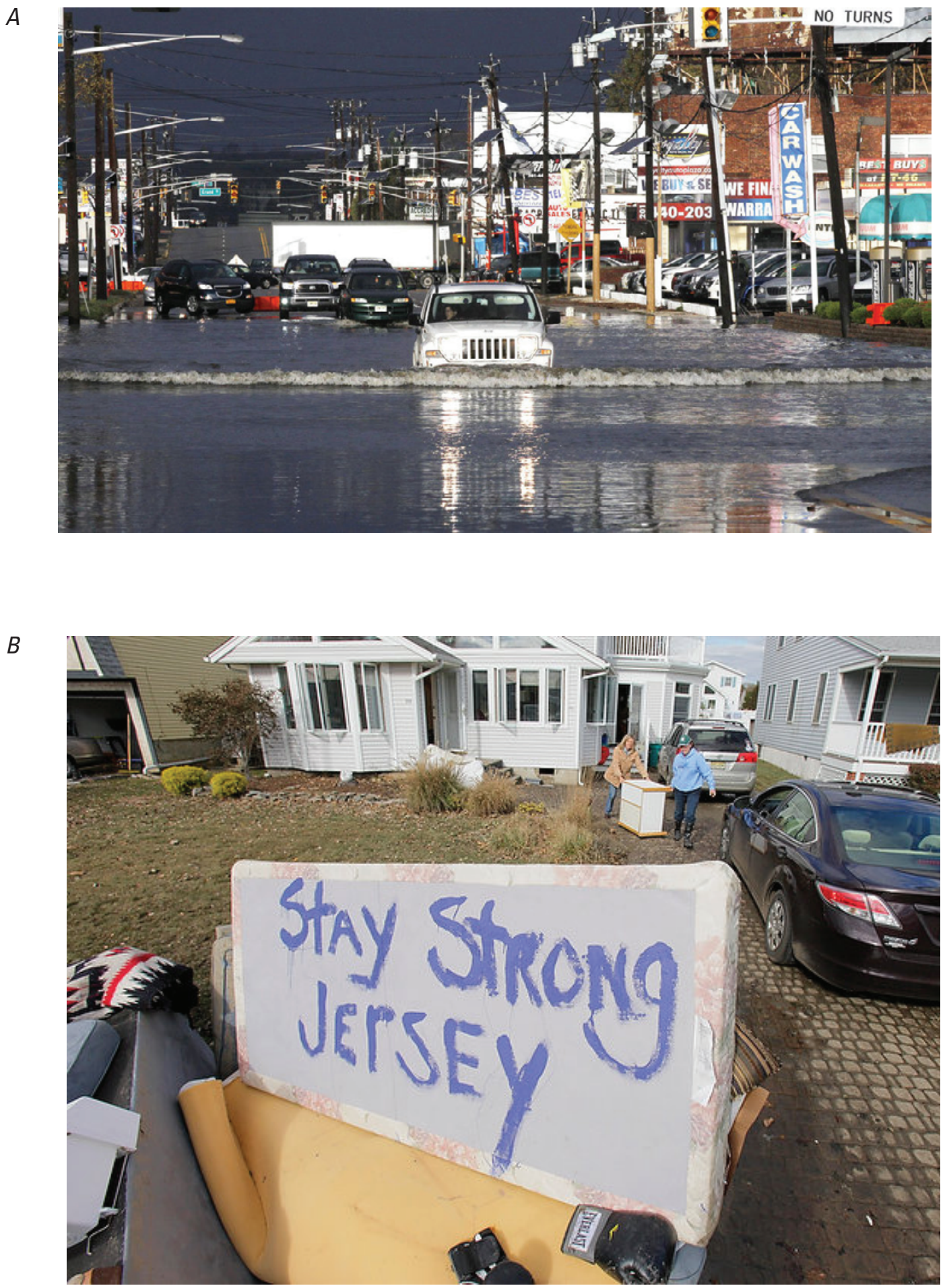

Figure 25. Flood damage from Hurricane Sandy in New Jersey: $A$, car trying to drive through flood waters on Route 46 in Little Ferry, $\mathrm{NJ}, 0$ ctober, 30, 2012, $B$, residents cleaning up debris and sending a message, $C$, damages in 0cean City and $D$, Birck Township, E, flooded streets of Hoboken, November 2, 2012, and F, massive debris pile at Seaside Heights Water Tower, November 5, 2012. Photographs $A$ and $B$ courtesy of the Star Ledger, William Pearlman and Tony Kurdzuk. Photograph $C$ courtesy of the South Jersey Times, photographer Tim Hawk. Photograph $D$ courtesy of NJ.com, photographer $A$. Mills. Photograph $E$ courtesy of NJ.com, submitted by a reader. Photograph $F$ courtesy of the Star Ledger, photographer David Gard. 
$C$

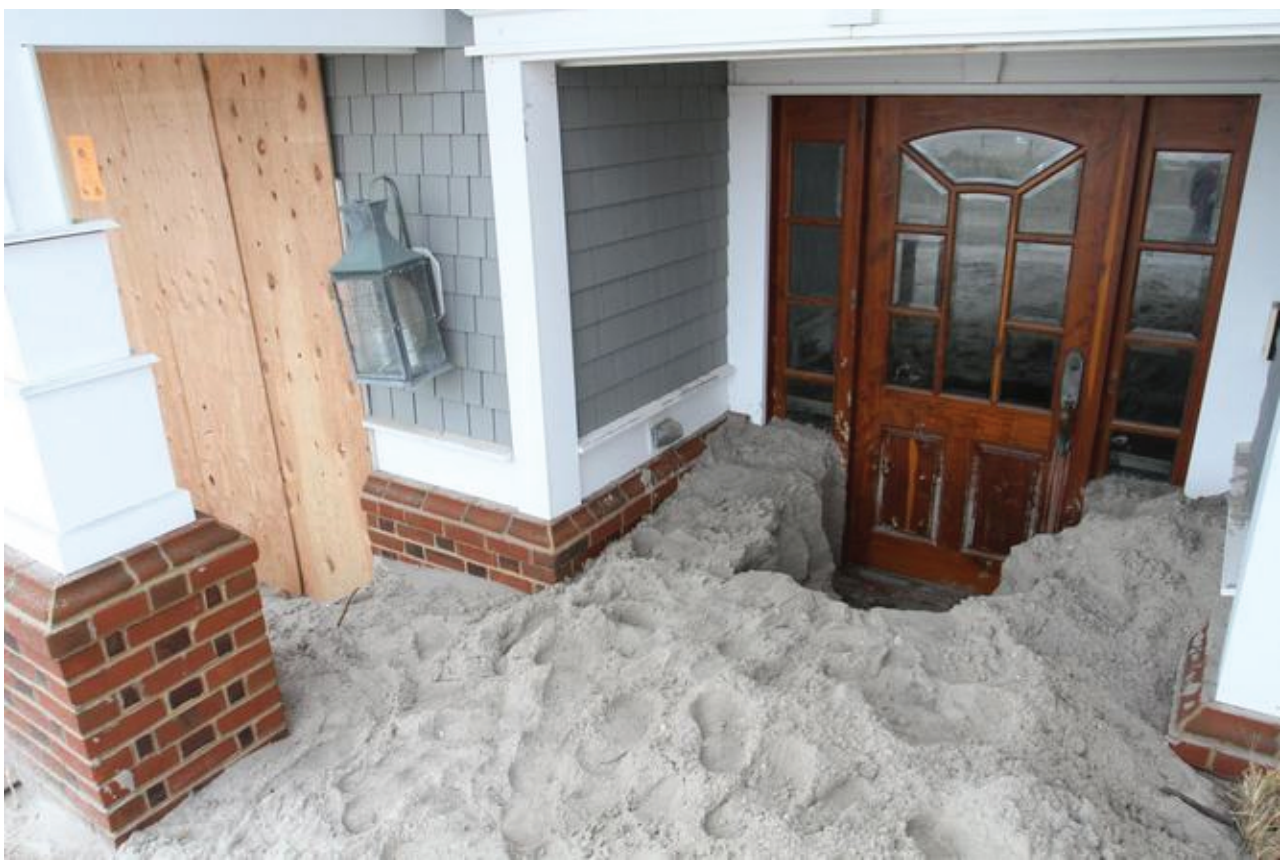

$D$

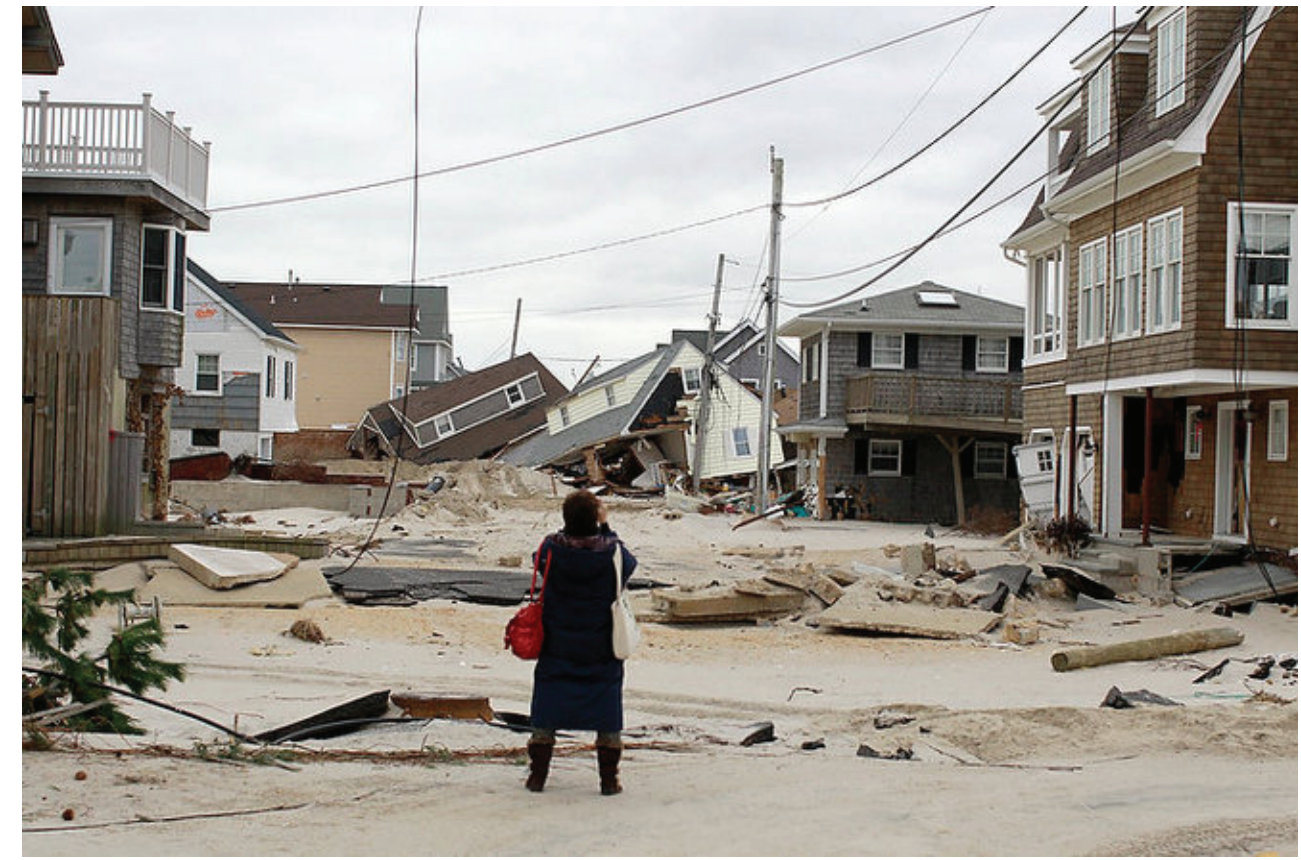

Figure 25. Flood damage from Hurricane Sandy in New Jersey: $A$, car trying to drive through flood waters on Route 46 in Little Ferry, $\mathrm{NJ}, 0$ ctober, 30, 2012, $B$, residents cleaning up debris and sending a message, $C$, damages in Ocean City and $D$, Birck Township, E, flooded streets of Hoboken, November 2, 2012, and F, massive debris pile at Seaside Heights Water Tower, November 5, 2012. Photographs $A$ and $B$ courtesy of the Star Ledger, William Pearlman and Tony Kurdzuk. Photograph $C$ courtesy of the South Jersey Times, photographer Tim Hawk. Photograph $D$ courtesy of NJ.com, photographer A. Mills. Photograph $E$ courtesy of NJ.com, submitted by a reader. Photograph $F$ courtesy of the Star Ledger, photographer David Gard.—Continued 

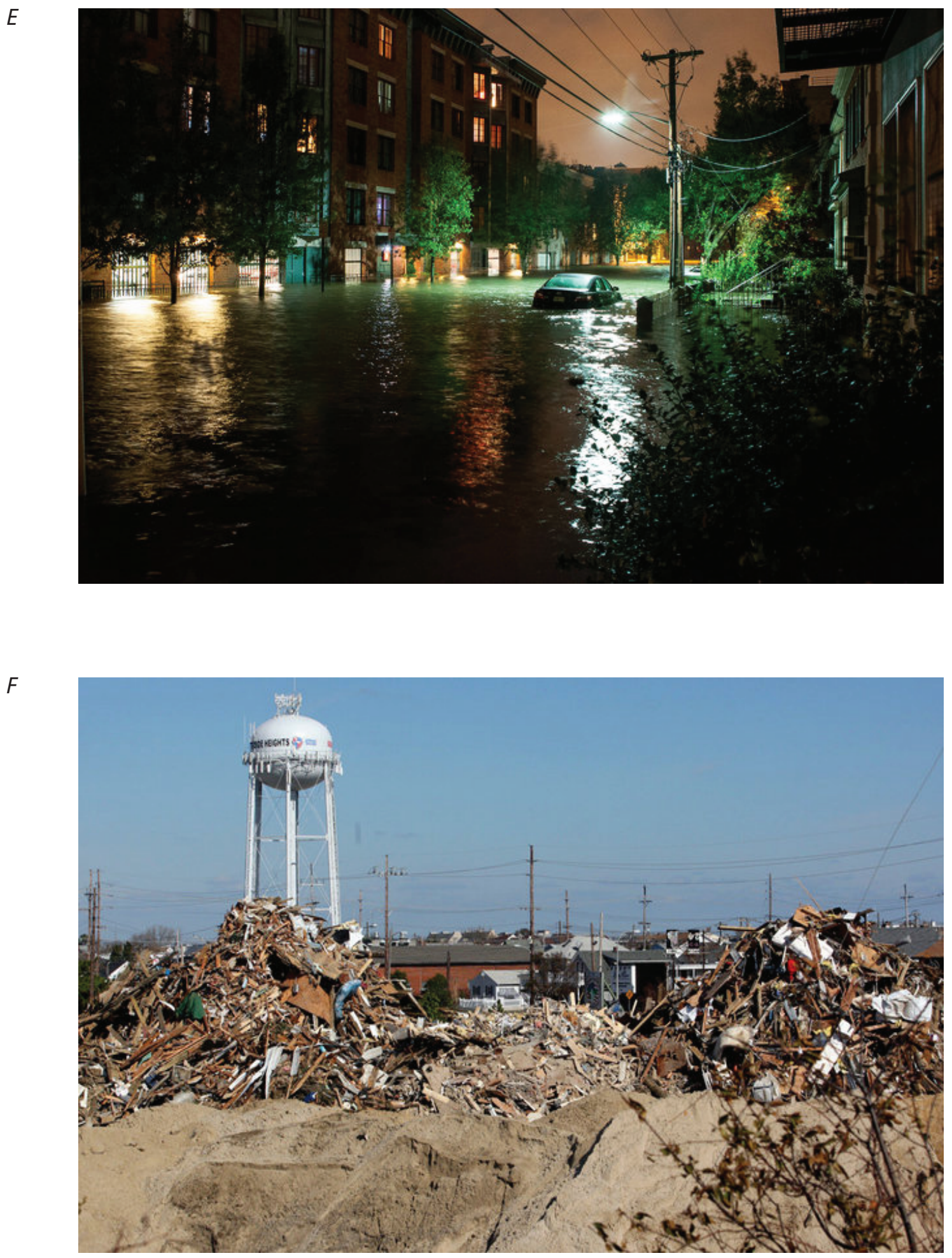

Figure 25. Flood damage from Hurricane Sandy in New Jersey: $A$, car trying to drive through flood waters on Route 46 in Little Ferry, $\mathrm{NJ}, 0$ ctober, 30, 2012, $B$, residents cleaning up debris and sending a message, $C$, damages in 0cean City and $D$, Birck Township, E, flooded streets of Hoboken, November 2, 2012, and F, massive debris pile at Seaside Heights Water Tower, November 5, 2012. Photographs $A$ and $B$ courtesy of the Star Ledger, William Pearlman and Tony Kurdzuk. Photograph $C$ courtesy of the South Jersey Times, photographer Tim Hawk. Photograph $D$ courtesy of NJ.com, photographer A. Mills. Photograph E courtesy of NJ.com, submitted by a reader. Photograph $F$ courtesy of the Star Ledger, photographer David Gard.—Continued 


\section{Summary and Conclusions}

By October 28, 2012, Hurricane Sandy had grown into the largest hurricane ever recorded in the North Atlantic and was tracking parallel to the east coast of United States, heading toward New Jersey. The storm transformed into a hybrid hurricane-nor'easter as it approached the coast of New Jersey and eventually made landfall near Atlantic City. Hurricane Sandy was the second largest hurricane on record after Hurricane Katrina, which devastated the Gulf coast in 2005. Several days before the storm made landfall, the U.S. Geological Survey (USGS) deployed a network of temporary storm-tide sensors to monitor water levels and barometric pressure and to record the timing, duration, areal extent, and magnitude of the storm tide and coastal flooding generated by Hurricane Sandy. In New Jersey, the temporary sensors were deployed to augment the existing New Jersey Tide Telemetry System (NJTTS). After the storm, the recorded time-series data were supplemented with the collection of high-water-mark (HWM) data to document the extent and depth of flooding along the coast. The deployment of temporary storm sensors and the post storm flagging and surveying of HWMs were done as a coordinated emergency response by the USGS in cooperation with the Federal Emergency Management Agency (FEMA). This scientific investigation report was prepared in cooperation with FEMA to document peak storm-tide elevations, estimated flood frequencies of peak storm-tide elevations, comparisons to historic coastal storms, and flood damages to assist in the understanding of the flood processes associated with coastal storms in New Jersey and to assist in future mitigation efforts.

Hurricane Sandy transitioned into a hybrid storm with a very large wind field as it followed a storm track that eventually turned the storm almost due west directly into the coast of New Jersey. This storm track directed sustained winds of more than 50-60 miles per hour ( $\mathrm{mph}$ ) from the east to areas north of the storm's eye that generated large peak storm tides and surge elevations along the coast of New Jersey and north to New York City. The NJTTS documented peak storm-tide elevations greater than 13 feet ( $\mathrm{ft}$ ) (referenced to the North American Vertical Datum of 1988) at locations in Raritan Bay and from greater than $5.5 \mathrm{ft}$ to almost $11 \mathrm{ft}$ at other locations along the coast of New Jersey. The peak storm-tide elevations documented for Hurricane Sandy were compared to the available elevation data for historic coastal storms. Comparisons to Hurricane Irene of 2011, the Great Nor'easter of 1992, and the 1962 Five-High hybrid storm showed that peak storm-tide elevations from Hurricane Sandy exceeded those from the historic storms at most locations along the coast of New Jersey.
Peak storm-tide data collected at the USGS tide gages, tidal crest-stage gages, temporary storm sensor locations, and HWM sites were compared to preliminary FEMA Coastal Flood Insurance Study flood elevations to estimate recurrence intervals (or annual exceedance probabilities). Preliminary study flood elevations for the 10-, 50-, 100-, and 500-year recurrence intervals (or the 10-, 2-, 1-, and 0.2-percent annual exceedance probabilities) were used to estimate the recurrence intervals of peak storm-tide elevations documented after the October 29-30, 2012, storm. The analysis showed peak stormtide elevations that exceeded the 100-year FEMA flood elevations in many parts of Middlesex, Union, Essex, Hudson and Bergen Counties, but Monmouth County stands out as having multiple locations that exceeded the 500-year recurrence interval. Peak storm-tide elevations in northern Ocean County were generally in the range of the 50- to 100-year recurrence intervals, whereas recurrence intervals from southern Ocean County to Cape May were generally less than 50 years (or greater than a 2-percent annual exceedance probability).

An analysis of the storm surge, generally defined as the calculated difference between the observed and predicted tide levels, was performed to document the relation between high tide, and peak storm tide and peak storm surge. The peak storm tide was determined to generally coincide with the predicted high tide at most locations along the central and northern coast of New Jersey. The peak storm surge was computed to be greater than $10 \mathrm{ft}$ in Raritan Bay and generally in the 6-8 $\mathrm{ft}$ range for selected USGS tide gages north of Barnegat Inlet. Where peak storm surge occurred nearly in phase with the predicted high tide, more extensive flooding and inundation of coastal communities resulted. The extent of inundation was estimated by FEMA using USGS peak storm-tide elevations and HWM data to calibrate a model that estimates storm-surge elevations. A hindcast inundation estimate and a final calibrated inundation estimate from FEMA were used by the USGS to estimate total building losses for New Jersey counties using HAZUS (HAZards United States). The results showed differences of about $\$ 8$ billion in estimated total building stock losses between the hindcast inundation and the final inundation. The total building losses for New Jersey were estimated at almost \$20 billion. Although a HAZUS building loss analysis is only an estimate of actual total building losses, it was clear that the use of USGS tide gage, temporary sensor, and HWM data substantially improved the HAZUS total building loss estimates. Ultimately, Hurricane Sandy produced higher peak storm-tide elevations and caused more damage along the northern coast of New Jersey than any other coastal storm in the 20th century. 


\section{References Cited}

Benson, M.A., and Dalrymple, Tate, 1967, General field and office procedures for indirect discharge measurements: U.S. Geological Survey Techniques of Water-Resources Investigations, book 3, chap. A1, $30 \mathrm{p}$.

CBSNews, 2012, Superstorm Sandy, accessed January 2013December 2014, at http://www.cbsnews.com/superstormsandy/.

Federal Emergency Management Agency, 2013a, FEMA Risk MAP Overview, accessed July 22, 2014, at https://www. rampp-team.com/index.htm.

Federal Emergency Management Agency, 2013b, FEMA Region II Coastal Mapping and Analysis, accessed June 2012-January 2015 at http://www.region2coastal.com/.

Federal Emergency Management Agency, 2013c, Coastal Flood Hazard Mapping Studies Fact Sheet, accessed June 11, 2013, at http://www.fema.gov/media-library/assets/ documents $/ 32751$ ? id $=7565 /$.

Federal Emergency Management Agency, 2013d, FEMA HAZUS, accessed August 29, 2013, at https://www.fema. gov/hazus.

Fox News, 2012, Over a dozen dead, over 7 million without power as Sandy pummels the East Coast, accessed October 1, 2013, at http://www.foxnews.com/weather/2012/10/29/ millions-across-east-coast-brace-for-uperstorm-sandy.

Lumia, Richard, Firda, G.D., and Smith, T.L., 2014, Floods of 2011 in New York: U.S. Geological Survey Scientific Investigations Report 2014-5058, 236 p.

McCallum, B.E., Wicklein, S.M., Reiser, R.G., Busciolano, Ronald, Morrison, Jonathan, Verdi, R.J., Painter, J.A., Frantz, E.R., and Gotvald, A.J., 2013, Monitoring storm tide and flooding from Hurricane Sandy along the Atlantic coast of the United States, October 2012: U.S. Geological Survey Open-File Report 2013-1043, 42 p., http://pubs.usgs.gov/ of $/ 2013 / 1043 /$.

McCormick, M.E., 2010, Ocean Engineering Mechanics: New York, Cambridge University Press, 575 p.

National Hurricane Center, 2013a, Saffir-Simpson Hurricane Wind Scale, accessed October 1, 2013, at http://www.nhc. noaa.gov/aboutsshs.shtml/.

National Hurricane Center, 2013b, Tropical cyclone report, Hurricane Sandy, accessed September 1-30, 2013, at http:// www.nhc.noaa.gov/data/.
National Hurricane Center, 2013c, Sea, Lake, and Overland Surges from Hurricanes (SLOSH), accessed October 1, 2013, at http://www.nhc.noaa.gov/surge/slosh.php/.

National Oceanic and Atmospheric Administration, 1999, National Geodetic Survey (NGS) Height Conversion program VERTCON, accessed March 11, 2013, at http://www. ngs.noaa.gov/TOOLS/Vertcon/vert_method.html.

National Oceanic and Atmospheric Administration, 2012, accessed March 11, 2013, at http://2010-2014.commerce. gov/blog/2012/11/29/noaa-busy-2012-hurricane-seasoncontinues-decades-long-high-activity-era-atlantic.html.

National Oceanic and Atmospheric Administration, 2013, accessed November 5, 2013, at http://tidesandcurrents.noaa. gov/est.

National Oceanic and Atmospheric Administration, 2015a, Hurricane Research Division, accessed September 25, 2015, at http://www.aoml.noaa.gov/hrd/tcfaq/D4.html.

National Oceanic and Atmospheric Administration, 2015b, National Weather Service, accessed December 20, 2015, at http:/www.nws.noaa.gov/om/winter/noreaster.shtml.

National Oceanic and Atmospheric Administration, 2015c, Science on a Sphere-Wave heights-Hurricane Sandy 2012, accessed October 02, 2015, at http://sos.noaa.gov/Datasets/ dataset.php?id=489.

Office of the New Jersey State Climatologist, 2011, August Overview 2011: Office of the State Climatologist, Center for Environmental Protection, School of Environmental and Biological Sciences, Rutgers University, New Jersey, assessed December 20, 2015, at http://climate.rutgers.edu/ stateclim/?section=menu\&\%20target=aug 11 .

Schubert, C.E., Busciolano, Ronald, Hearn, P.P., Jr., Rahav, A.N., Behrens, Riley, Finkelstein, Jason, Monti, Jack, Jr., and Simonson, A.E., 2015, Analysis of storm-tide impacts from Hurricane Sandy in New York: U.S. Geological Survey Scientific Investigations Report 2015-5036, 75 p.

Suro, T.P., 1998, Summary of floods in the United States, January 1992 through September 1993, Summary of Flooding December 11-12, 1992, in New Jersey: U.S. Geological Survey Water Supply Paper 2499, p. 165-171.

Suro, T.P., Firda, G.D., and Szabo, C.O., 2009, Flood of June 26-29, 2006, Mohawk, Delaware, and Susquehanna River Basins, New York: U.S. Geological Survey Open-File Report 2009-1063, 354 p.

Thomas, D.M., and Edelen, Jr, G.W., 1962, Tidal floods, Atlantic City and vicinity, New Jersey: U.S. Geological Survey Hydrologic Atlas H-65, 1 pl. 
Turner, J.L., 2005, Seven superstorms of the Northeast: Harvey Cedars, N.J., Down The Shore Publishing, 182 p.

U.S. Army Engineering Division, North Atlantic Division Corp. of Engineers, 1963, Operation Five-High, March 1962 Storm: Report on Operation Five-High 1963 [not paginated].

Watson, K.M., Collenburg, J.V., and Reiser, R.G., 2013, Hurricane Irene and associated floods of August 27-30, 2011, in New Jersey: U.S. Geological Survey Scientific Investigations Report 2013-5234, 149 p. 


\section{Appendixes 1, 2}

Appendix 1

Saffir-Simpson Hurricane Wind Scale.

\section{Appendix 2}

Storm and Damage Photographs. 


\section{Appendix 1}

\section{Saffir-Simpson Hurricane Wind Scale}

The Saffir-Simpson Hurricane Wind Scale is a 1 to 5 rating based on a hurricane's sustained wind speed. This scale estimates potential property damage. Hurricanes reaching Category 3 and higher are considered major hurricanes because of their potential for significant loss of life and damage. Category 1 and 2 storms are still dangerous, however, and require preventative measures. In the western North Pacific, the term "super typhoon" is used for tropical cyclones with sustained winds exceeding $150 \mathrm{mph}$.

Category

1

1

$96-110 \mathrm{mph}$
$83-95 \mathrm{kt}$
$154-177 \mathrm{~km} / \mathrm{h}$

3

(major)

111-129 mph

$178-208 \mathrm{~km} / \mathrm{h}$

$\begin{array}{cl}4 & 130-156 \mathrm{mph} \\ \text { (major) } & 113-136 \mathrm{kt} \\ & 209-251 \mathrm{~km} / \mathrm{h}\end{array}$

$\begin{array}{cl}5 & 157 \mathrm{mph} \text { or higher } \\ \text { (major) } & 137 \mathrm{kt} \text { or higher } \\ & 252 \mathrm{~km} / \mathrm{h} \text { or higher }\end{array}$

64-82 kt

$119-153 \mathrm{~km} / \mathrm{h}$

209-251 km/h
74-95 mph

Data provided by: NOAA/ National Weather Service

National Centers for Environmental Prediction

National Hurricane Center
Very dangerous winds will produce some damage: Well-constructed frame homes could have damage to roof, shingles, vinyl siding and gutters. Large branches of trees will snap and shallowly rooted trees may be toppled. Extensive damage to power lines and poles likely will result in power outages that could last a few to several days.

Extremely dangerous winds will cause extensive damage: Well-constructed frame homes could sustain major roof and siding damage. Many shallowly rooted trees will be snapped or uprooted and block numerous roads. Near-total power loss is expected with outages that could last from several days to weeks.

Devastating damage will occur: Well-built framed homes may incur major damage or removal of roof decking and gable ends. Many trees will be snapped or uprooted, blocking numerous roads. Electricity and water will be unavailable for several days to weeks after the storm passes.

Catastrophic damage will occur: Well-built framed homes can sustain severe damage with loss of most of the roof structure and/or some exterior walls. Most trees will be snapped or uprooted and power poles downed. Fallen trees and power poles will isolate residential areas. Power outages will last weeks to possibly months. Most of the area will be uninhabitable for weeks or months.

Catastrophic damage will occur: A high percentage of framed homes will be destroyed, with total roof failure and wall collapse. Fallen trees and power poles will isolate residential areas. Power outages will last for weeks to possibly months. Most of the area will be uninhabitable for weeks or months. 


\section{Appendix 2}

\section{Storm and Damage Photographs}
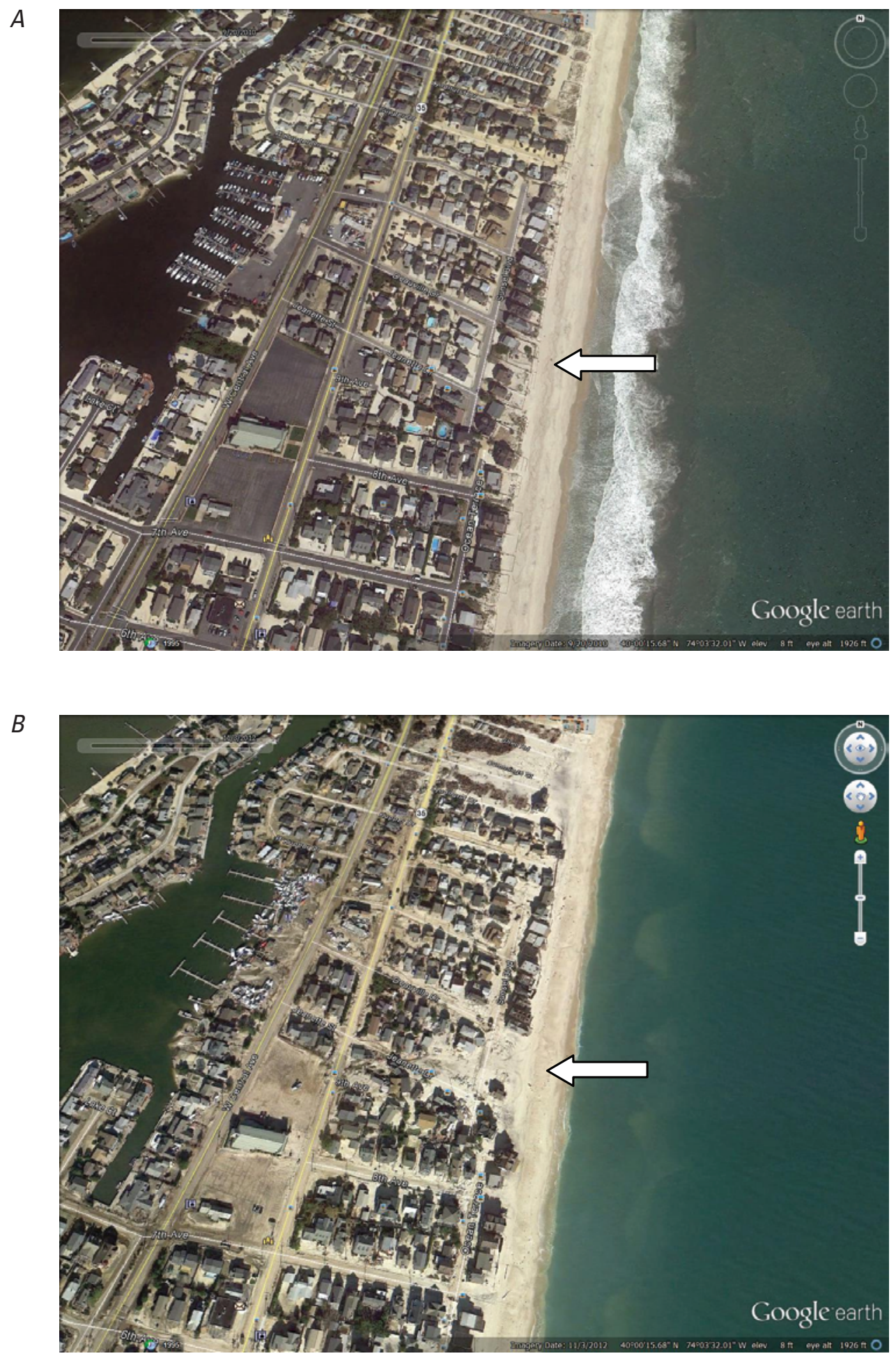

Photographs of Normandy Beach, NJ, A, taken in September 2010 before Hurricane Sandy hit the coast of New Jersey, $B$, taken November 2012 after Hurricane Sandy caused major damage to the coast of New Jersey. (Arial Images courtesy of Google Earth) 

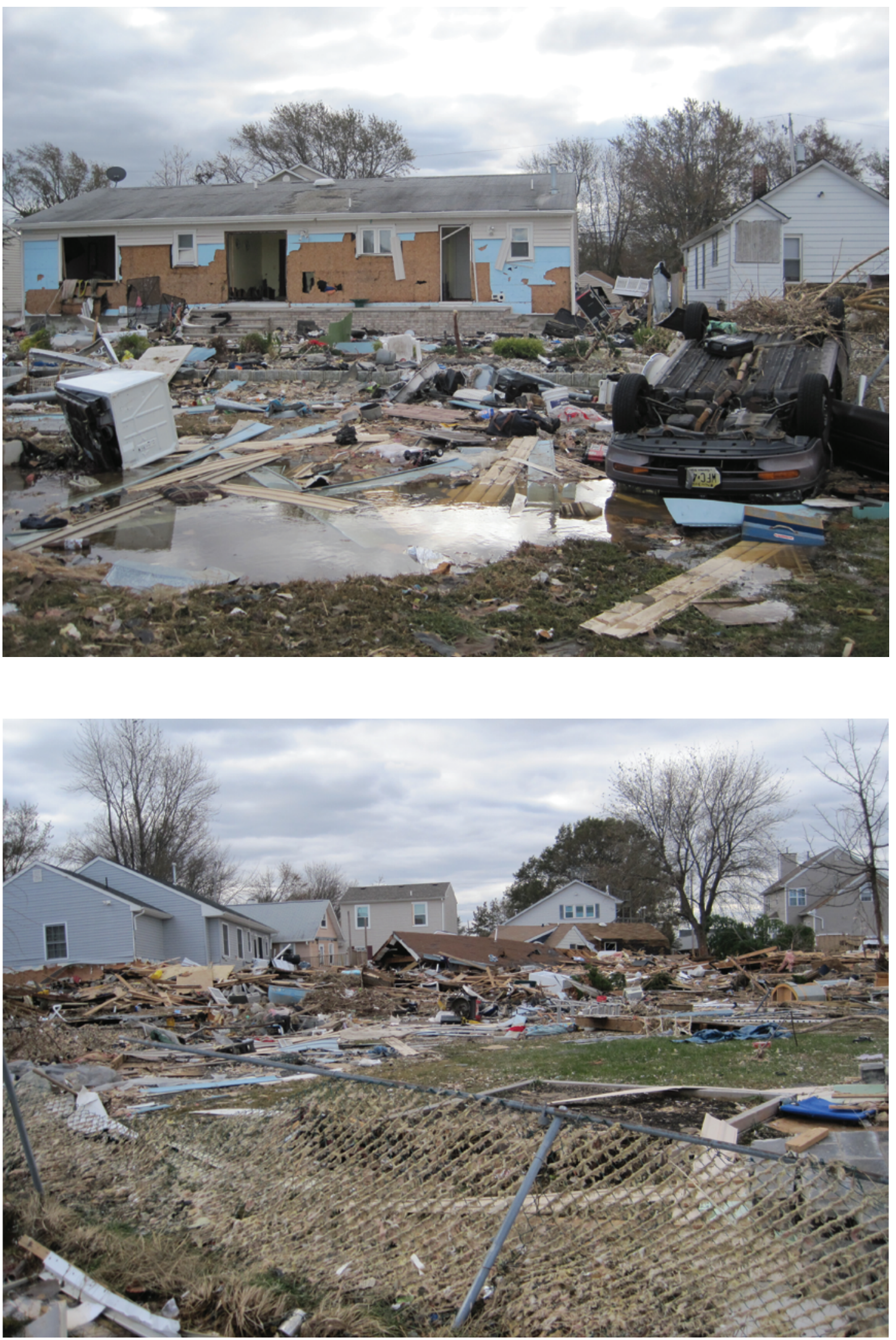

Union Beach, NJ, homes heavily damaged or destroyed during Hurricane Sandy, photos taken November 6, 2012.

(Photos by Carrie Huitger, USGS) 


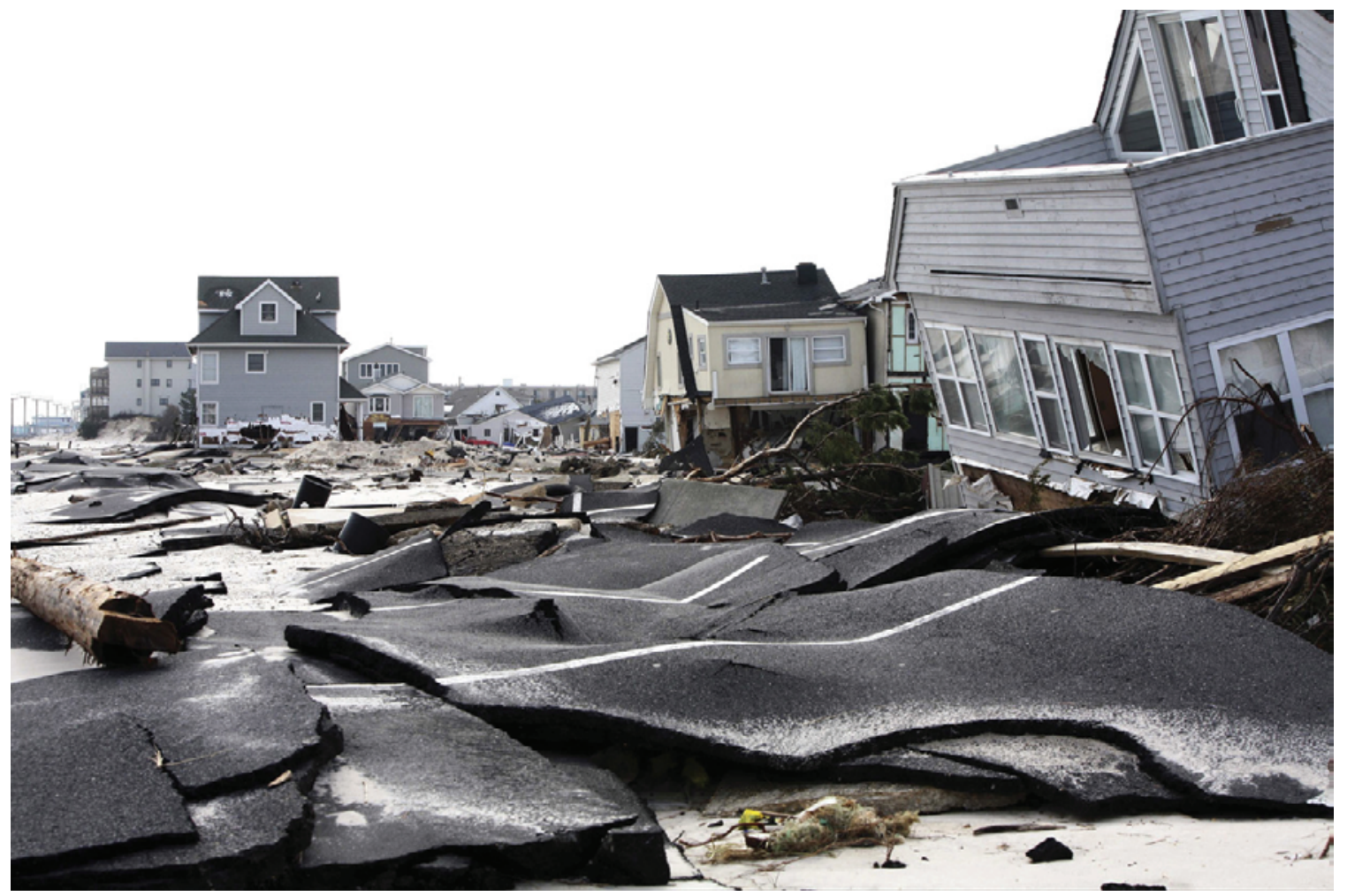

Damaged streets and homes in Ortley Beach, NJ. Photo taken November 10, 2012.

(Photo courtesy of the Governor's office, photographer Tim Larsen)

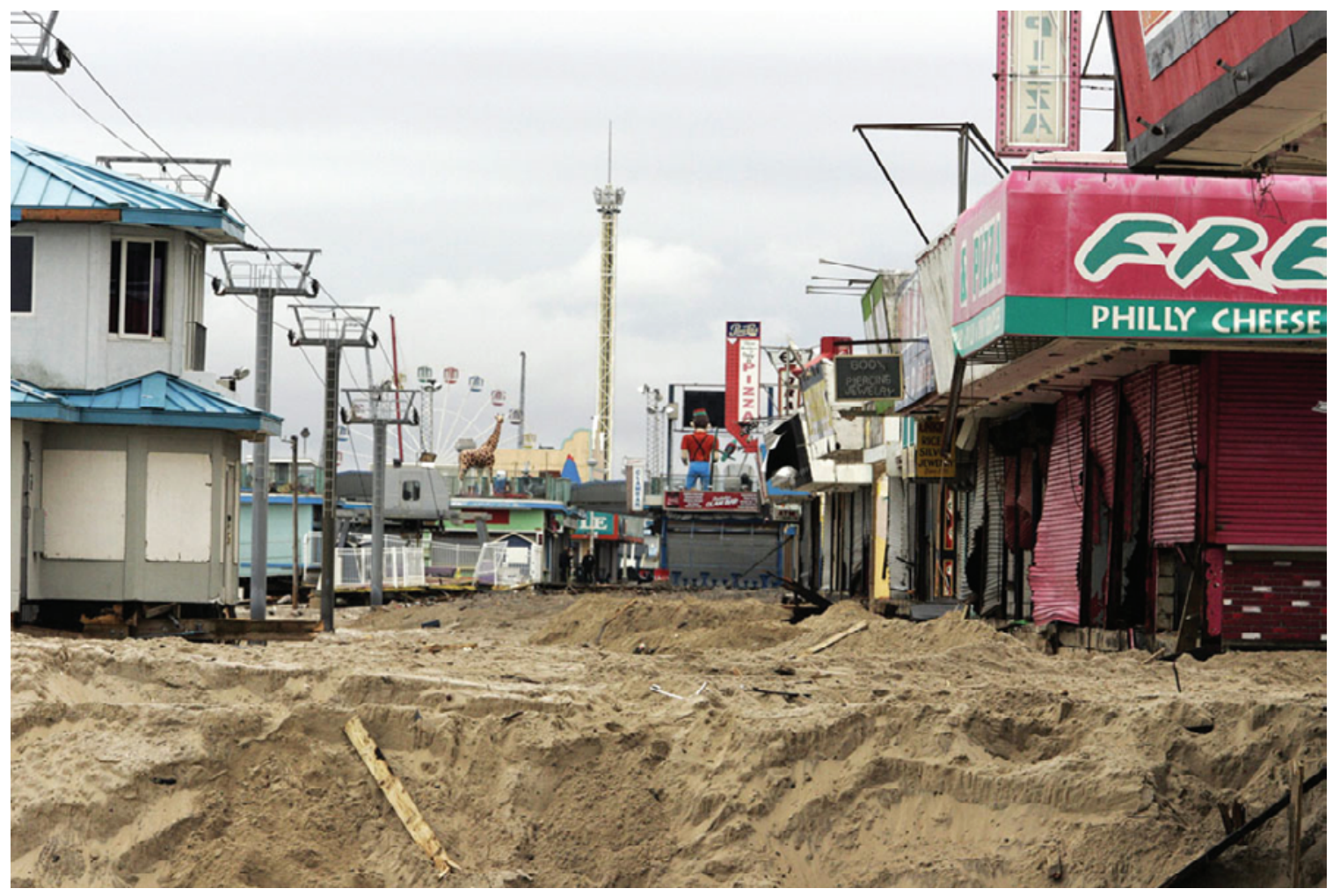

Boardwalk in Seaside Heights damaged after Hurricane Sandy. Photo taken November 13, 2012.

(Photo courtesy of Reuters, photographer Tom Mihalek) 

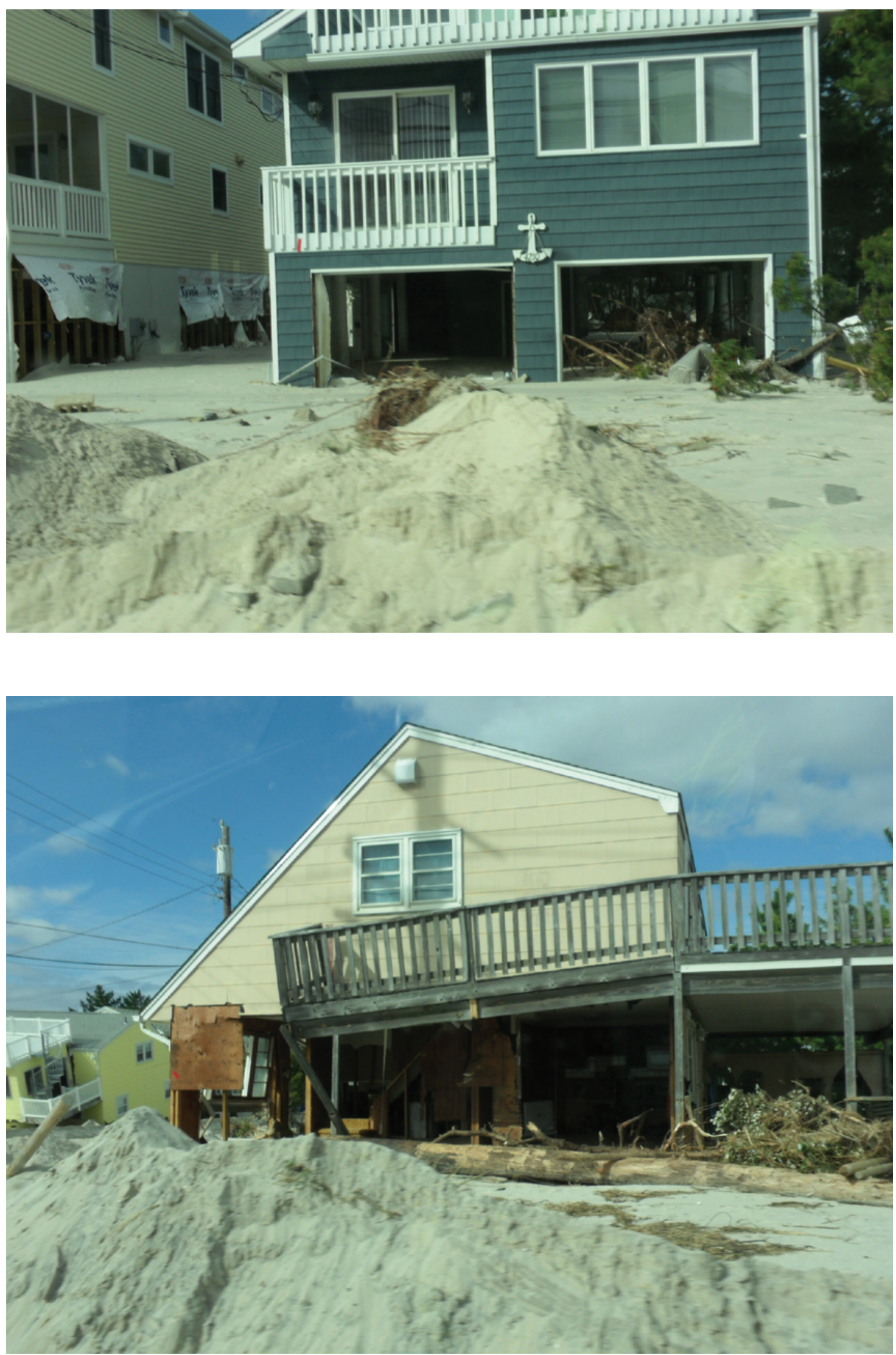

Homes on Long Beach Island inundated with sand and severely damaged during Hurricane Sandy. Photo taken November 6, 2012. (Photos by Andrew Ebner, USGS) 

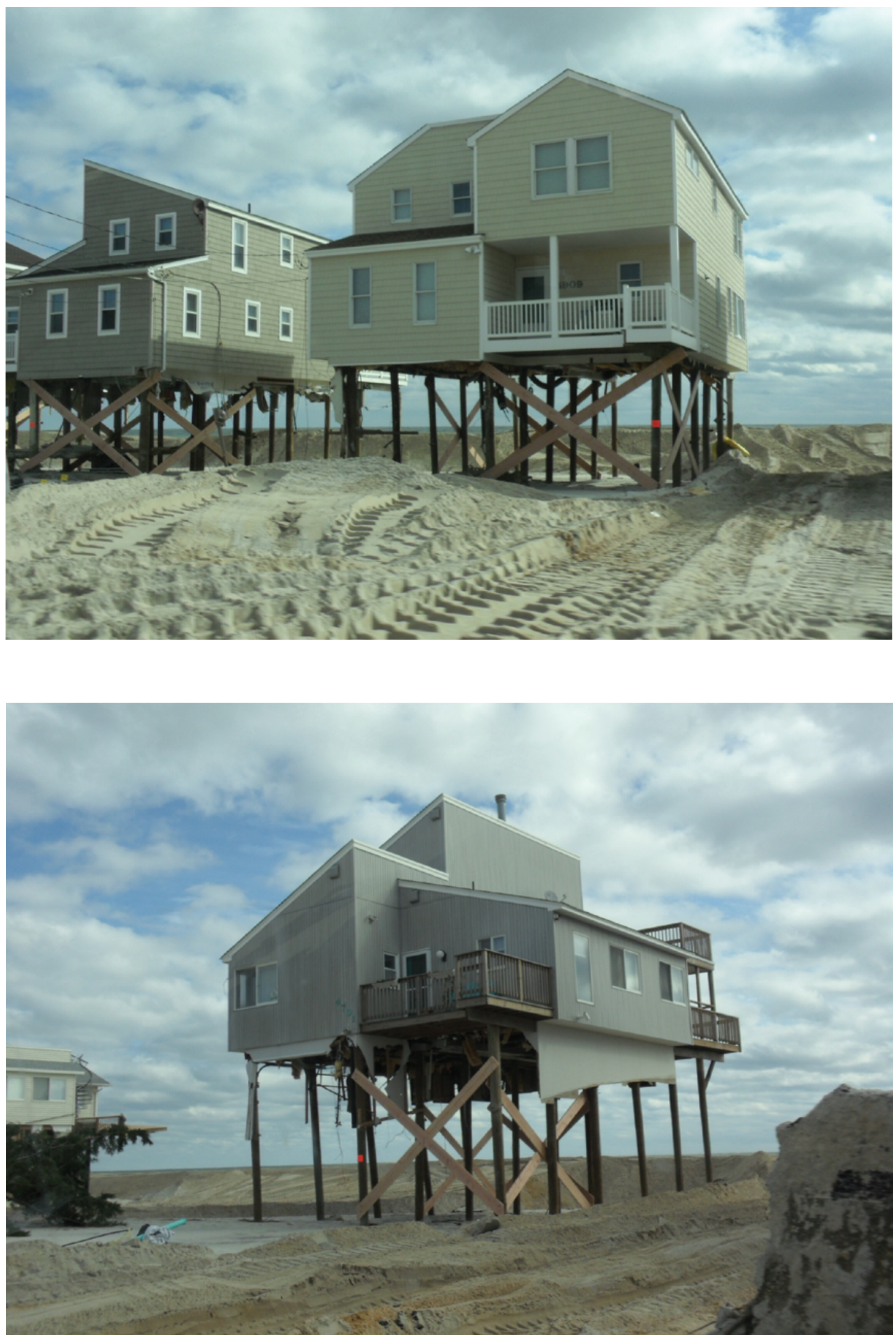

Significant erosion around elevated homes on Long Beach Island, NJ, resulting from Hurricane Sandy. Photos taken November 6, 2012. (Photos by Andrew Ebner, USGS) 


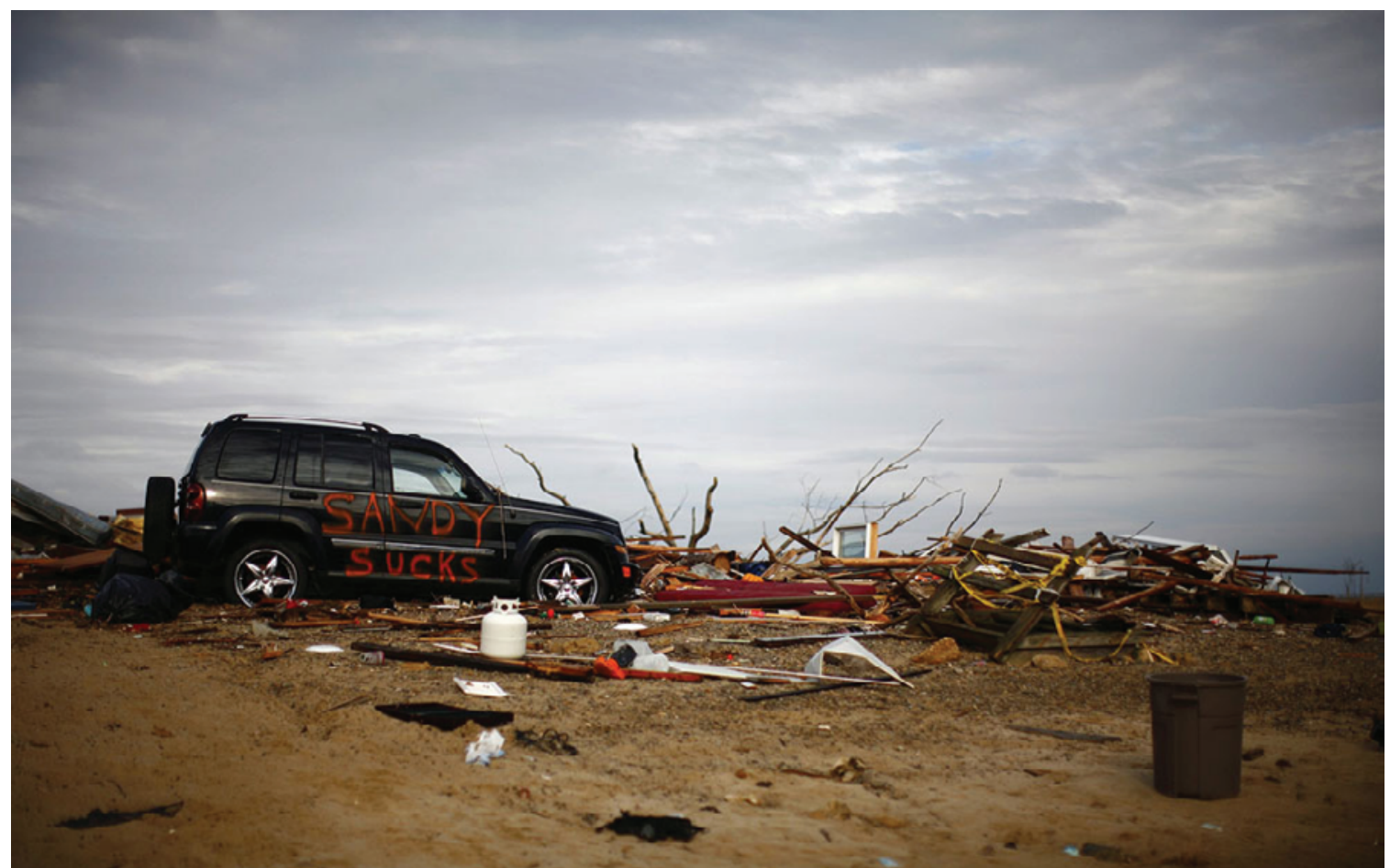

Car parked at ruins of home that was severely damaged by Hurricane Sandy. Photo taken November 13, 2012. (Photo courtesy of Reuters, photographer Eric Thayer)

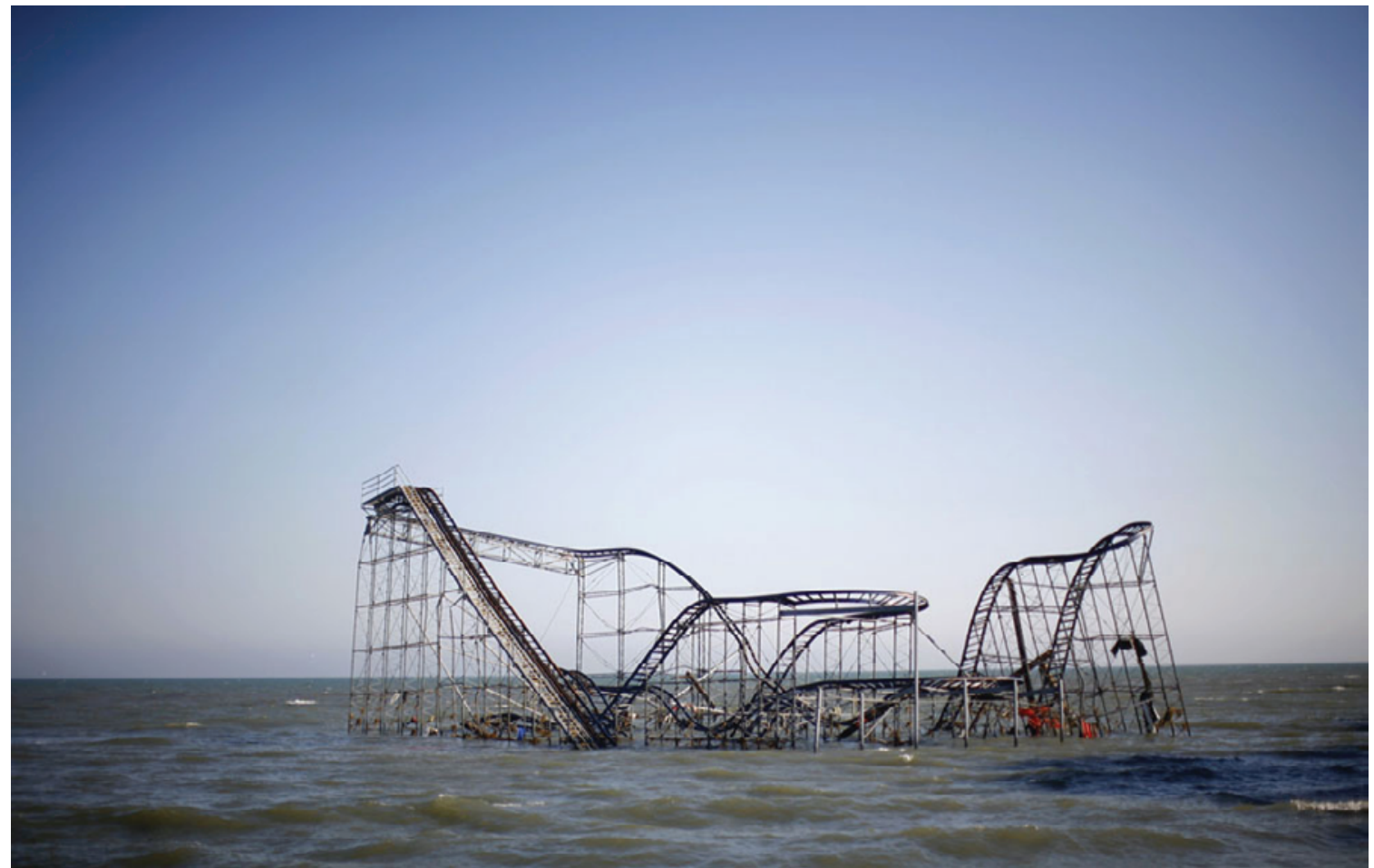

Remains of Star Jet roller coaster that was part of Casino Pier amusement park in Seaside Heights, NJ. Photo taken November 11, 2012. (Photo courtesy of Reuters, photographer Eric Thayer) 


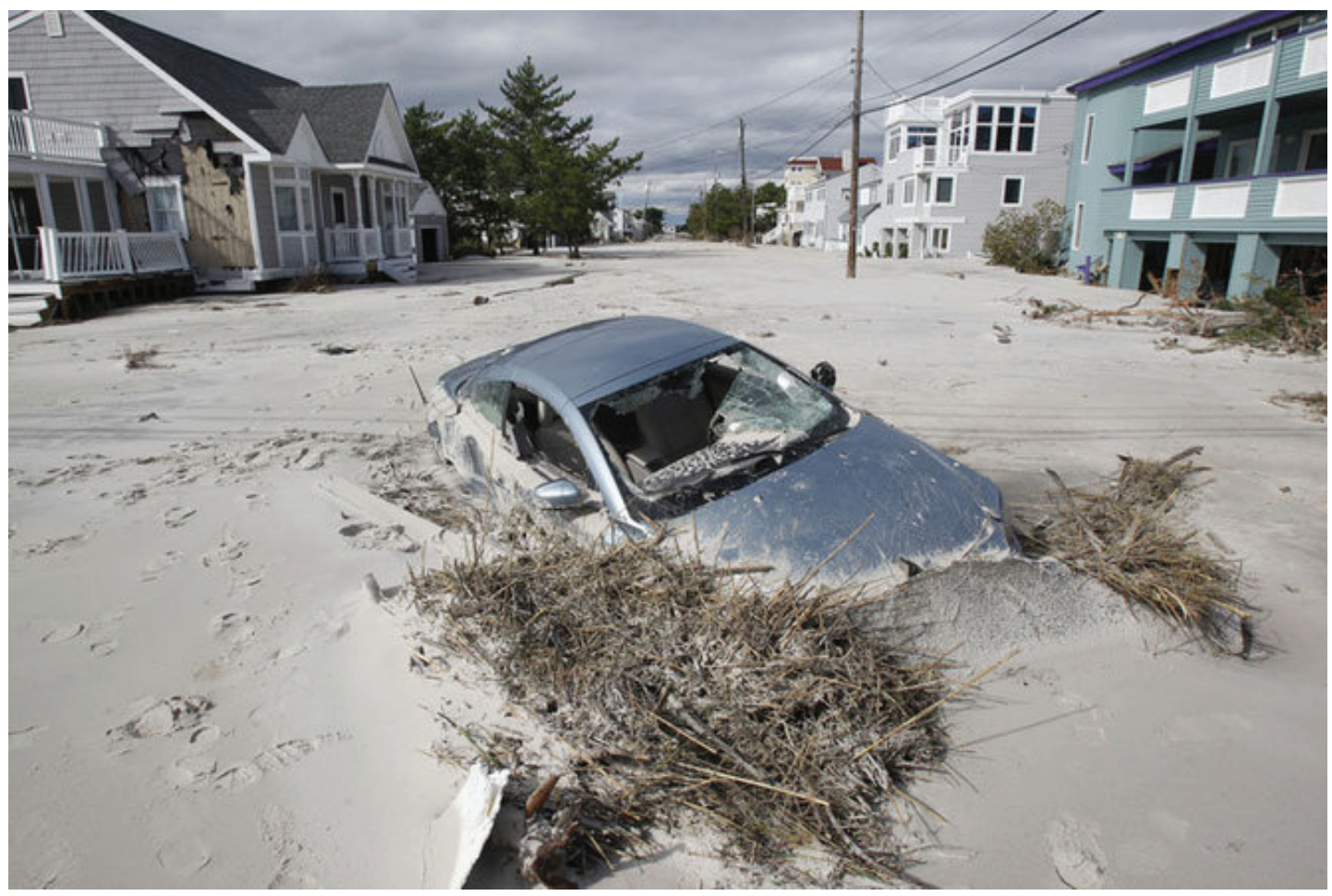

A car buried in sand at the intersection of Carolina Ave. and Long Beach Blvd. in the Holgate section of Long Beach Island, NJ. Photo taken October 31, 2012. (Photo courtesy of The Star-Ledger, photographer Noah K. Murray)

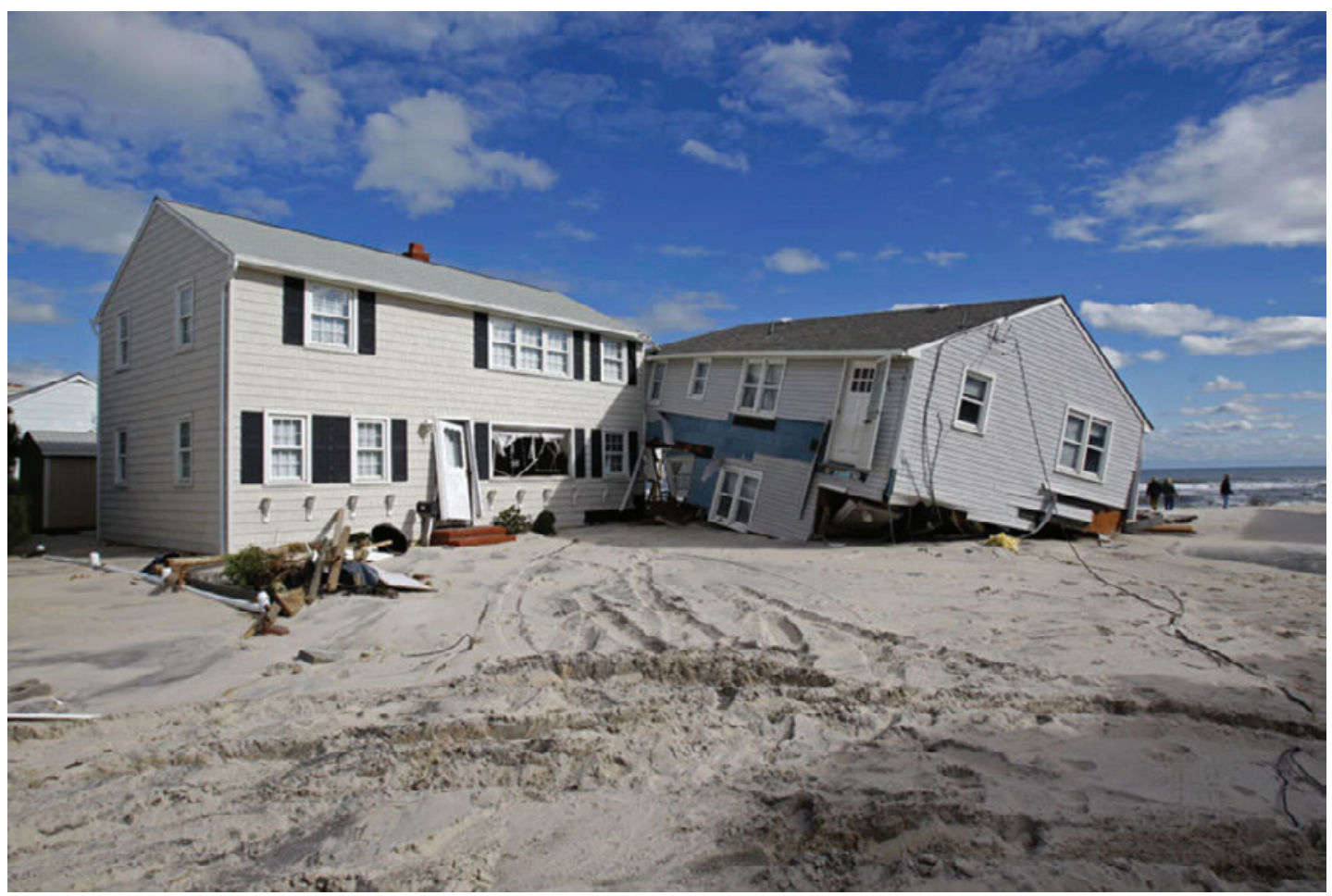

A home forced into another by Hurricane Sandy in the Holgate section of Long Beach Island, NJ. Photo taken October 31, 2012. (Photocourtesy of The Star-Ledger, photographer Noah K. Murray) 


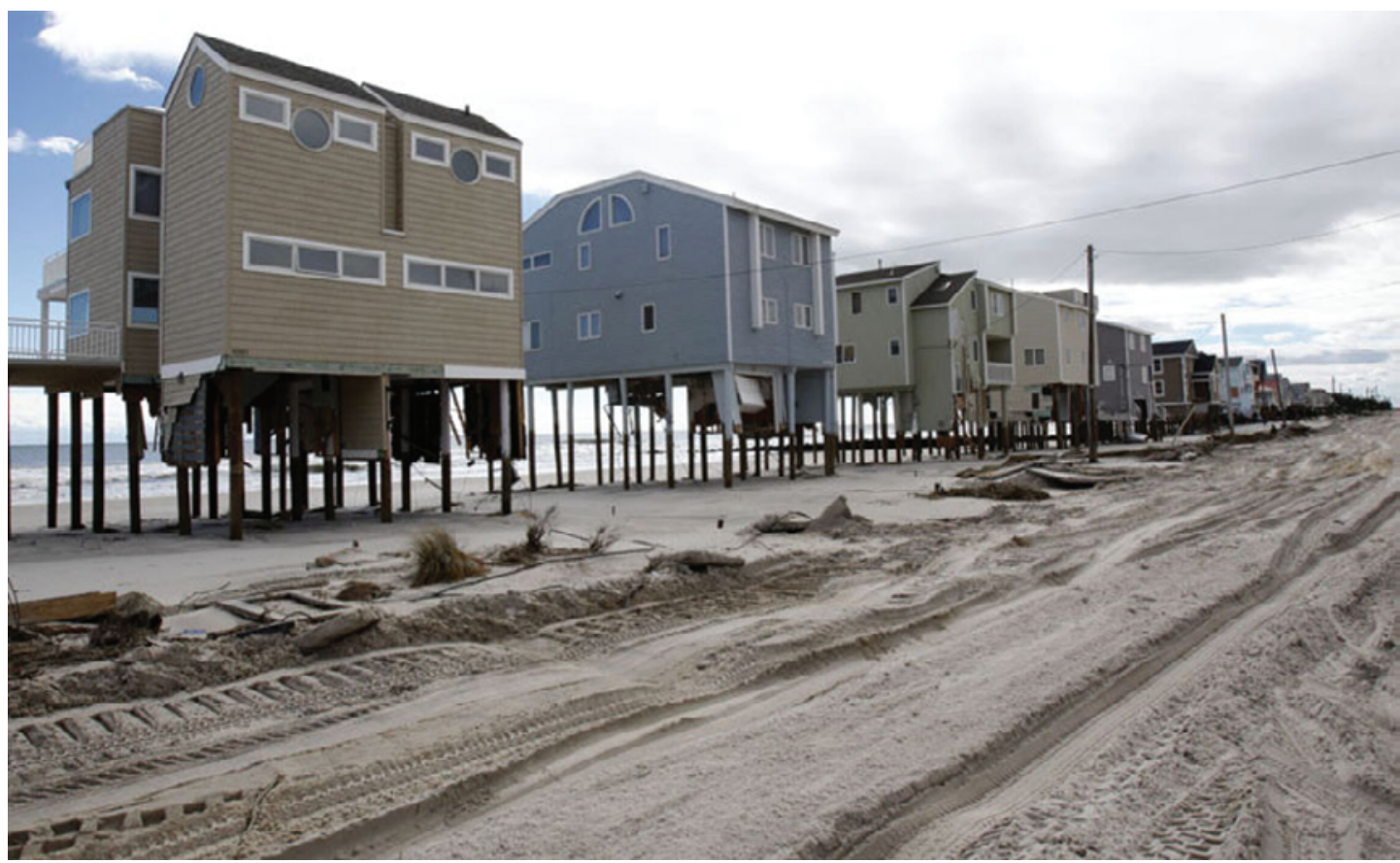

A row of beach homes damaged by Hurricane Sandy in the Holgate section of Long Beach Island, NJ. Photo taken October 31, 2012. (Photo courtesy of The Star-Ledger, photographer Noah K. Murray)

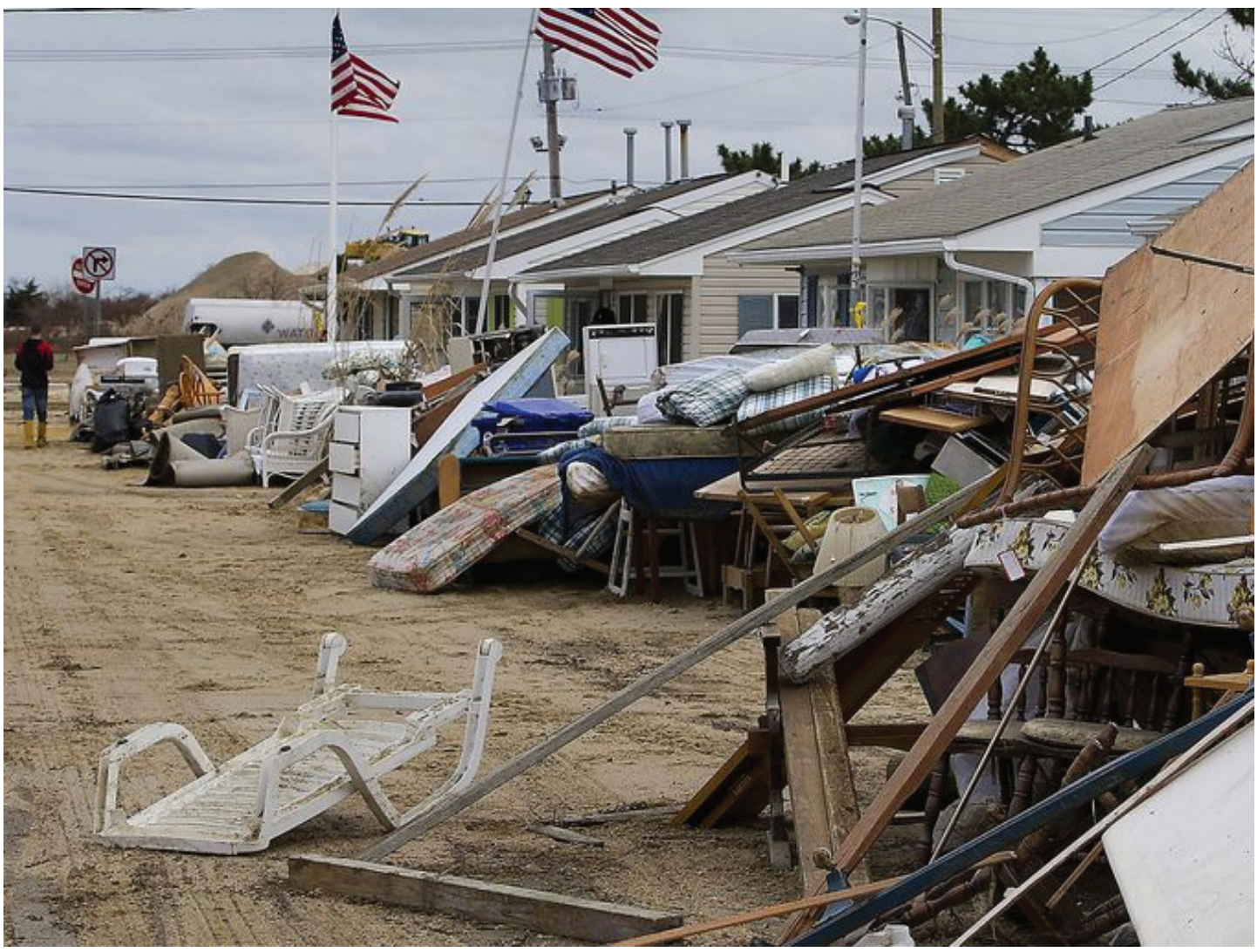

A road filled with debris in Ortley Beach, N.J, after residents were allowed to get back to their homes to clean up after Hurricane Sandy. Photo taken November 14, 2012. (Photo courtesy of the Asbury Park Press, photographer Peter Ackerman) 
$A$

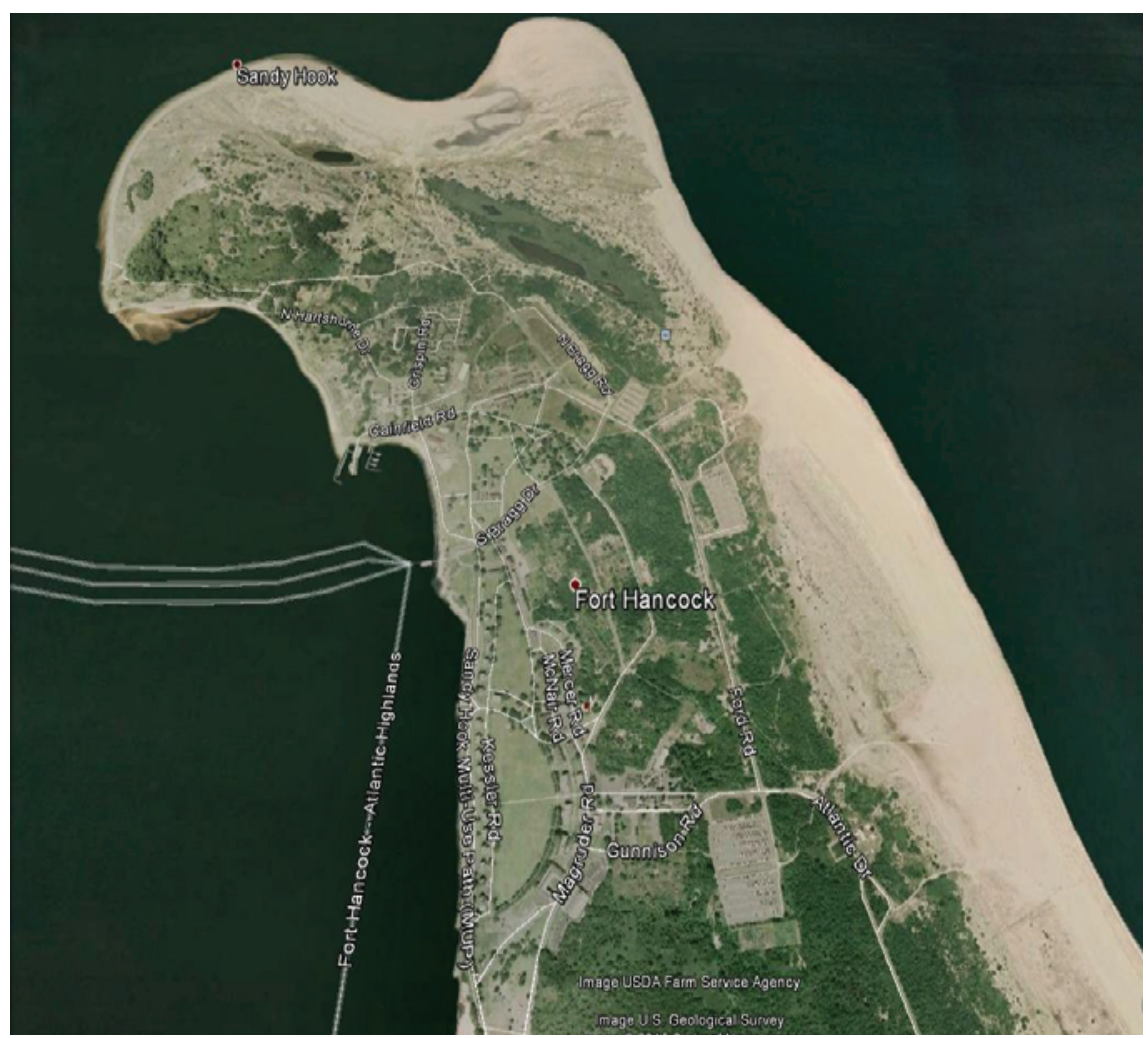

$B$

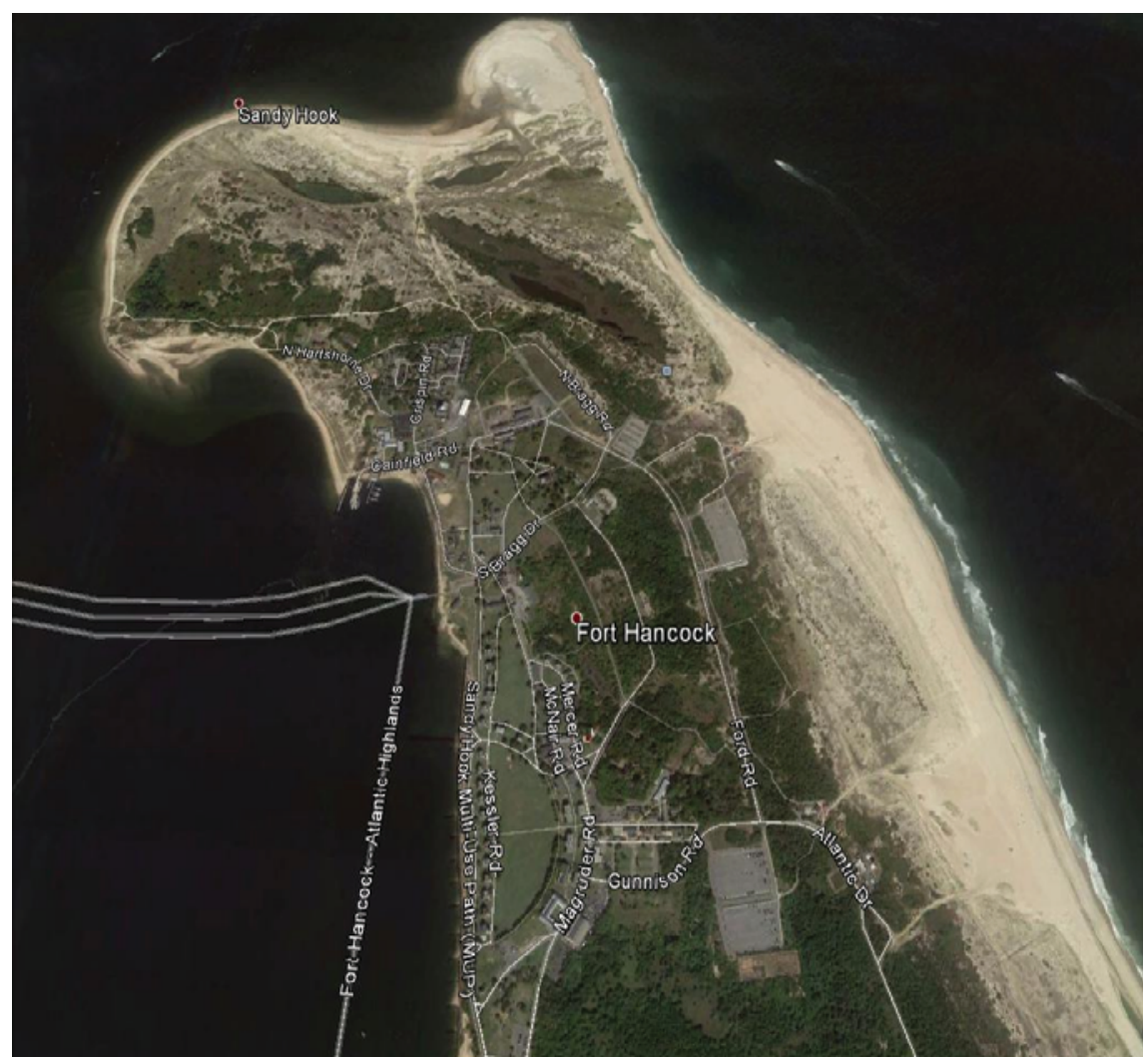

Aerial Images of Sandy Hook, NJ, A, taken in 2007, B, taken in 2010, and C, taken after Hurricane Sandy in November 2012. (Photos courtesy of NASA Earth Observatory) 


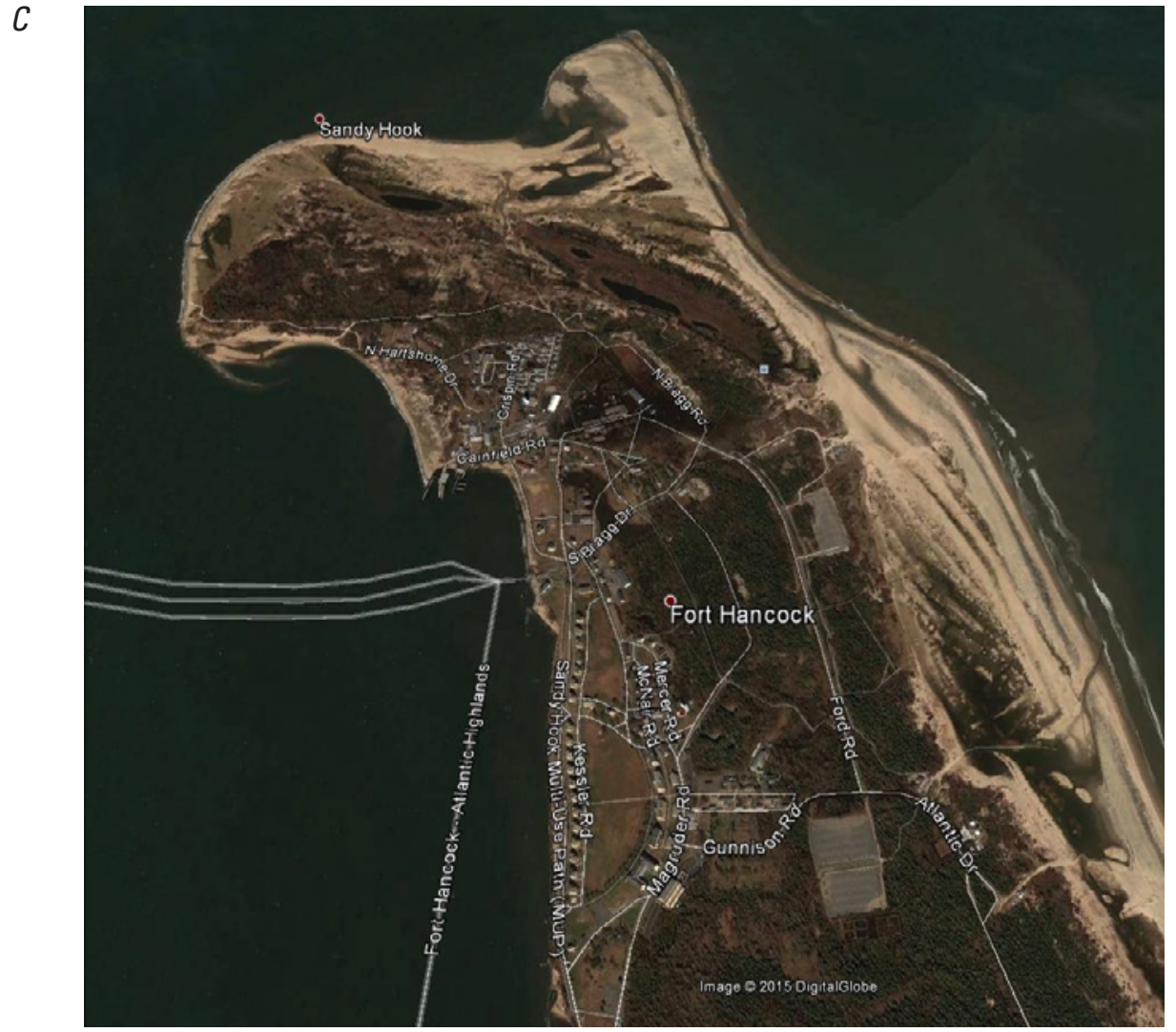

Aerial Images of Sandy Hook, NJ, A, taken in 2007, B, taken in 2010, and C, taken after Hurricane Sandy in November 2012. (Photos courtesy of NASA Earth Observatory)-Continued 


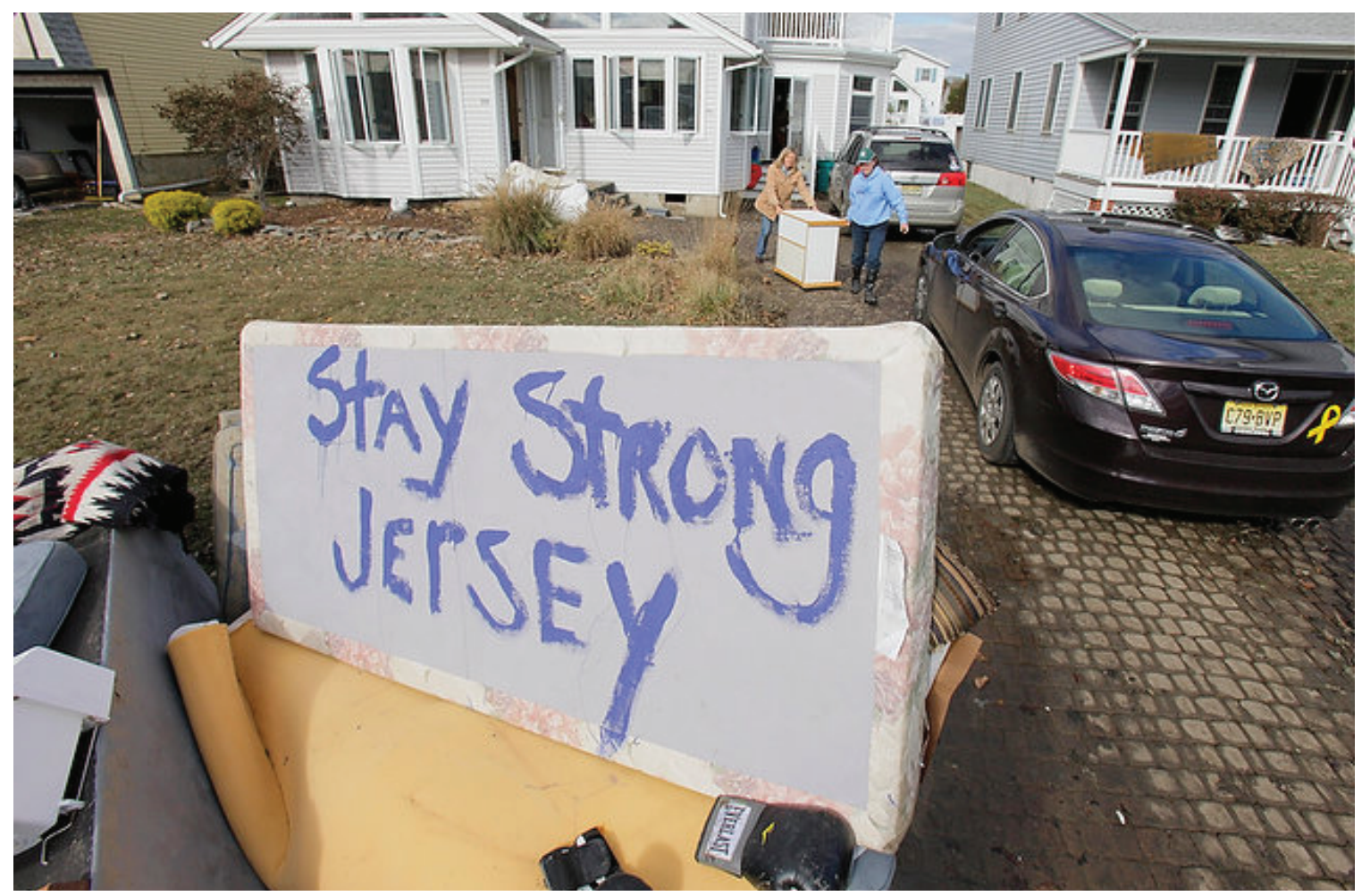

Home owners in Point Pleasant, NJ, offer a message to residents of New Jersey affected by Hurricane Sandy. Photo taken November 3, 2012. (Photo courtesy of The Star-Ledger, photographer Tony Kurdzuk)

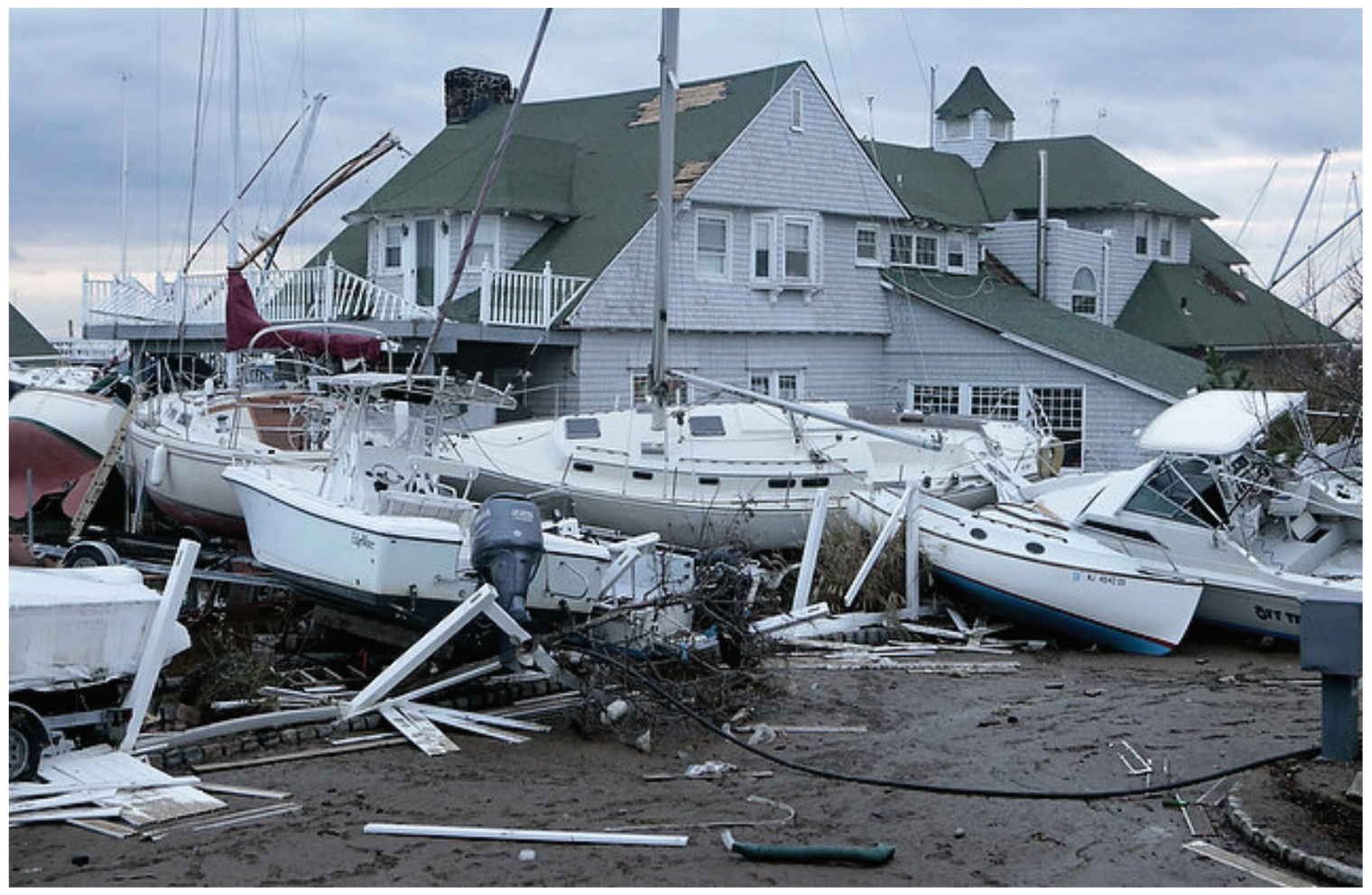

Boats stacked on top of each other in Sea Bright, NJ, after Hurricane Sandy caused major damage to the New Jersey coast. Photo taken November 1, 2012. (Photo courtesy of The Star-Ledger, photographer Aristide Economopoulos) 


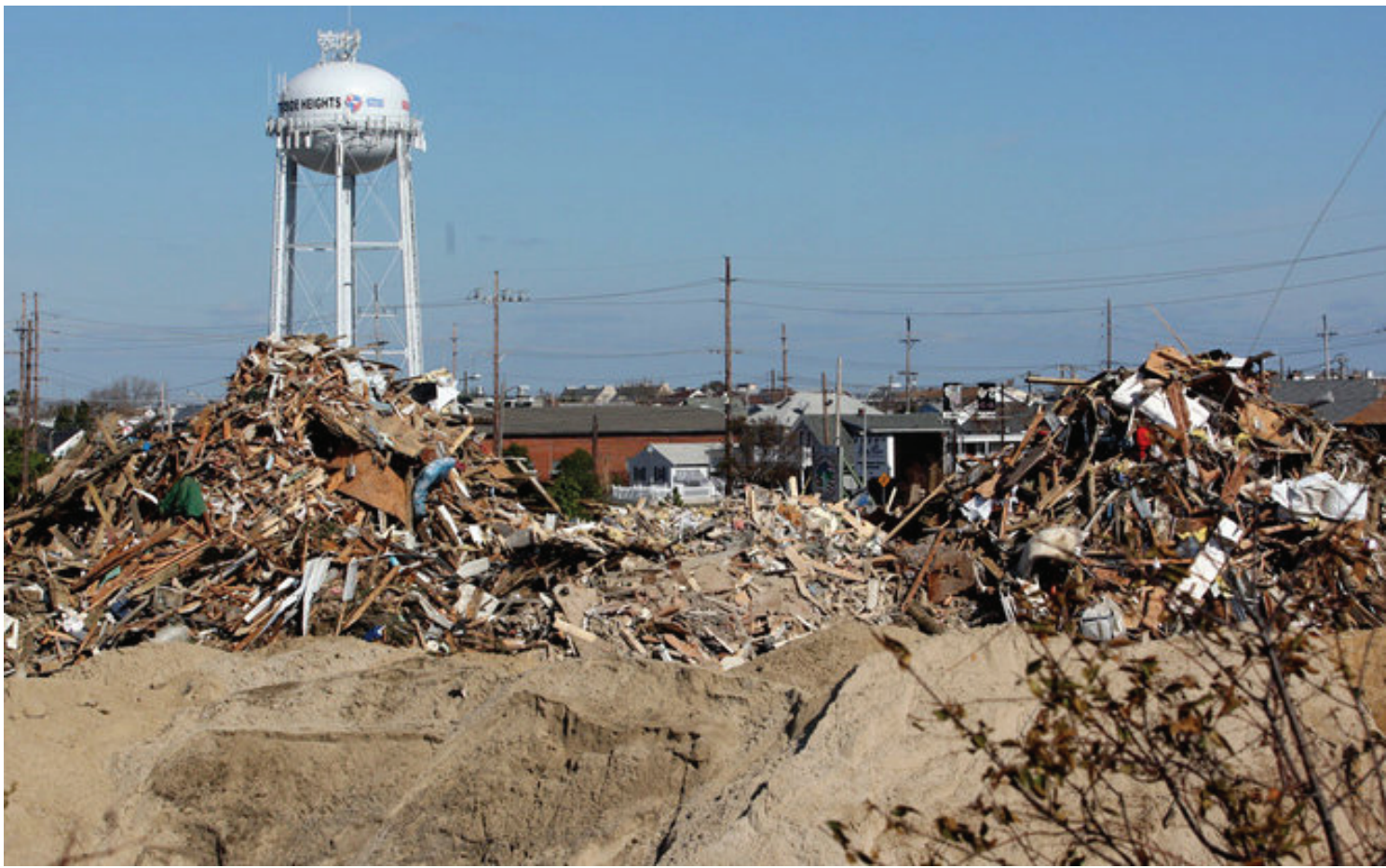

Debris pile near the Seaside Heights, NJ, water tower from initial cleanup efforts after Hurricane Sandy caused major damage to many coastal communities. Photo taken November 5, 2012. (Photo courtesy The Star-Ledger, photographer David Gard)

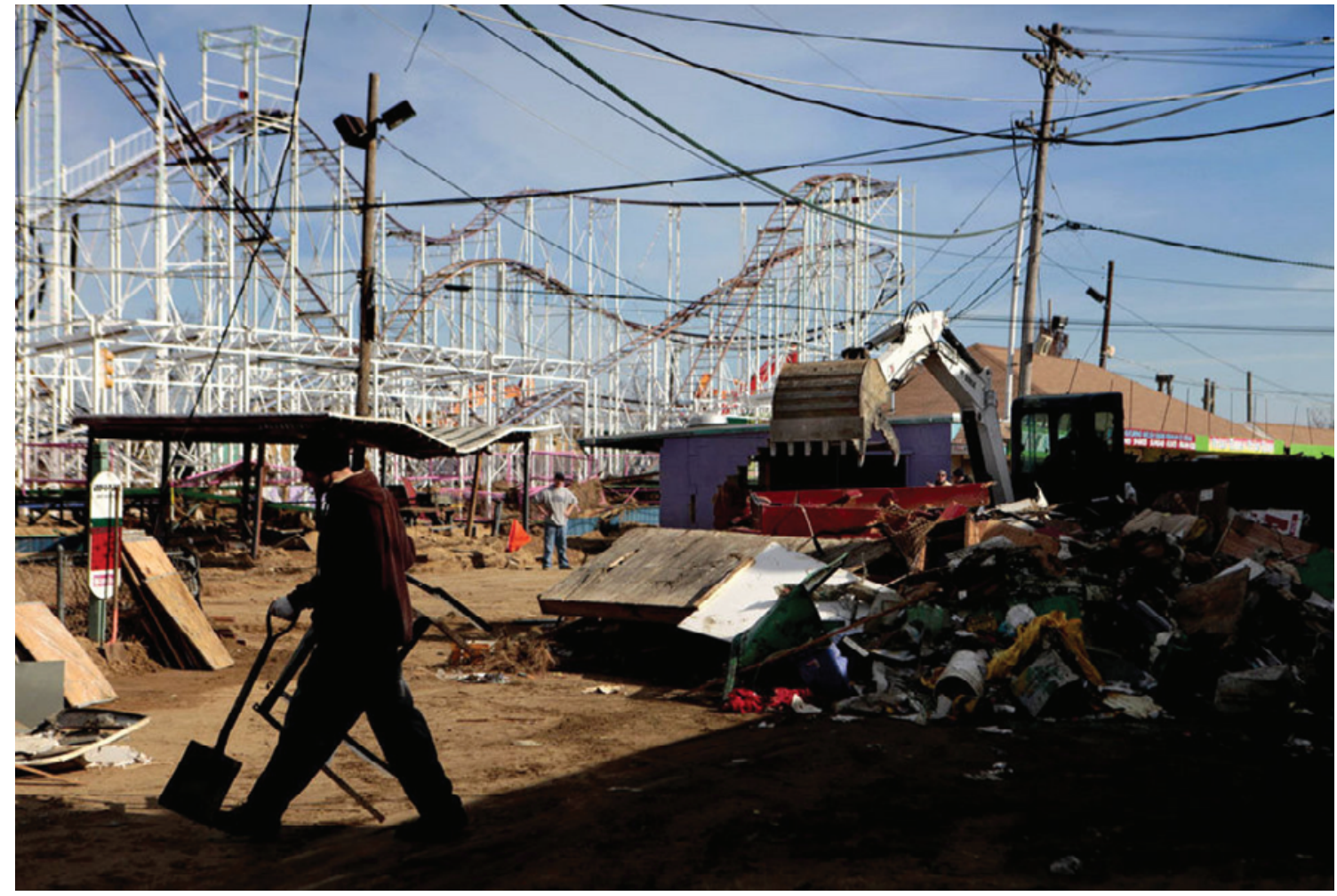

Keansburg Amusement Park, NJ, sustained major damage from Hurricane Sandy. Photo taken November 6, 2012. (Photo courtesy of The Star-Ledger, photographer Aristide Economopoulos) 

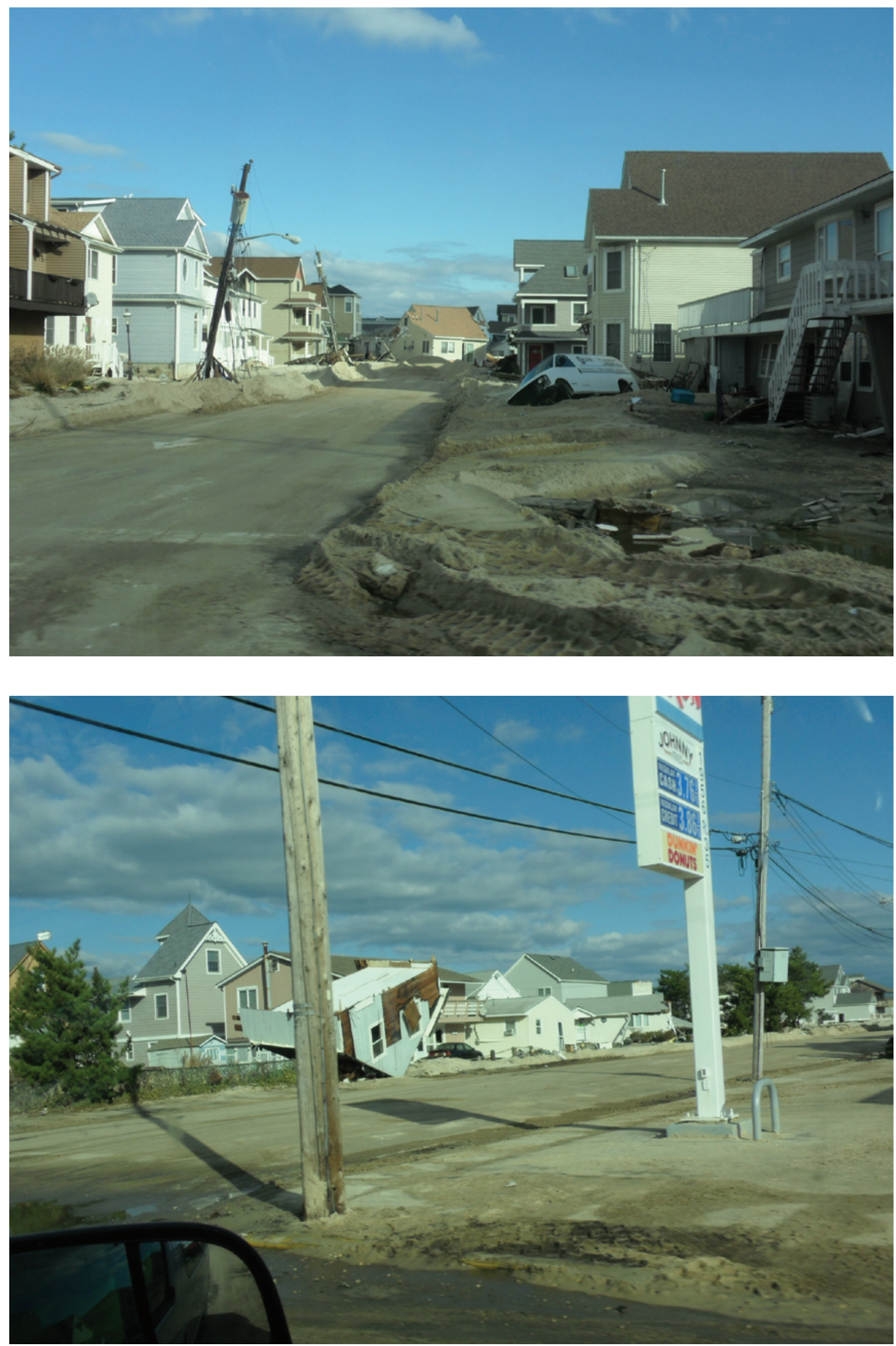

Many homes in Seaside Heights suffered major damage during Hurricane Sandy. Photos taken November 4, 2012. (Photos by Andrew Ebner, USGS) 

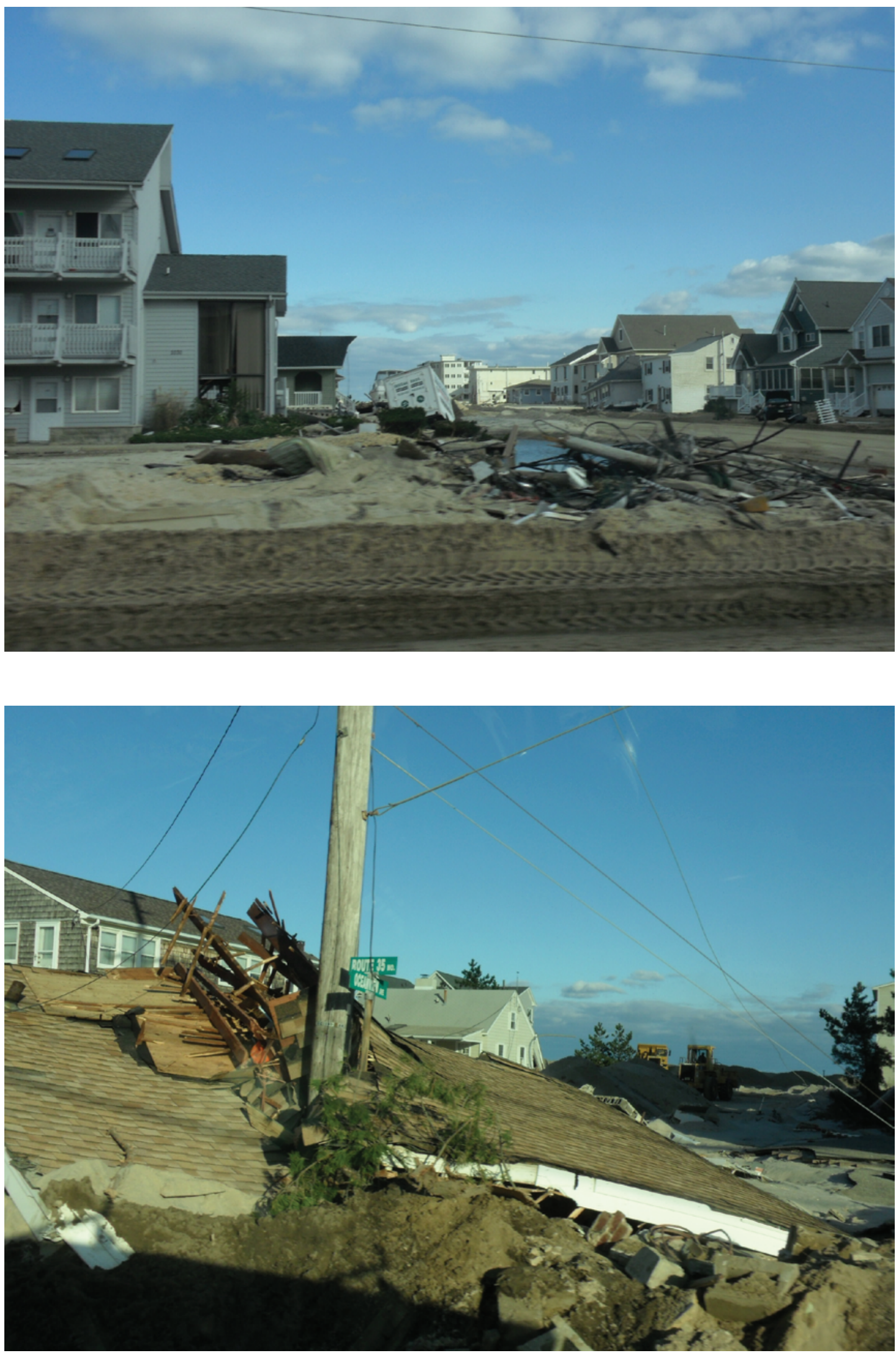

Many homes in Seaside Heights, NJ, were completely destroyed during Hurricane Sandy. Photos taken November 4, 2012. (Photos by Andrew Ebner USGS) 


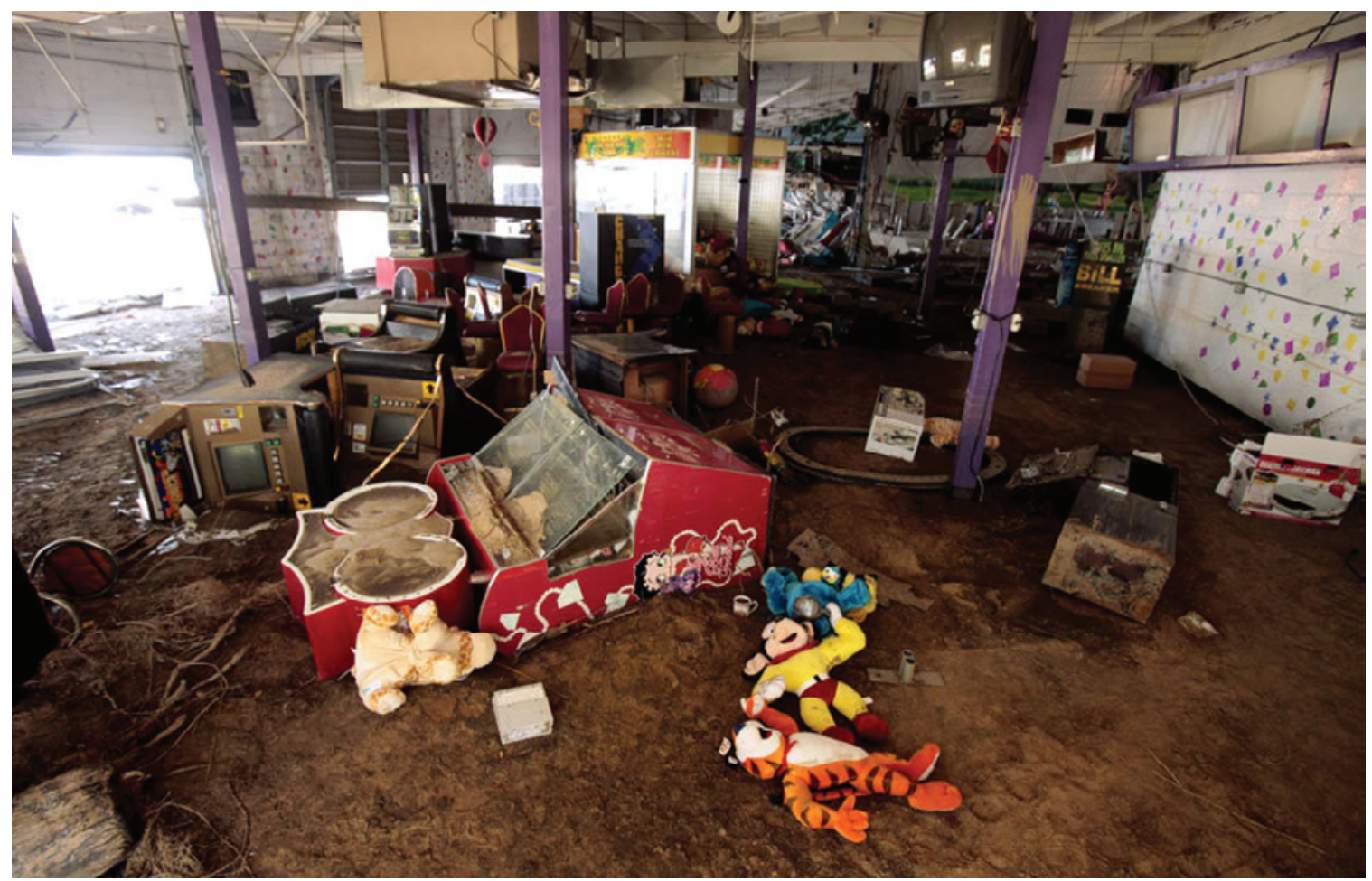

Keansburg Amusement Park, NJ, sustained major damage from Hurricane Sandy. Photo taken November 6, 2012. (Photo courtesy of The Star-Ledger, photographer Aristide Economopoulos)

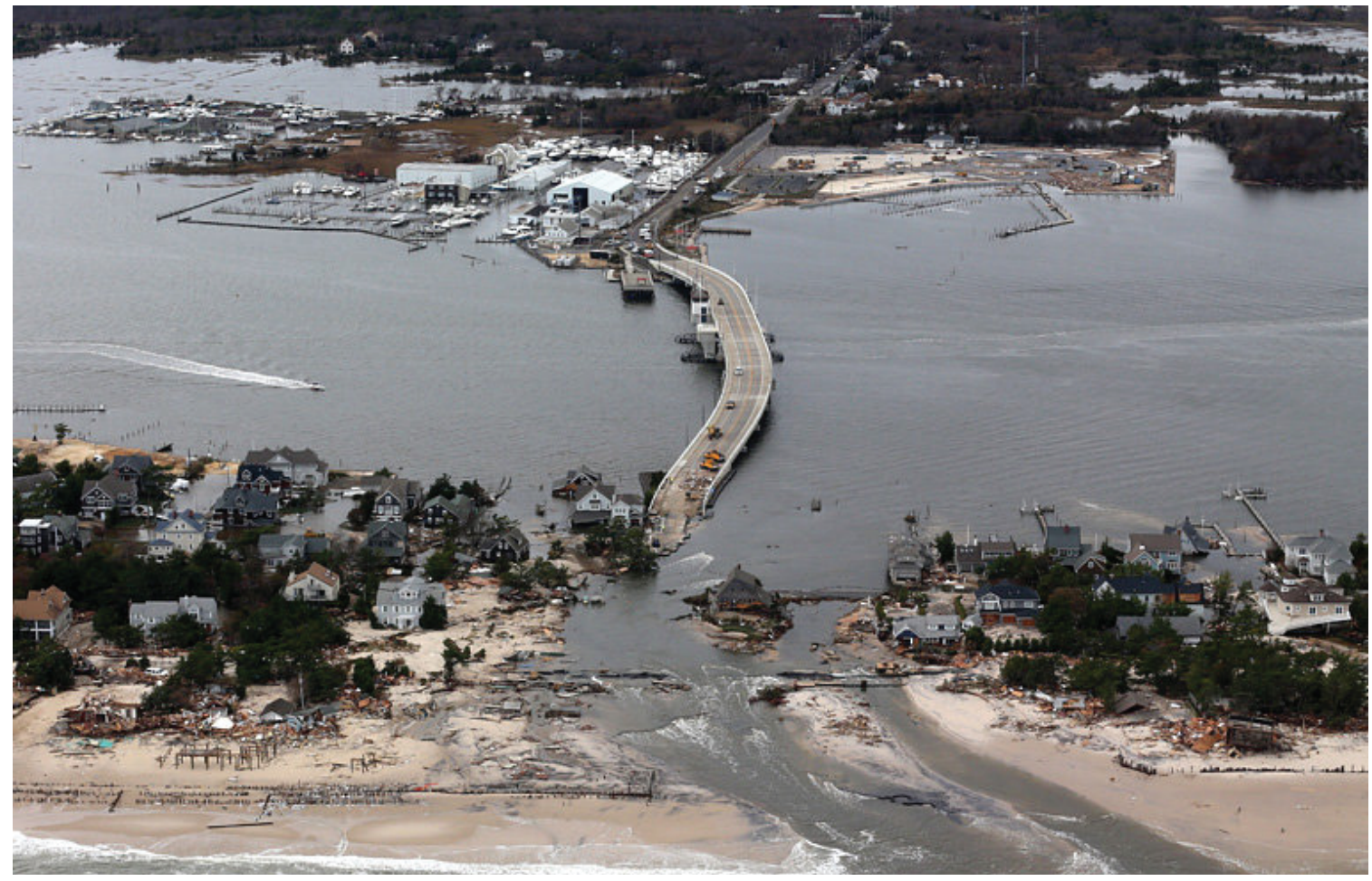

Storm surge from Hurricane Sandy breached the barrier island at Mantoloking, NJ, and severely damaged Route 35 bridge over Barnegat Bay. Photo taken November 2, 2012. (Photo courtesy of The Associated Press, photographer Doug Mills) 
$A$

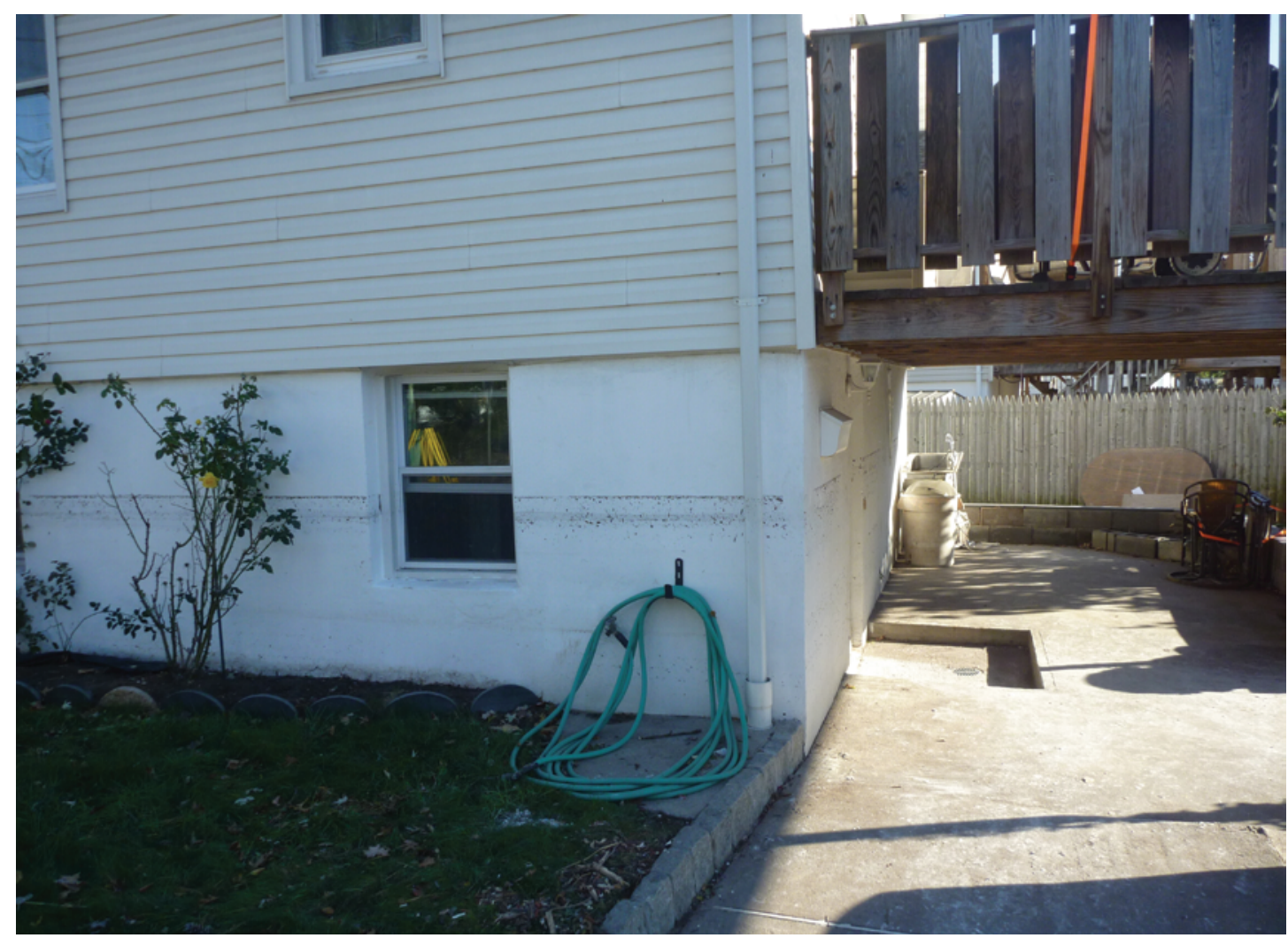

$B$

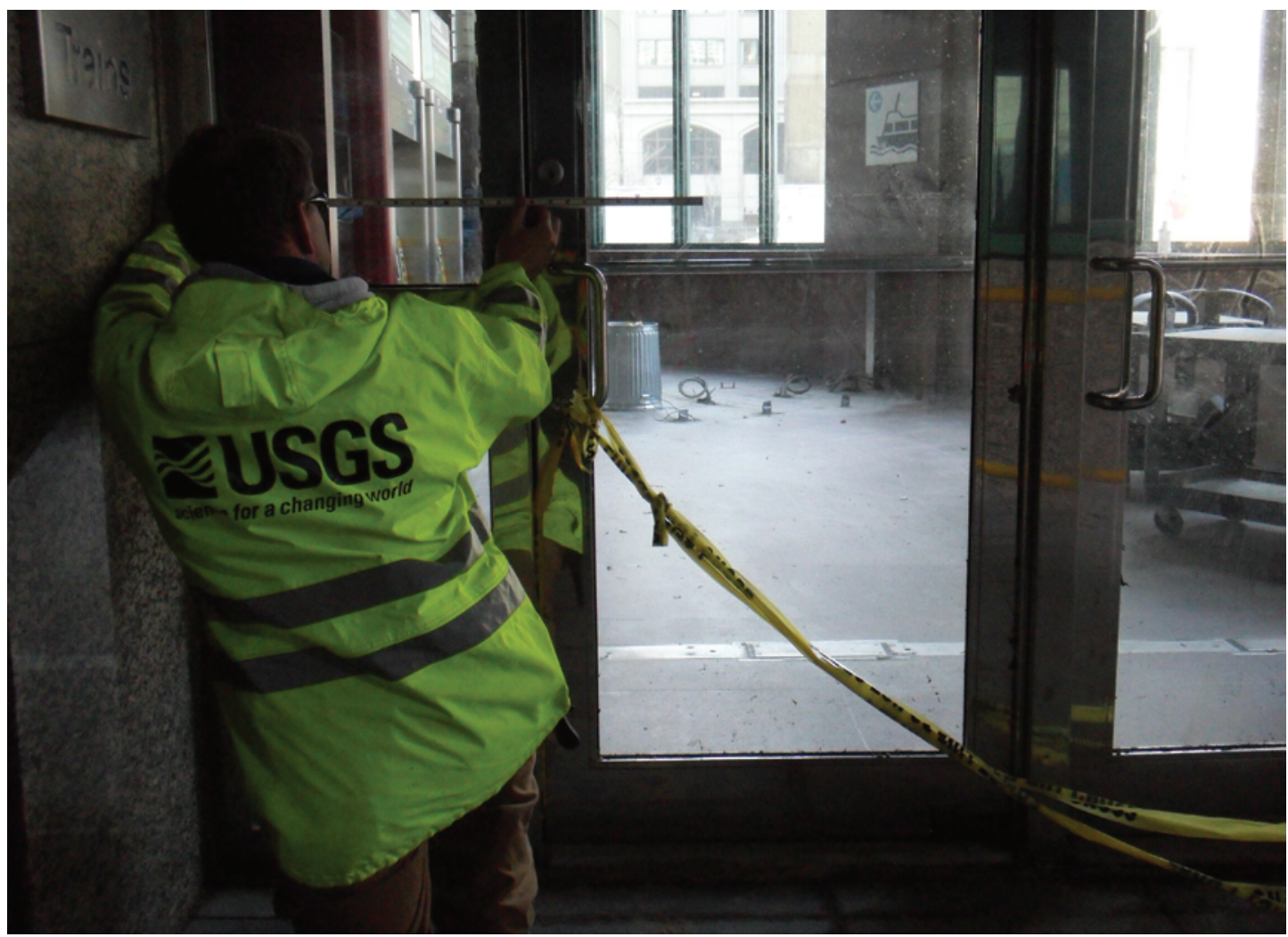

High-water marks (mud lines) on A, house on Eckel Road in Bergen County, NJ, B, door of entrance to Port Authority Transit Hub (PATH) building in Hudson County, NJ, show the depth of inundation at these locations from coastal flood waters resulting from Hurricane Sandy. Photographs taken November 14, 2012. (Photograph $A$ by Jon Lageman and $B$ by Crystal Hammer, USGS) 

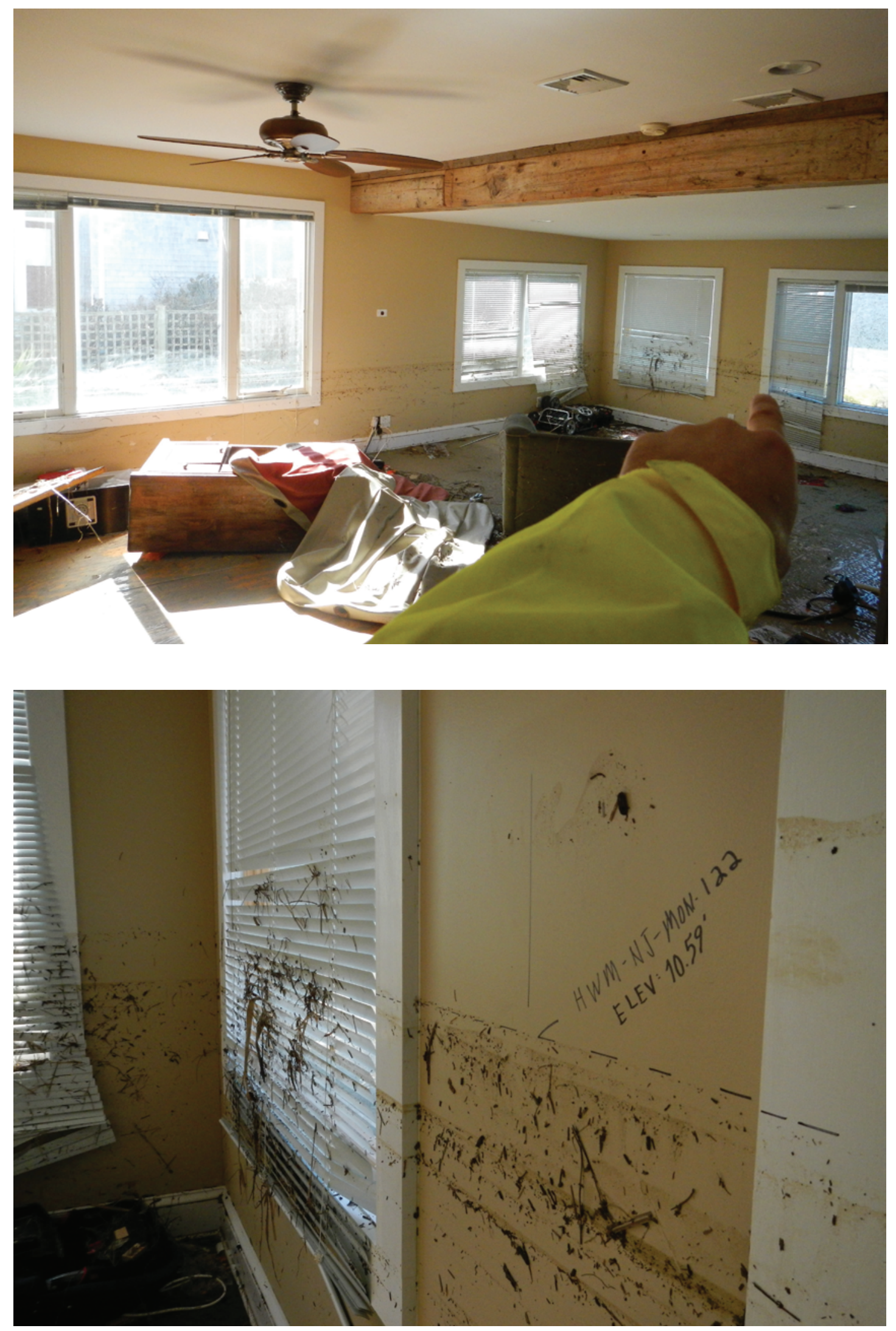

High-water marks (mud/debris lines) on the inside of house on Ocean Ave. in Monmouth County, NJ, show the depth of inundation in this house by coastal flood waters resulting from Hurricane Sandy. Photographs taken November 14, 2012. (Photos by Dan Stephens, USGS) 


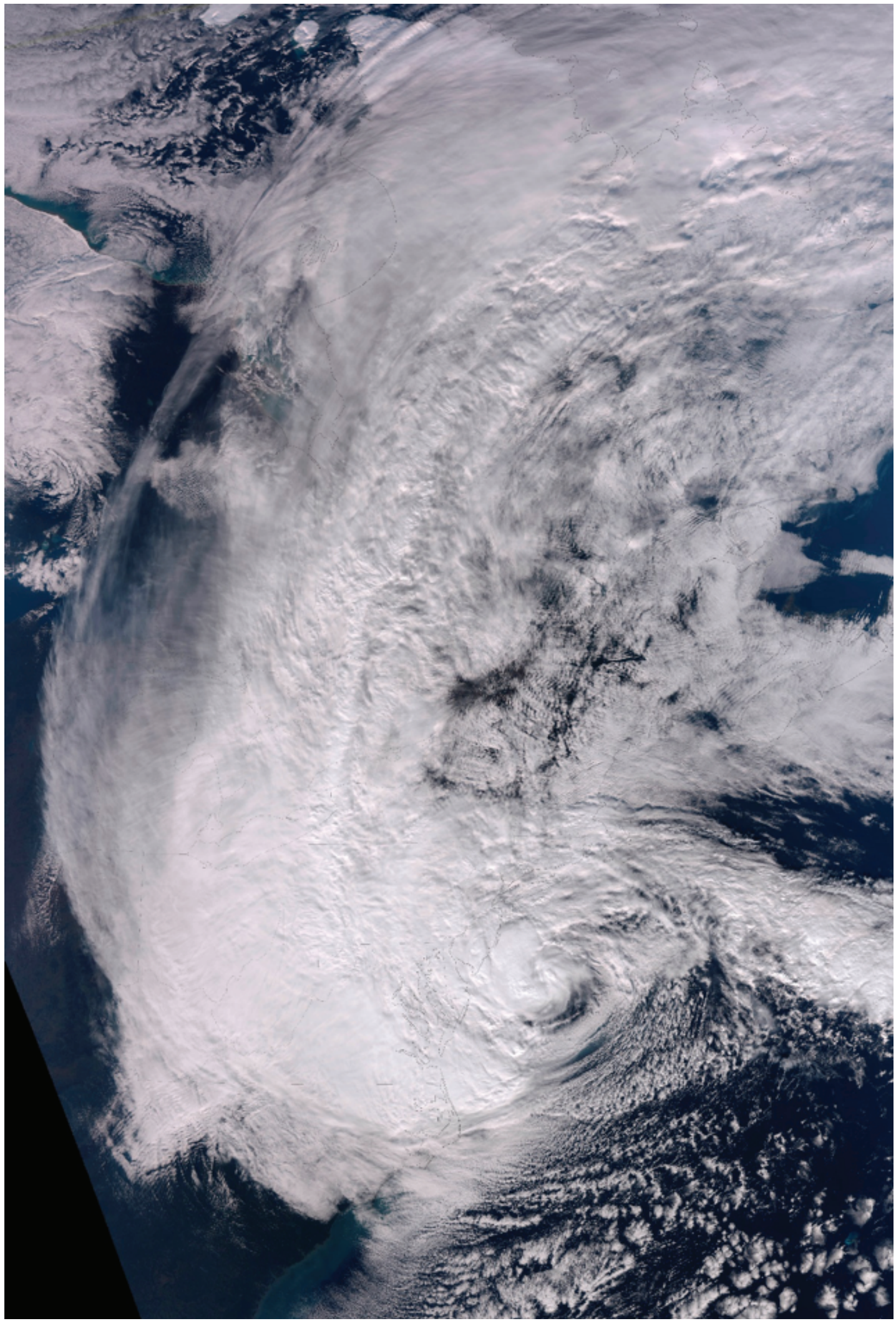

On October 29, 2012, Hurricane Sandy approached the densely populated East Coast of the United States. The Visible Infrared Imaging Radiometer Suite (VIIRS) on the Suomi NPP satellite acquired this natural-color image of Sandy at 1:35 p.m. Eastern Daylight Time (17:35 Universal Time) on October 29, 2012. (Photo courtesy of NASA Earth Observatory) 


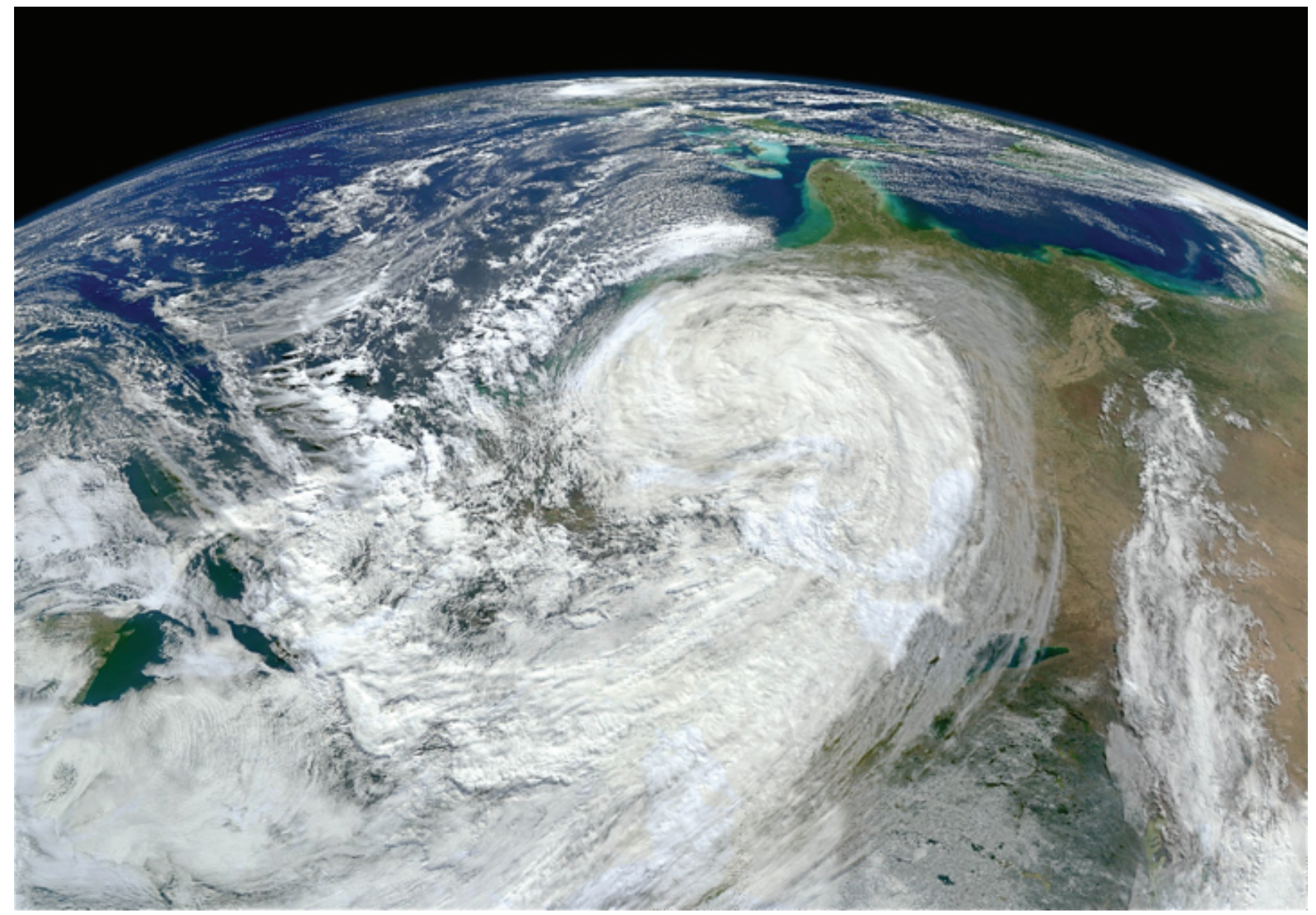

As Hurricane Sandy moved north along the East Coast of the United States, its waves churned up sediments from the continental shelf and left turbid water in its wake. By midday October 30, 2012, the skies over coastal Florida, Georgia, and South Carolina had cleared enough to reveal that turbidity to the Visible Infrared Imaging Radiometer Suite (VIIRS) on theSuomi NPP satellite. (Photo courtesy of NASA Earth Observatory) 

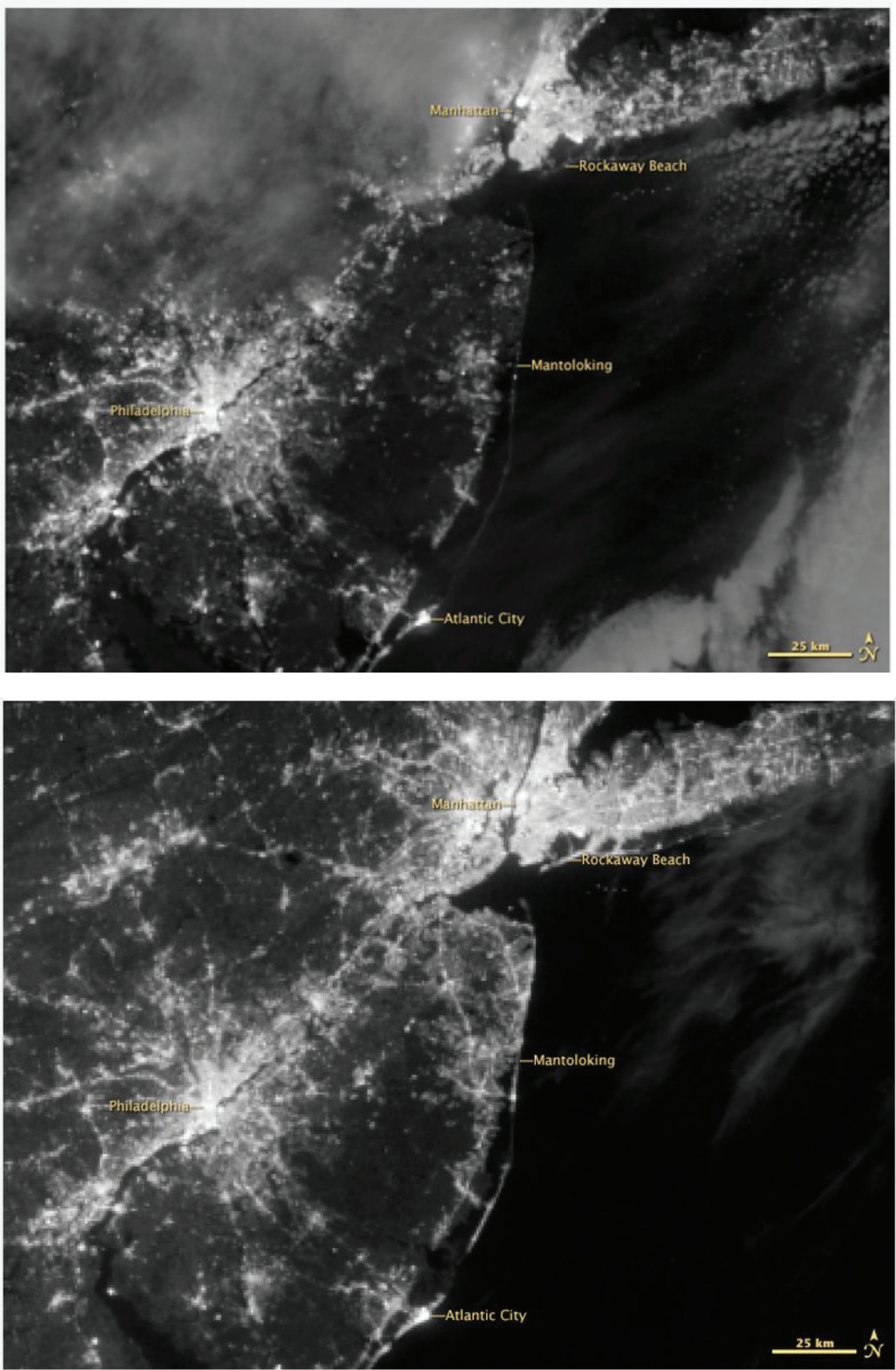

Images show New Jersey, New York, and eastern Pennsylvania as viewed at night by the Visible Infrared Imaging Radiometer Suite (VIIRS) on the Suomi NPP satellite. The top image was taken at 2:52 a.m. Eastern Daylight Time (06:52 Universal Time) on November 1, 2012. The lower image was taken at 2:14 a.m. Eastern Daylight Time (06:14 UTC) on August 31, 2012, when conditions in the area were normal. (Photographs courtesy of NASA Earth Observatory) 
Publishing support provided by the

U.S. Geological Survey Science Publishing Network, West Trenton Publishing Service Center

For more information concerning the research in this report, contact: Director, New Jersey Water Science Center

U.S. Geological Survey

3450 Princeton Pike, Suite 110

Lawrenceville NJ, 08648

http://nj.usgs.gov/ 
